

4 (

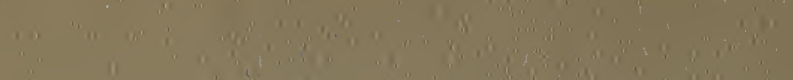

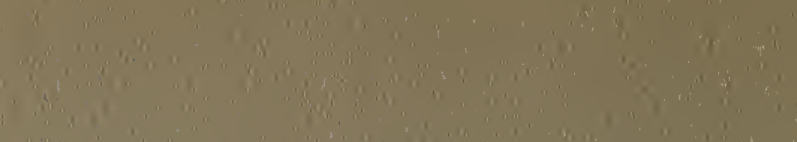

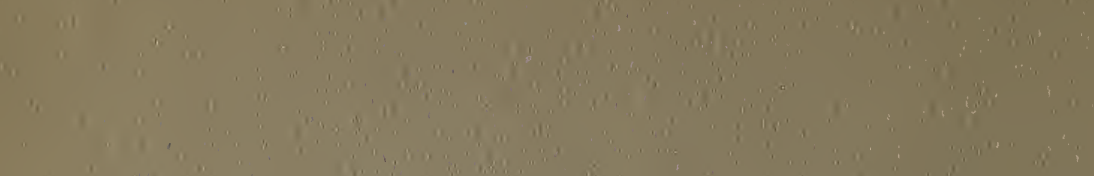

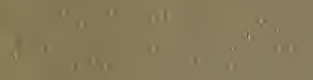

A.

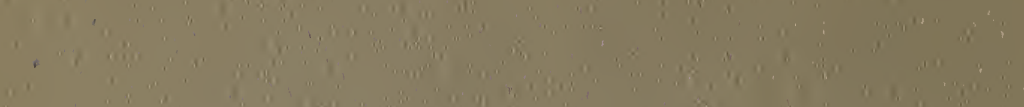

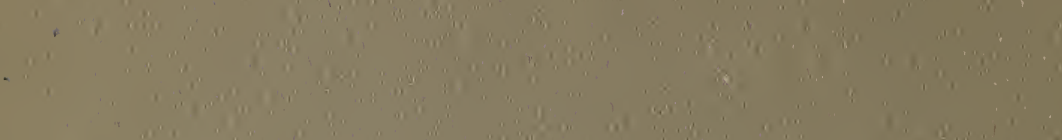

and (n) (n) (n)

(n) (n) (n)

1.

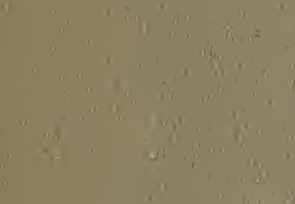

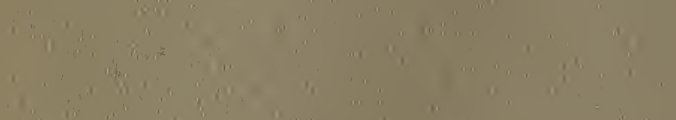
(n) (n)

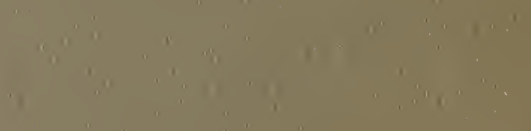
(1) 1

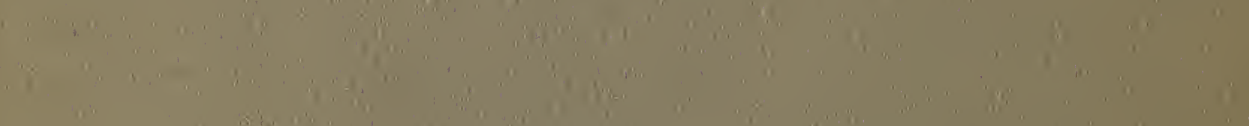

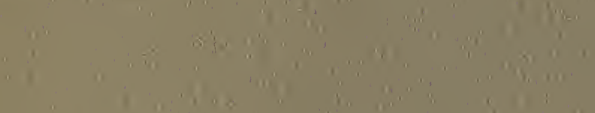

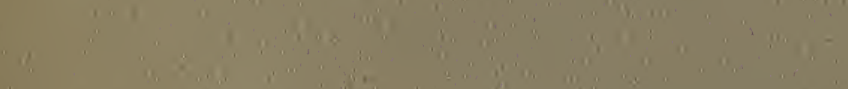

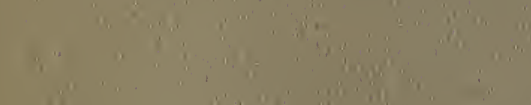
Q ...

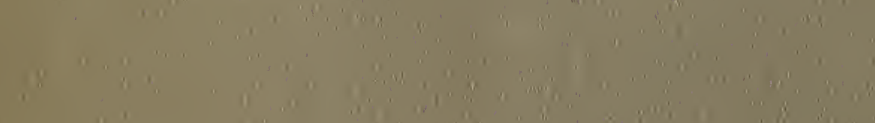

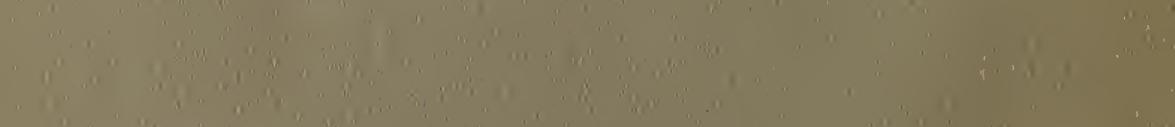
*

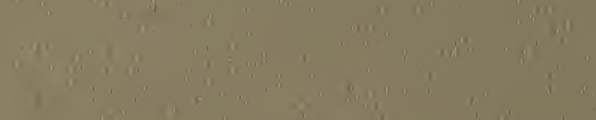

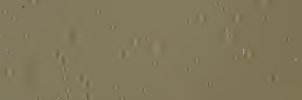

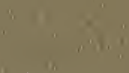
$1:$

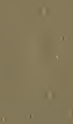
in

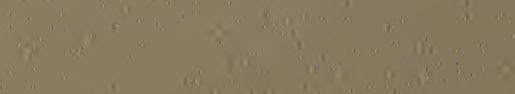
. Q

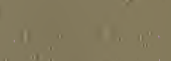
in , 10.

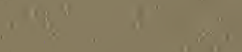

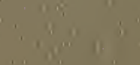

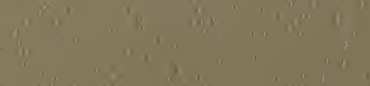

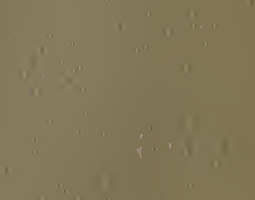
of Fi 10. 

Field Museum of Natural History

Publication 192

Anthropological Series

Vol. XV, No. 2

\title{
THE BEGINNINGS OF PORCELAIN IN CHINA
}

\author{
BY \\ Berthold LaUfer \\ Curator of Anthropology
}

With a Technical Report by H. W. Nichols Assistant Curator of Geology

Twelve Plates and Two Text-Figures

The Mrs. T. B. Blackstone Expedition

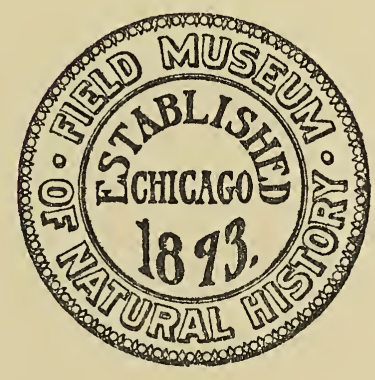

Chigago

I9I 7

Fraer Gall
Washington, $0 . \mathrm{C}$ 



\section{CONTENTS}

INTRODUCTORY

Report on a Technical Investigation of Ancient Chinese

Pot Tery, By H. W. Nichols

I. Porcelanous Han Pottery . . . . . . . . . 86

II. Analysis of a Green Glaze from a Bowl of Han

Pottery . . . . . . . . . . . . . . . . 92

Historical Observations and Conclusions . . . . . . 95

Historical Notes ON KaOLIN . . . . . . . . . . . IIO

The Introduction of Ceramic Glazes into China, with

Special Reference to the Murrine Vases . . . I20

The Potter's Wheel . . . . . . . . . . . . . 148

INDEX . . . . . . . . . . . . . . . . .178 



\section{The Beginnings of Porcelain in China}

\section{INTRODUCTORY}

In February of I9Io, while in Si-ngan fu, the capital of Shen-si Province, the writer received from Mr. Yen, a Chinese scholar and antiquarian of note with whom he was on very friendly terms, a curious bit of ancient pottery, which at first sight bore all the characteristic marks associated with what is known as Han pottery, but which, on the other hand, exhibited a body and a glaze radically different from that ware (Plate I). Mr. Yen accompanied the object with a written message, explaining the circumstances under which it had been found, and commenting to some extent on its historical value. Following is a literal rendering of his letter: "I once heard dealers say that they had seen 'Han porcelain' (Han ts'e 谨 磁), but I had no faith in this statement. In the winter of the year ting wei 丁未 未 (1907) I secured a large vase, and suspected that it might be an object of the Han period, but did not dare to be positive about this point. In the spring of last year some one brought to light, from a Han grave which he had excavated, ancient jade pieces and such-like things, together with an enormous iron cooking-stove. On the latter are found, cast in high relief, six characters reading, 'Great felicity! May it be serviceable to the lords!' ( $t a$ ki chiang $i$ hou wang 大吉昌宜侯王). On the top of this stove was placed a small 'porcelain jar.' I lost no time in sending out an agent to effect a purchase, but the stove had already passed into the hands of a merchant. So I obtained only the 'porcelain jar' in question, the material and style of which proved identical with those of the large vase purchased by me years ago. For this reason I now felt positive that the question is here of 'Han porcelain.' Subsequently I acquired also a jar of the type styled le $i$ 触, and big and small vases; in all, four. From that time the designation 'Han porcelain' began to be established in the world.

“Written in Ch'ang-ngan by Yen Kan-yüan 閻甘園 on the day when the flowers sprout forth (百花生日), of the second month of the second year of the period Süan-t'ung (February 27, I910)."

While I had a deep respect for Mr. Yen's learning and extensive knowledge of archæological subjects, I remained sceptic as to the

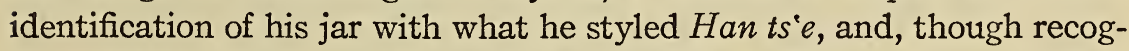
nizing its intrinsic merit as a piece of evidence filling a lacune in our 
knowledge of ancient pottery, I did not allow myself to be carried away by the usual wave of enthusiasm over a first discovery (since then six years and a half have elapsed), but decided to hold the matter in abeyance till a thorough analysis, to be made at home, would permit us to base an opinion on facts. Meanwhile oppurtunities were seized at Si-ngan fu to collect as much as possible of this novel pottery. My first concern, naturally, was to secure the large iron stove mentioned in Mr. Yen's missive. A desire thus expressed spreads in that quaint old town like a prairie-fire; and when the sun had risen and set again, I was the lucky owner of that precious relic. Indeed, Yen's description was by no means an exaggeration. In type and style, this castiron stove (Plate II), partly in decay and the iron core having entirely rotted away, exactly corresponds to the well-known Han burial cookingstoves, and it is the finest specimen of ancient cast-iron that I was able to find. Being posed on four feet in the form of elephant-heads, it is built in the shape of a horse-shoe, and provided with a chimney at the rounded end, five cooking-holes, and a projecting platform in front of the fire-chamber. On the latter is cast an inscription in six raised characters, which read exactly as indicated by Mr. Yen, - a formula typical of the Han and earlier ages, and encountered on many bronze vessels. The style of these characters is in thorough agreement with that of Han writing. The object was discovered in a grave near the village Ma-kia-chai 馬家寨, $5 l i$ north of the town Hien-yang, in Shen-si Province. As previously remarked, ${ }^{1}$ without laying down any hard and fast rules, there is a great deal of probability in assigning such cast-iron objects to the period of the Later Han (A.D. 25-220), while it is equally justifiable to extend the time of their manufacture over the entire third century of our era. The iron stove thus furnishes a clew to the date of the jug which was found in the same grave with it. Needless to say, I left no stone unturned, and kept on inquiring and hunting for this so-called $\mathrm{Han} \mathrm{ts}^{\circ} e$ ware in and around Si-ngan. I succeeded in bringing together only eight more pieces (Plates III-X), among these the vessel lei referred to in Yen's memorable epistle, ${ }^{2}$ and a number of larger fragments and small shards, which are always precious and encouraging acquisitions to the archæologist, as they are not under suspicion, and offer welcome study material.

1 Chinese Clay Figures, p. 216.

2 The pottery vase of this designation is mentioned in the Chou $l i$ as holding the sacrificial spirits called ch'ang, which were offered to the deity Earth (BIOT, Tcheou-li, Vol. I, p. 468). It is the reproduction in clay of an original bronzetype, frequent among the bronze vessels of the Chou. 
It will be noticed that these nine bits, in their forms and decorations, decidedly agree with the mortuary Han pottery, ${ }^{1}$ and that, taken merely as ceramic types, they represent archaic types of Han art. On the other hand, however, apart from their technical composition, they have in common some characteristic features which are not found in Han pottery. To these belong the curious loop handles, obviously imitative of a knotted rope or a basketry handle, and the geometric wave patterns. The latter, it will be remembered, occur also in the relief bands on many vases of Han pottery, but are of a different style, in the manner of realistic waves. There is in our collection only one unglazed, gray Han pottery vase with a geometric wave design approaching that in the above group; but it is a much bolder and freer composition, and not so neat and refined as in the porcelanous vases. Even in some shapes, the traditional rules of the Han may not be quite strictly observed; they may be less stern and rigorous, and, while dignified and partially imposing, treated with somewhat greater individual freedom. This, however, is rather a point of sentiment or impression than a ponderable argument. The deviations from the standard Han pottery are insignificant when contrasted with what the two groups have in common. The best tradition and spirit of Han art are preserved in these nine productions.

The comparative scarcity of this ware is notable, and gives food for serious reflection. As the writer was able to secure on his last expedition for the Field Museum many hundreds of pieces of Han pottery of all types and descriptions, while several thousand specimens have passed through his hands during the last fifteen years, and as he could hunt up only nine representatives of this novel (porcelanous) ware, these numbers may be regarded as the relative (certainly not absolute) proportions in which the two classes of pottery are to be found, and, we may add, were made in the past. Two inferences may be drawn from this phenomenon,- this peculiar ware was the product of only a single kiln or of very few kilns; and these kilns did not flourish during the Han period, but either at its very close, or even, and more probably, toward the middle or end of the third century. This point will be more fully discussed hereafter.

${ }^{1}$ In speaking of Han pottery, it should be understood that in this case the term "Han" does not refer to the chronologically exact boundaries of a dynastic period, but to an archæological epoch, a certain phase of ancient Chinese art, which is not necessarily gauged by the dates 206 B.C. and A.D. 220. There is naturally an overlapping at both ends, and we have, at least for the present, no means of determining exactly either the beginning or the end of Han art. This much seems certain, that the middle and the latter part of the third century A.D. have thoroughly remained under the influence of Han tradition. 
On my return to America, two objects remained to be pursued in connection with this new material,- first, to secure the co-operation of a competent investigator for a chemical analysis of the body and glaze of this pottery; and, second, to search in other museums for corresponding specimens. My colleague Mr. Nichols, assistant curator of geology in the Field Museum, volunteered to undertake the technical task, and he has carried it out with rare devotion and perseverance. His experiments were conducted, and his results were obtained, in I9I2. From the date of our publication it will be seen that we were not in a hurry to bring it to the notice of the world. We allowed it to rest and to mature, and discussed the new problems with each other and with ceramic experts at frequent intervals. Their friendly interest and advice at last encouraged us to make known the results of our research, which we trust will be of some utility to students interested in the history of Chinese pottery.

In regard to kindred objects in other collections, I have been able to obtain the following information. Mr. Francis Stewart Kershaw of the Museum of Fine Arts, Boston, Mass., who saw the pieces of pottery in question in the Field Museum, mentioned to me that similar specimens were in the Boston Museum. On sending him some fragments from our material for comparison with that under his care, he wrote as follows: ${ }^{1}$

"The bits of potsherd are quite large enough to tell me their story, and I am very much obliged for them. Except in hardness, they are similar to the clay of three of our pieces, being of the same color, texture, and apparent constituents. Two of our pieces were bought in China by Mr. Okakura, and both were labelled 'Sung' by some Chinese (probably a dealer). Okakura called one (I 2875) which is covered with a blackish shaded gray-green glaze, opaque and dull, 'Sung.' The second ( 12865 ), which is precisely similar in potting, clay, and glaze, to your Han porcelanous jars, Okakura called 'T'ang.' Mr. Freer, by the way, has a vase like $\mathrm{r} 2865$, which he calls 'T'ang.' The third of our pieces (I2II8) was bought from Mr. C. F. Gammon (formerly a lieutenant in the United States Army), who obtained it in Nanking from a cooly, who had unearthed it while digging in a railway cutting in Nanking. The jar was partly full of coins, all alike, of the denomination 'pan liang' 牛雨, issued in 175 B.C. in the reign of the

1 The letter is published here with Mr. Kershaw's consent.

2 This object was exhibited in the National Museum of Washington in I9I2, when a selection from the Freer Collection was temporarily shown. I then had occasion to see it. It is not a T'ang production, but of exactly the same type as our early porcelanous ware. 
Emperor Wen. Mr. Gammon told me that he had bought the jar on the spot where it was found. The jar itself, like the others belonging to us, was welded or coiled up by hand before a summary smoothing-off on the wheel. It had four loop handles, finger-modelled, at the shoulder (two only of these remain), and was glazed in a thin running blackish-green, of which the little that still adheres is for the most part oxidized to dull brownish-ochre. The clay is softer than your shards, and softer, too, than that of 12865 or $\mathrm{r} 2875$; but it seems to be quite the same in all other respects. It has the same admixture of black and occasional white particles in the mass of gray, the same unevenly ferruginous surface, and the same occasional thickening of that surface. The jar is much less well potted than your pieces and ours. Perhaps it is more primitive; that is, it may be an early example of the method used so expertly in making your jars and ours. Perhaps, on the other hand, it is simply cruder; that is, the potter may have used a well-known and well-developed method carelessly in making an unimportant vessel. Who knows? I incline toward the latter possibility.

"I dated the jar 'Han' because of the evidence of the coins found in it. Now, emboldened by your ascription of the date to the porcelanous jars, I shall classify No. 12865 in the Han period or shortly after. As regards 12875 , because of its different glaze and an obscure device impressed on its shoulder, I am not yet sure."

At my request $\mathrm{Mr}$. Kershaw was good enough to send me for examination the pan-liang copper coins, twenty-one all together, found in Mr. Gammon's jar. They all proved to be authentic, as particularly determined by close comparison with numerous corresponding issues in the Chalfant coin collection, and to have been issued under the Han. ${ }^{1}$ The presence of this batch of coins in that vessel is, of course, no absolute proof warranting us in assigning the vessel to the early Han period, as these coins may still have been in circulation long after Han times. In rgor I found in actual circulation at Si-ngan fu Han copper coins with the legend wu chu. A collection of twenty-one Han pan-liang coins in a single jar would rather hint at a high appreciation of this money, and such is rather more probable in post-Han than in Han times. At any rate, the exclusive presence of a single Han issue, together with the absence of any later coin, would seem to favor a period approaching very closely the age of the Han.

1 Money with this legend, weighing exactly half an ounce (pan-liang), was first issued under the Ts'in (see Chavannes, Mémoires historiques de Se-ma Ts"ien, Vol. III, pp. 539, 542). 
Several similar pieces have been collected by Mr. Orvar Karlbeck, an official of the Tientsin-Pukow Railway, residing at Chu-chou, Ngan-hui Province. This gentleman, in the course of several years' residence in China, has formed a very interesting collection of ancient pottery, that consists of 144 pieces. I did not have occasion to see it, but, judging from photographs and descriptions which he has been good enough to send me, he seems to own several bits such as are here under consideration.

Mr. R. L. Hobson, the prominent expert in pottery of the British Museum, while visiting Chicago in January, I9r3, and doing me the honor of studying the collections under my care, called my attention to two early jars of similar glazes which were found at Black Rock Hill in Fu-chou, and are now preserved in the British Museum. They are sketched and described by H. F. HoLr. ${ }^{1}$ They are oval-shaped jars, with short necks and straight rims, a pair of loop handles (in one piece double handles) being stuck on to the shoulders. They are described as being made "of a grayish clay resembling almost stoneware, over which a coat of greenish-brown glaze has been coarsely laid; a curved line at the bottom sharply defines where the glazing ended." The further remark, however, that the glaze is quite decomposed and can easily be detached, would rather hint at this glaze being of a character different from that on our specimens, which, owing to its chemical composition, is not capable of decomposition. The great antiquity of these two jars is not doubtful: in shape and style they are true descendants of Han pottery. Holt adduces an interesting piece of evidence as to their age,- the fact that the grave in which they were found was situated within the city-walls; and, as no burial within the latter is permitted, they would seem to have been deposited there at a time prior to the erection of the wall. He refers to the "Geography of the Manchu Dynasty" (Ta Ts'ing $i$ t'ung chi) as containing the information that in A.D. $625 \mathrm{Fu}$-chou was a city of the first class.

$\mathrm{Mr}$. Hobson was also good enough to read in manuscript $\mathrm{Mr}$. Nichols's report, that follows, and to anticipate some of these results in his admirable work "Chinese Pottery and Porcelain," ${ }^{2}$ which denotes decided progress in our knowledge of the entire subject, and is now the best general handbook on porcelain. Referring to Mr. Nichols's analyses of the body and glaze of this pottery, Mr. Hobson states, "The results show that the body is composed of a kaolin-like material

1 On Chinese Cinerary Urns (Journal British Archaological Association, Vol. XXVII, i87 I, pp. 343-349, Plate XVII).

${ }^{2}$ Vol. I, p. I5 (New York and London, I915). 
(probably a kind of decomposed pegmatite), and is, in fact, an incipient porcelain, lacking a sufficient grinding of the material. The glaze is composed of the same material softened with powdered limestone and colored with iron oxide. . . . The nature of the pottery, in spite of its coarse grain and dark color, which is probably due in part to the presence of iron in the clay, seems to show that the manufacture of porcelain was not far distant."

The report of Mr. Nichols is of sufficient importance and interest to warrant its publication in full. It is divided into two parts. Part I is devoted to a detailed investigation of the ancient porcelanous ware; and, in order to render possible a comparison with the earlier Han pottery, analysis of a green glaze from a bowl of Han pottery follows in Part II. 


\title{
REPORT ON A TECHNICAL INVESTIGATION OF ANCIENT CHINESE POTTERY
}

\author{
By H. W. Nichols
}

\section{Porcelanous Han Pottery}

For the purpose of analysis, one fragment about two inches long and two inches wide, and a number of smaller pieces, were examined. The body of the ware, which is from three-sixteenths to one-quarter of an inch thick, consists of a gray vitrified porous substance which contains a few scattered black specks of minute size and glassy lustre. The body is coated on the outside with a very thin opaque red slip, and on the inside with a white engobe and a thick transparent greenish-yellow glaze.

Chemical Characters of the Body.-An analysis of the body from which both the inner and outer glaze and engobe coats had been removed, but with the black specks included, was made in the Museum laboratory.

ANalysis of Body

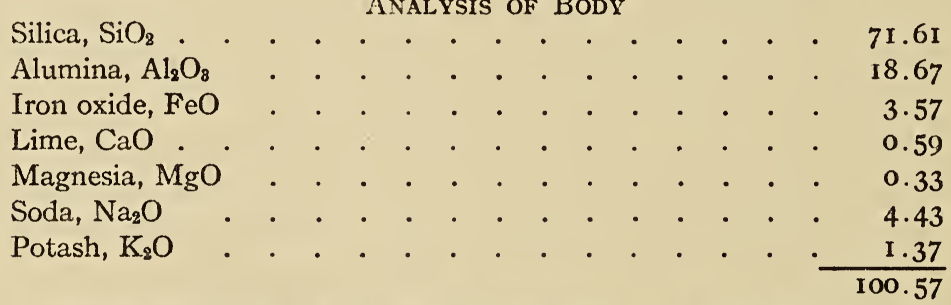

When this is compared with other analyses, it must be remembered that there are small ferruginous specks scattered through this body, so that the iron content shown by the analysis is higher than that of the true body substance.

Table Showing Analysis of Ancient Chinese Pottery

In comparison with that of modern Chinese and Japanese porcelains

\begin{tabular}{|c|c|c|c|c|c|c|c|c|c|}
\hline \multirow[b]{2}{*}{ Silica, $\mathrm{SiO}_{2}$. } & & & & & & & & & \\
\hline & & 71.61 & 74.53 & 71.31 & 69 & 70 & 73.30 & 69 & 70.50 \\
\hline Alumina, $\mathrm{Al}_{2} \mathrm{O}_{3}$ & & 18.67 & 16.09 & 19.74 & 23.60 & 22.20 & 19.30 & $21 \cdot 30$ & 20.70 \\
\hline Iron oxide, $\mathrm{FeO}$ & & $3 \cdot 57$ & 1.03 & 0.73 & 1.20 & 2 & 3.40 & 0.80 & 0.80 \\
\hline Lime, $\mathrm{CaO}$. & & 0.59 & 0.06 & 0.17 & 0.30 & 0.80 & 0.60 & I. 10 & 0.50 \\
\hline Magnesia, MgO & & 0.33 & 0.25 & 2.04 & 0.20 & trace & trace & trace & trace \\
\hline Soda, $\mathrm{Na}_{2} \mathrm{O}$ & & $4 \cdot 43$ & I. 19 & 0.10 & $3 \cdot 30$ & 3.60 & 2.50 & 3.40 & \\
\hline tash, $\mathrm{K}_{2} \mathrm{O}$ & & I. 37 & $4 \cdot 37$ & 4.04 & 2.90 & 2.70 & 2.30 & 1.80 & \\
\hline
\end{tabular}

A.-Ancient porcelanous Chinese pottery in question, analysis by H. W. Nichols. B.--Modern Japanese porcelains, analyses by H. A. SEgER (see his Collected Writings, Vol. II,

C.--Modern Chinese porcelains, analyses by A. SAlvETAT, contained in the work of S. JULIEN, Histoire et fabrication de la porcelaine chinoise, p. Lxxxvi (Paris, 1856). 
The analysis proves that this body has all the chemical characters of a true porcelain. Its resemblance to the analyses of Japanese porcelains made by SEGER ${ }^{1}$ is remarkable.

The silica and alumina both fall within the rather narrow limits set by Seger for this ware. The important deviations from the composition of Japanese porcelain are precisely those which characterize modern Chinese porcelains. These are: the high content of iron, in this instance of little significance; the high alkali content; and the excess of potash over soda. An important feature in the composition of porcelain and pottery bodies is the silica-alumina ratio. The ware presents, in this feature, a decidedly Japanese aspect. The Chinese porcelains analyzed by Salvétat generally are higher in alumina, and lower in silica, than this specimen and the Japanese bodies. The analyses of Chinese porcelain indicate a decidedly variable composition, as might be expected from Julien's description of the rather haphazard way in which the mixtures are made. In respect to this silica-alumina ratio, which sharply distinguishes Oriental from Occidental porcelains, the ancient bit of pottery under consideration comes distinctly into the Oriental class.

The quantity of alkali is essentially the same as in Salvétat's analyses of modern Chinese porcelains. Salvétat's average is $5.59 \%$, while this ware contains $5.80 \%$. The quantity of iron in some of Salvétat's specimens is essentially as great as that of this specimen. The variation among themselves of the analyses of modern Chinese porcelain is fully as great as the difference between these and the pottery under discussion. As the chemical composition of the ware is that of a good porcelain, the reason it failed to make a fine ware must be sought in those physical features which are consequent on the handling of the materials during manufacture, and not in any qualities inherent in the nature of the materials themselves.

Physical Characters of the Body. - The body is composed of a gray vitrified material, with the slightly greasy lustre characteristic of some varieties of vitrified ware. Under an ordinary hand magnifyingglass, it appears as a kind of solidified froth composed of pores enclosed by thin walls of a translucent porcelain-like substance. These pores are elongated, so that there is a well-defined laminated structure. There are numerous inclusions of a black and glassy iron slag. Each of these glassy inclusions surrounds a minute spherical bubble. Throughout the body there are angular patches of lighter and darker gray which are vestiges of coarse particles in the mixture from which the body

${ }^{1}$ Collected Writings, Vol. II, pp. 687 and 716. 
was burned. In thin fragments the material is somewhat translucent. A somewhat thick micro-section transmits light as freely as do many rock-sections, although confusion from the overlapping of much fine detail does not permit a very profitable study of the section.

It is not possible to tell from the examination of any well-burned vitrified ware whether the mixture from which it is burned is of natural or artificial origin. It would not be at all impossible, although perhaps a task of some difficulty, to find along the outcrop of some pegmatite dike kaolin-like material from which a body identical with this might be burned. The Japanese, formerly at any rate, burned their wares from a single clay, while the Chinese use a mixture. This ware might have been prepared either way.

The raw material contained iron-bearing minerals in coarse grains only. Each grain has left its individual splash of glassy black slag. The absence of any marked tone of buff, green, or yellow in the color of the mass indicates that there was no important quantity of finely-divided ferruginous mineral present. A simple and crude washing would have eliminated the iron-bearing minerals. Although the pottery does not look at all like porcelain, the only real point of difference, as far as the body is concerned, is the porosity of the ware. This porosity seems to be due to the use of too coarsely ground material, with not enough fine to fill the interspaces. It is a porcelain froth.

The Outside Red Graze.- The red glaze on the outside is very thin. Its surface is rough and interrupted by numerous minute black blotches, where ferruginous minerals from the body have penetrated. The glaze is very uniformly distributed. It has not run during firing, nor has it crazed since. It is in as good condition to-day, as on the day it was made. It has, as well as may be determined under a powerful magnifying-glass, the structure, or rather lack of structure, of a uniform, translucent, vitrified mass. It seems to be a simple slip of some good red-burning clay. It is so thin that a sample for analysis could not be obtained. Between the red coating and the body is a white engobe coat. This nowhere exceeds one-tenth of a millimetre in thickness. It differs from the similar coating under the transparent glaze of the inside of the vessel only in its greater thinness and in the possession of a slight pinkish color, apparently absorbed from the overlying glaze. In places this coat becomes very thin and even occasionally disappears.

The Inside Glaze. - That surface of the fragment examined, which corresponds to the inside of the vessel of which it formed a part, is covered with a transparent glaze upon a porcelain-like engobe. This engobe coat is thicker than that upon the outside of the vessel. 
Its average thickness is one-quarter millimetre, but this thickness is very variable. Although it is not pure white in color, it is of a distinctly lighter gray than the body; also it differs from the body, in that it is compact and free from pores. When examined under a hand magnifying-glass, it seems to be very sharply and distinctly separated from the body. When examined as a thin section under the microscope, the sharp line of demarcation disappears, as well as the difference in color. It then seems to be of the same material as the body freed from ferruginous particles and from coarse grains, so that it has vitrified into a dense non-porous body. The object of such a coating as this is twofold: it provides a light-colored background for the transparent glaze, whereby its brilliancy is enhanced; and it provides an impervious support for the glaze, which otherwise might be absorbed into the pores of the body during the firing. The appearance of the material, when viewed in the form of a micro-section, suggests that this coat is merely the result of floating the finer particles of the mix to the surface during the process of forming the vessel. This would ordinarily be accomplished by the friction of the hand or of some tool. But the coating under the more fusible glaze, where its presence is imperative, is much thicker than that under the less fusible glaze, where the necessity for it is much less. The way the coarse particles of the body project through the red glaze is difficult to understand on the theory of a floated surface; and there are no signs of dragging along the surface of those coarse particles which lie immediately under the surface; also it would be difficult to float so much fine material when the deficiency of this matter is such as to leave so many voids in the interior. The preponderance of evidence indicates that this material is an engobe coat put on possibly by dipping, but more probably by spraying. In both its physical and chemical aspect, this coat is a true porcelain.

The glaze is a greenish-yellow glass, brown in the thicker places. It is of variable thickness, as it ran badly during firing. Aside from this serious deficiency, it is a remarkably good glaze. It still adheres firmly to the body, and there has been no chipping or scaling. The crazing takes the form of a fine and uniform network of cracks. The brilliancy is very great, and there is no sign of devitrification. The attainment of these qualities, especially the continued perfect adhesion, which necessitates a very nice adjustment of the coefficients of expansion of body and glaze, indicates that the potters had already attained a high degree of skill. Running of a glaze of this type during firing is a condition unusually difficult to contend with. The color almost certainly identifies this glaze as a lime-alumina-iron silicate, and this is verified by an analysis made in the Museum laboratories. 


\section{Analysis of the Glaze}

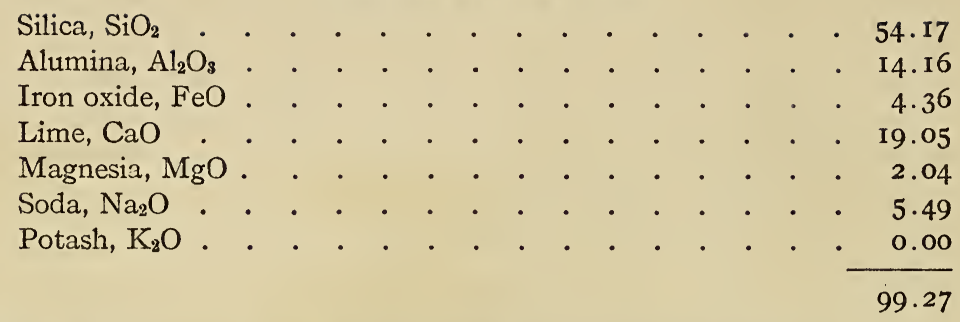

This is obviously an alkali-lime-iron-alumina silicate glaze. This is so purely a Chinese type, that it is useless to compare it with any but Chinese glazes. Even the Japanese glazes differ materially from those of the Chinese, being intermediate in character between these and the European. Those Chinese porcelain glazes the analyses of which have been examined are all white, and hence free or nearly so from iron. The influence of iron on a glaze is very great, and extends to nearly all its properties. Hence, in modifying a yellow glaze to a white one, there is much to do in the way of readjusting the proportions of all the elements, besides removing the iron. Therefore the close correspondence which appeared among the several body analyses will not be found to hold between the yellow and the colorless glazes, even if one has been derived from the other.

\section{Comparative Table of Chinese Glazes}

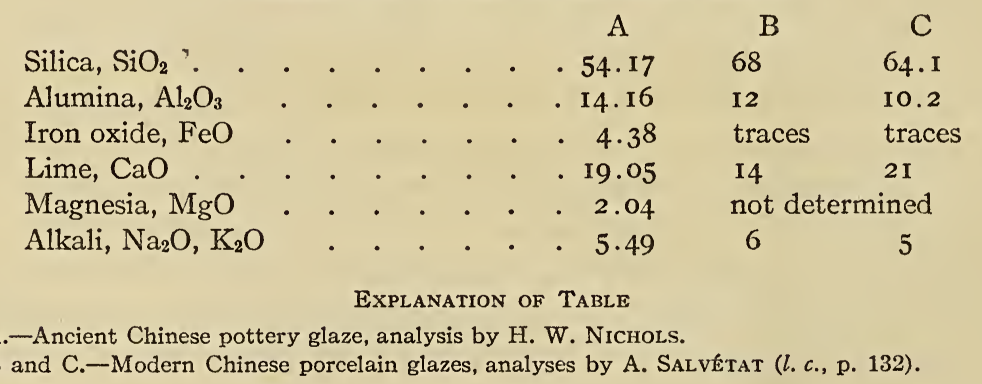

The glaze on porcelain is thin, and Salvétat evidently had difficulty in securing enough material for a thorough analysis. The examples given in the table are sufficient to show that all these glazes are of the same character.

A comparison of the compositions of glaze and body suggests that the glaze has been prepared by mixing the material of the body with pulverized limestone. A brief calculation of the quantitative relations between the several elements of body and glaze confirms this impression in such a manner that there can remain no doubt as to the mode of 
preparation of the glaze. It must have been made by the addition of approximately one part of limestone, or the lime burned from it, to two parts of the clay from which the body was prepared. It is also possible, but not certain, that small quantities of soda and oxide of iron were added to rectify minor defects.

The calculation follows: It is assumed that the limestone is a pure, more or less magnesian, limestone, such as would naturally be employed. The limestone is taken to be somewhat magnesian, partly from inspection of the analyses, and partly because a non-magnesian limestone is rather an unusual rock. As such a limestone is practically free from silica, the silica of the glaze must come from the clay, and the ratio of the silicas in body and glaze will give a measure of the quantity of clay used in the mixture. As the body contains 7 1.61\% silica, and the glaze $54.17 \%$, it is evident that, ignoring for the present losses in burning, 75.66 parts of clay were used per roo parts of glaze. The following table may then be readily calculated:

Table showing Relations between the Composition of the Glaze and of A Mixture of $75.66 \%$ of the Pottery Body with $24.34 \%$ of Lime

\begin{tabular}{|c|c|c|c|c|c|c|c|}
\hline & & BODY & $\begin{array}{l}75.66 \% \\
\text { OF BODY }\end{array}$ & GLAZE & $\begin{array}{l}\text { DIFFER- } \\
\text { ENCE }\end{array}$ & $\begin{array}{l}\text { LIME- } \\
\text { STONE }\end{array}$ & EXCESS \\
\hline Silica, $\mathrm{SiO}_{2}$ & & $7 \mathrm{I} .6 \mathrm{I}$ & 54.17 & 54.17 & 0.00 & $\ldots$ & 0.00 \\
\hline Alumina, $\mathrm{Al}_{2} \mathrm{O}_{3}$ & • & I 8.67 & 14.12 & I4. I6 & -0.04 & $\ldots$ & -0.04 \\
\hline Iron oxide, $\mathrm{FeO}$ & - & $3 \cdot 57$ & 2.70 & $4 \cdot 36$ & I. 66 & $\ldots$ & I. 66 \\
\hline Lime, $\mathrm{CaO}$ & . & 0.59 & 0.45 & 19.05 & I8.60 & 18.60 & 0.00 \\
\hline Magnesia, $\mathrm{MgO}$. & . & 0.33 & 0.25 & 2.04 & I.79 & I.79 & 0.00 \\
\hline Soda, $\mathrm{Na}_{2} \mathrm{O}$. & - & $4 \cdot 43$ & $3 \cdot 35$ & 5.49 & 2.14 & $\ldots$ & 2.14 \\
\hline Potash, $\mathrm{K}_{2} \mathrm{O}$ & & I. 37 & I. 04 & 0.00 & -I.04 & $\ldots$ & $-\mathbf{I} .04$ \\
\hline Carbonic Acid, $\mathrm{CO}_{2}$ & & $\ldots$ & $\ldots$ & $\ldots$ & $\ldots$ & 16.54 & $\ldots$ \\
\hline & & 100.57 & 76.08 & 99.27 & & 36.93 & \\
\hline
\end{tabular}

In the column marked "excess" are recorded the differences between the actual and computed compositions of the glaze. These differences are trifling. The absence of potash from the glaze is in line with the known volatilization of potash from the surface of wares subject to the kiln fires.

The slight excess of iron oxide and soda in the mixture is not surprising, as crude, untreated earths of the kind used are by no means uniform in composition, and greater discrepancies than this are to be expected in analyses of consecutive batches of such material. Especially common is such an interchange of potash and soda as appears in this instance. The correspondences between figures and theory are, in fact, so close, that it is probable that the material employed was carefully selected by such physical characters as color, texture, etc. 
It is of course possible that the potters had learned to adjust the qualities of the glaze by small additions of alkali and iron oxide. Slight variations in the quantity of either of these substances greatly influence the physical properties of the glaze.

This table cannot give more than a rough approximation of the quantities of the two ingredients of the mixture, as the losses of volatile matter in both limestone and clay during burning cannot be computed with accuracy. The table suggests that not far from one part of limestone to two parts of clay were employed. We may safely conclude that this glaze was made by adding pulverized limestone, lime, or milk of lime to the material from which the body of the pottery was made. The modern Chinese glaze for porcelain is made by mixing lime with one of the two ingredients of which they make the body. This process seems to be peculiar to China.

Conclusions. - At the time this ware was made, the potters had already acquired a high degree of dexterity. Many of the things that they accomplished in the fabrication of this pottery required technical skill of no mean order. The engobe coat, without which no satisfactory glaze could be made upon so porous a ware, was used. The expansion of the glaze has been very accurately adjusted to that of the body. The glaze is remarkably brilliant for one free from lead. The glaze has no large bubbles, nor are small bubbles numerous enough to cloud the ware. On the other hand, they made the glaze too thick, and they could not prevent it from running during the firing.

With potters as skilful as these, the discovery of methods of overcoming the porosity of the ware, and thus making it a true porcelain, should be only a matter of time. As the engobe coat is porcelain, it is quite possible that the knowledge was not lacking even at that time. They may not have realized that a dense ware would be worth the great expense involved in grinding the materials to the necessary fineness by the crude methods then available, and in the control of the drying and firing methods to prevent distortion of the ware.

\section{Analysis of a Green Glaze from a Bowl of Han Pottery}

This is a brilliant glassy glaze of a bottle-green color from a Han pottery bowl (Cat. No. II8578). It is thickly applied over a red porous body.

It is believed that the material selected for analysis correctly represents the original unaltered glaze. The glaze with its red backing was crushed to fragments of about a millimetre average size, and clear unaltered fragments were selected after scrutiny under a powerful 
glass. These fragments were freed from the adhering films of red earthy matter by use of forceps and a fine file. As finally prepared, the glass showed no altered material, nor any but a few unweighable traces of earthy matter.

The analysis gives:

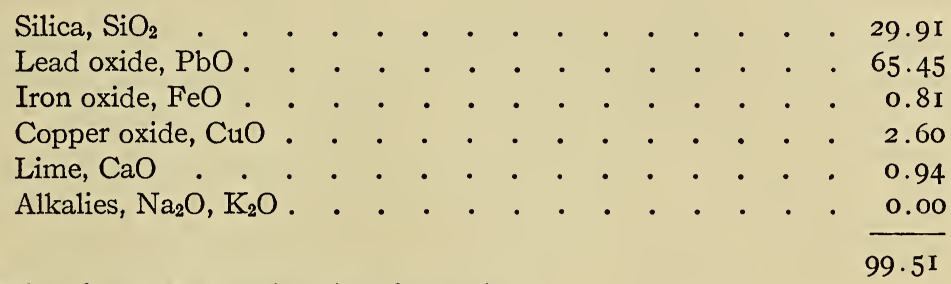

This gives the molecular formula:

$$
\text { I RO : I. } 4 \mathrm{SiO}_{2} \text { or nearly } 5 \text { RO. } 7 \mathrm{SiO}_{2} \text {. }
$$

The traces of iron and lime are obviously impurities.

This is a simple lead silicate colored by copper, and is utterly unlike any glaze of which I have any analysis, the nearest approach to it being the alkali-lead silicate which seems to have been an ordinary glaze in all countries. The omission of alkali places this glaze in a very different class. It could be easily and simply compounded, as there are but three ingredients,- - some lead salt (perhaps red lead or white lead), a pure white sand, and a small quantity of some copper compound for coloring.

Professor R. T. Stull, Acting Director of the Ceramic Department of the University of Illinois, has been good enough to supply the following additional information on the preceding analysis:

"I am very much interested in the data you present on the early Chinese glaze. I have calculated an approximate empirical formula from the analysis, which gives:

$$
\begin{array}{ll}
.827 \mathrm{PbO} & \\
.093 \mathrm{CuO} & \text { I.408 } \mathrm{SiO}_{2} \\
.049 \mathrm{CaO} & \\
.03 \mathrm{I} \mathrm{FeO} &
\end{array}
$$

"This approximates closely the theoretical formula:

$$
\left.\begin{array}{l}
.9 \mathrm{PbO} \\
. \mathrm{I} \mathrm{CuO}
\end{array}\right\} \text { I. } 5 \mathrm{SiO}_{2}=2 \mathrm{RO} .3 \mathrm{SiO}_{2}
$$

A glaze can be made by mixing the following materials, which would be very similar to the Chinese glaze when first made:

$\begin{array}{lr}\text { Red lead } & 205 \\ \text { Copper oxide } & 8 \\ \text { Potter's flint } & 90\end{array}$


It is quite probable that the Chinese glaze was originally made by mixing together three ingredients, - a lead compound, a copper compound, and a form of silica. The iron and lime present were probably impurities existing in the raw materials used in making the glaze. A glaze of this type (which is in reality a glass, since glazes generally contain alumina) fuses at a very low temperature, is very brilliant, has a high specific gravity, high index of refraction, and high coefficient of expansion; and is easily dissolved by chemical agents (comparatively so). Owing to the high coefficient of expansion, the glaze is very susceptible to crazing. The glaze could be improved by the addition of alumina in the form of clay, which would lower the coefficient of expansion, thus reducing crazing, and would make the glaze more resistant to the weathering action or to chemical agents. In good glaze practice, it is customary to introduce an alkali in some form, although good glazes can be produced without the use of alkali. One glaze being used for glazing roofing tile has the formula:

$$
\begin{aligned}
& \text {.9 } \mathrm{PbO} \\
& \text {. I } \mathrm{CuO} \\
& \text {.I } 5 \mathrm{Al}_{2} \mathrm{O}_{3} \text { I. } 6 \mathrm{SiO}_{2} \text {, }
\end{aligned}
$$

which is very similar to the Chinese glaze plus $\mathrm{Al}_{2} \mathrm{O}_{3}$. A mixture which will produce this glaze is:

$\begin{array}{lr}\text { Red lead } & 205 \\ \text { Copper oxide } & 8 \\ \text { Ball clay } & 39 \\ \text { Potter's flint } & 78\end{array}$

If the Chinese glaze has been disintegrated by long exposure, the alkalis would naturally be leached out partially, if not entirely."

1 The material for analysis was carefully-picked, unaltered fragments [H.w.N.]. 


\section{HISTORICAL OBSERVATIONS AND CONCLUSIONS}

The preceding report of Mr. Nichols leaves no doubt that the pottery in question, as confirmed by Mr. Hobson, is a porcelanous or porcelain-like ware, as regards the composition of both body and glaze. It is a forerunner of true porcelain; it represents one of the initial or primitive stages of development through which porcelain must have passed before it could reach that state of perfection for which the Chinese product gained fame throughout the world. The history of porcelain has been singularly exposed to misrepresentations and misunderstandings, chiefly for the reason that Chinese accounts of the subject are obscure, enigmatic, and, moreover, disappointingly meagre and unsatisfactory. In his eminently critical and excellent work, Hobson has done a great deal to eradicate many of the old superstitions. It was obvious that the problem of the origin of porcelain could be solved only by archæological, not by philological, methods; and it is due to the investigations of Mr. Nichols that we may now for the first time formulate certain opinions regarding the beginnings of porcelain, which are grounded on matter-of-fact observation, and not on a more or less arbitrary interpretation of texts. Therefore the question may first be discussed from an archæological viewpoint; and then it remains to be seen whether, with the result thus obtained, Chinese traditions may not be better and more profitably understood.

Before attempting to determine the date of the "Han" porcelanous ware, it will be useful to raise the question whether there is now a possibility of dating the first manufacture of true porcelain. I shall not insist on the evidence deduced by Bushell and Hobson from Chinese sources, to the effect that porcelain was made under the T'ang dynasty (6I8-906) as early as the beginning of the seventh century. Reference will be made to only one source which has not yet been enlisted for the study of the question, and then we may proceed to archæological evidence.

An incontrovertible proof for the existence of porcelain in the seventh century is contained in the memorable account of the Buddhist pilgrim I-tsing (635-7I3), who visited India from 67 I to 695 . In discussing the utensils to be utilized by the monks of India, I-tsing speaks also of Indian earthenware vessels, and remarks, "In India, there was originally neither porcelain ( $t s^{\prime} e$ 瓷) nor lacquer. Porcelain, if glazed, is no doubt clean. Lacquered articles are sometimes brought to India 
by traders." It is evident beyond cavil that I-tsing understands the word $t s^{\prime} e$ in this passage in the sense of porcelain with which he was familiar in his native country. He could most assuredly not mean to say that pottery was originally unknown in India, for in more than one case he himself refers to Indian pottery or earthenware (wa which could not escape the attention of a keen observer like him. He expressly avails himself of the word $t s^{\prime} e$ in this passage, advisedly in contradistinction to the word wa used previously, and connects it with another characteristic product through which China then became widely known,- - lacquer. He does not state explicitly that porcelain, in the same manner as lacquer-ware, was then imported from China into India; but this fact may be inferred from the statement made in the beginning of Chapter VI, that "earthenware and porcelain (wa $t s^{\prime} e$ 瓦淘) are used for the clean jar" (that is, the jar containing the water for drinking-purposes). ${ }^{2}$ This passage is sufficient evidence for the fact that porcelain was then found in India; and also his statement that porcelain did not originally exist in India seems to impiy that it occurred there at the time of the author's visit. He does not speak of porcelain as a new, but as a familiar, production; and he must certainly have seen it in China before the year $67 \mathrm{x}$, the date of his departure for India. Judging from I-tsing's memoirs, porcelain, accordingly, must have existed in China during the latter half of the seventh century. At the same time, it was exported into India; and this harmonizes with the observation made in the $T^{\prime}$ ao shuo, that porcelain bowls were widely distributed abroad from the time of the T'ang dynasty (6r8-906). ${ }^{3}$

The testimony of the Arabic merchant Soleyman, who in $85 \mathrm{I}$ wrote his "Chain of Chronicles," must be regarded as one of the most weighty to prove the existence in China of true porcelain in the age of the T'ang, during the ninth century. In the translation of

$1 \mathrm{~J}$. TAKakusu, A Record of the Buddhist Religion as practised in India by I-tsing, p. 36 (Oxford, I896); Japanese edition of the text, Vol. I, p. I7 a.

${ }^{2}$ L.c., p. 27 ; text, Vol. I, p. I2 a.

${ }^{3} T^{*} a o$ shuo, Ch. 5, p. 2 b (edition with movable types, published I9I3); S. W. Bushell, Description of Chinese Pottery and Porcelain, p. I04.-According to W. Crooke (Natives of Northern India, p. I36, London, I907), common clay pots, owing to their perishable character, are little valued in India, "and caste prejudices prevent the use of the finer kinds of pottery. Hence no artistic industry like that of china has flourished in India, although kaolin and other suitable kinds of clay are in some places abundant." We have a formal judgment on Indian pottery from the Buddhist monk Yüan Ying, who in his Yi ts'ie king yin $i$ (Ch. 18, p. 7; see p. I I5), written about A.D. 649, remarks that the state of culture is so low in the Western Regions that finer pottery cannot be made there, and that only unburnt bricks and vessels fired without glaze are turned out. 
M. REINAUd, " he reports that "there is in China a very fine clay from which are made vases having the transparency of glass bottles; water in these vases is visible through them, and yet they are made of clay." 2

The presence of china in the India of the seventh century, and the acquaintance of the Arabs with transparent porcelain in the ninth century, based on literary sources, naturally raise the question whether this documentary evidence is corroborated by any archæological facts. Such have heretofore been lacking; but an important discovery due to the excavations of F. Sarre and E. Herzfeld in the ruins of Samarra, the former residence of the Caliphs, is fortunately apt to settle satisfactorily this much-disputed question. The report of these remarkable finds has recently been published. ${ }^{3}$ According to F. Sarre, who carefully figures and describes these objects, they belong to a period which is well determined by the years A.D. 838 and 883 . The ceramic specimens exhumed in Samarra fall into two classes,- those imported from eastern Asia, and those potted locally for home-consumption. Among the former we are confronted with a material which in general must be designated as stoneware, but which, to use the words of Sarre, partially approaches porcelain to such a high degree that it may straightway be styled "porcelain." In the latter case, the body of the vessels cannot be scratched by steel, is almost white, transparent in thin places, the shards being dense, and hard like shell. The smooth and brilliant glaze is evenly applied, and so closely linked with the body that both can but have been fired simultaneously,- characteristic qualities of genuine East-Asiatic porcelain. Besides fragments of more or less coarse and shallow bowls, whose low rim around the bottom is ground off, those of finer ware have also come to light; thus, for instance, a fragmentary oval cup decorated with a fish in relief, surrounded by wave designs and birds on the wing. Judging from the author's description and the very excellent illustrations, there is no room for

${ }^{1}$ Relation des voyages faits par les Arabes et les Persans dans 1'Inde et à la Chine, Vol. I, p. 34 .

${ }^{2}$ The report of Soleyman is in full accord with the Chinese notices of T'ang pottery. In the beginning of the T'ang dynasty (6I8), vases of a white clay, with thin body of white and brilliant color, were made by a potter of the name $\mathrm{T}^{\mathrm{a}} \mathrm{ao}$, in the village Chung-siu, belonging to King-te-chen; they were styled "imitation jade utensils," and sent as tribute to the Court. Similar vessels were turned out simultaneously by Ho Chung-ch'u from the village Tung-shan (King te chen t'ao $l u$, Ch. 5, p. I b; Julien, Histoire, pp. 8I, 82). It is notable that both potters were rural residents, and that their work possessed sufficient quality to earn imperial approbation.

${ }^{3}$ F. SARRE, Die Kleinfunde von Samarra und ihre Ergebnisse für das islamische Kunstgewerbe des 9. Jahrhunderts (Der Islam, Vol. V, I9I4, pp. I80-195, 4 plates). 
doubt that the piece in question is of real, white porcelain, and that it affords an example of the hitherto lost porcelain of the T'ang period. T'ang porcelain is thus raised into the rank of plain fact. Soleyman's testimony proves true.

The date of this specimen is indubitable, and meets a welcome confirmation from two green and white glazed dishes of pottery ${ }^{1}$ secured in the same locality. Without having any clew to their provenience, the writer, who through his researches in China is somewhat familiar with this and similar ware, would not hesitate for a moment to diagnose them as Chinese productions of the epoch of the T'ang. Mr. Sarre is perfectly correct in calling attention to the fact that pieces of identical technique are preserved in the Imperial Treasury of Nara in Japan, and that T'ang clay statuettes are formed of the same material. Another discovery of no less importance, for which we are indebted to Mr. Sarre's energy, is a group of celadon-like stoneware, one of which, bearing the design of a fish scratched in under the glaze, is reproduced in his report. The facts brought out by Mr. Sarre's researches are of such far-reaching consequence, that he is entitled to a just claim to our lasting gratitude. Above all, he has succeeded in safely establishing the fundamental fact that porcelain was made in China under the T'ang; and that Chinese porcelain, as well as non-porcelanous pottery, was exported in the ninth century into the Empire of the Caliphs. These conclusions embolden us and justify us in regarding the word $t s^{\prime} e$, whenever it appears in T'ang documents, as conveying the notion of true porcelain, and in giving full credence to the account of I-tsing, that India possessed Chinese porcelain during the seventh century. ${ }^{2}$ Consequently it is at some earlier date that the beginnings of porcelain - those initiatory and preparatory steps finally leading up to the perfection of the ware- must be sought for. Porcelain has been discovered in Turkistan by Sir Aurel Stein. ${ }^{3}$

Our previous knowledge of references to T'ang porcelain was chiefly based on the two modern works, the King te chen t'ao lu (first edition, I 8I 5) and the $T^{\prime}$ ao shuo (I 774). It remains to be ascertained, however, from the contemporaneous records of the T'ang, whether these extracts

${ }^{1}$ On Plate II in the article referred to.

${ }^{2}$ As shown by I-tsing, a clear distinction between common pottery and porcelain is made in T'ang literature. This is further evidenced by the frequent occurrence of the compound $t s^{\circ} e w a$ 瓷互 ("porcelain and stoneware"), for instance, in the Yu yang tsa tsu (Ch. II, p. 7 b; ed. of Pai hai) and in the Ta T"ang sin yï 大唐 新語 (Ch. I3, p. 9; ed. of T'ang Sung ts'ung shu).

${ }^{3}$ Ancient Khotan, Vol. I, pp. 46I, 464 (see also Hobson, Chinese Pottery and Porcelain, Vol. I, p. I49). It would be desirable that analyses be made and published of Sarre's and Stein's porcelains. 
are reliable and correctly reproduced. In the geographical chapters of the T'ang Annals we find under each locality an enumeration of the taxes in kind annually sent to the Court, and the T'ai p'ing huan yï ki of Yo Shi gives a still more extensive list of the products of the empire during that period. The following localities are known as having produced porcelain under the T'ang:-

I. Hing chou 邢州 (modern Shun-te fu in Chi-li) turned out white porcelain vessels 白笠器 ( $T^{*}$ ang shu, Ch. 39, p. 6; and T'ai p'ing huan yï ki, Ch. 59, p. 5), which were accepted as taxes.

2. Ting chou 定州 in Chi-li (T'ai p’ing huan yü ki, Ch. 62, p. 4 b); the T'ang Annals do not mention porcelain among its products.

3. ' Yu chou 幽州 (modern Yung-p'ing fu in Chi-li), according to T'ai p'ing huan yü ki, Ch. 69, p. 6.

4. Jao chou 铣州 in Kiang-si ( $T^{\prime} a i$ p'ing huan yü ki, Ch. Io7, p. 3).

5. Yüe chou 越州 (modern Shao-hing fu in Che-kiang), according to $T^{\prime}$ 'ang shu (Ch. 4I, p. 4 b) and T'ai p'ing huan yiu ki (Ch. 96, p. 5).

6. Ho-nan fu (according to T'ang leutien, Ch. 3, p. 4 b, ed. of Kuang ya shu kü, I895; and T'ai p'ing huan yü ki, Ch. 3, p. 8b).

As may readily be seen from Julien's translation (pp. 28 and 6), only two of these localities (Nos. I and 5) are mentioned in the King te chen $t^{\prime}$ ao $l u$ as having produced porcelain under the T'ang (not, however, Nos. 2-4); while several others are so designated, which cannot be verified from coeval documents. ${ }^{1}$

As established by archæological evidence, porcelain was an accomplished fact under the T'ang (6r8-906); and there is further good reason to assume that it existed in the latter part of the sixth century. ${ }^{2}$ It is futile, of course, to look for an inventor of porcelain, as has been done by E. Zimmermann. ${ }^{3}$ This invention of an inventor of porcelain is a romance, not history. Chinese records know absolutely nothing about such an inventor, simply for the reason that he never existed. Porcelain is not an "invention," that can be attributed to the efforts of an

${ }^{1}$ In the writer's forthcoming second part of Chinese Clay Figures will be found a chapter on T'ang pottery.

${ }^{2}$ Bushell, Description of Chinese Pottery, p. xIr; Hobson, Chinese Pottery and Porcelain, Vol. I, p. I47. In 1844 , during the negotiations preceding the Franco-Chinese Treaty, one of the Chinese envoys, Chao Chang-li, well acquainted with the antiquities of his country, assured N. Rondot that the manufacture of porcelain could be traced back only as far as the middle of the sixth century (see Journal China Branch Roy. As. Soc., Vol. XXXII, r897-98, p. 73).

3 Orientalisches Archiv, Vol. II, I9I I, pp. 30-34; and Chinesisches Porzellan, p. 24. I strictly concur with HoBson (l. c., Vol. I, p. I45) in his criticism of Zimmermann's hypothesis. 
individual; but it was a slow and gradual process of finding, groping, and experimenting, the outcome of the united exertions of several centuries and generations. We clearly observe a rising development of porcelain from the T'ang to the Sung, Yüan, and Ming periods, till the high perfection of the ware culminates in the K'ang-hi era. It is therefore logical to assume that preceding the age of the Sui (590-6r 7 ) there was a primitive stage of development which ultimately resulted in the T'ang porcelain. This primeval porcelanous product was hitherto unknown, but, as demonstrated by the researches of Mr. Nichols, its existence is now proved in the nine vessels figured on Plates I and III-X, with analogous specimens in the Boston Fine Arts Museum, the Freer collection, and the British Museum. The tentative attributions "T"ang" and "Sung" (p. 82) were based only on isolated cases, and ventured as personal impressions; they were not grounded on the fact of analytic study. The Han tradition of ceramic forms had completely died out under the T'ang and Sung, to give way to more graceful and pleasing shapes partially conceived under Iranian and Indian influences. As has been shown, the objects in question decidedly breathe the spirit of Han art in forms and decorative motives. There is good circumstantial evidence in the case of the jug on Plate I, discovered in the same grave with a Han cast-iron stove, and in that of the pan-liang coins of the Boston jar. Nevertheless I am not convinced that we are entitled to assign these vessels to the Later Han dynasty within its strict chronological boundaries (A.D. $25^{-220}$ ), as the predominant bulk of the kilnproducts turned out under the Han was common glazed and unglazed pottery (wa 瓦). ${ }^{1}$ Moreover, the new term $t s^{\prime} e$ 蒗, applied to porcelanous ware, does not yet occur in the contemporaneous records of the Han, at least such an occurrence has not yet been proved (see p. Io2); and this is the main reason which prompts me to the opinion that the pottery in question was manufactured in post-Han times, say, roughly, under the earlier Wei $(220-264)$, or toward the middle or in the latter part of the third century A.D. ${ }^{2}$ From a purely philological point of view,

1 This is the term employed for the burial pottery of the period in the Han Annals (Hou Han shu, Ch. I6, p. 3). It is therefore out of the question that the new term $t s^{2} e$, as stated by Hobson (l. c., Vol. I, p. I4I, note), should refer to the glazed pottery of the Han. Credit must be given also to the Chinese for their correct feeling for their own language and their own antiquities: the present-day Chinese style the glazed Han pottery liu-li wa (accordingly, with the same term as employed in the Han Annals), while the term $\operatorname{Han}_{t s^{\circ} e}$ is applied to the porcelanous ware here described. In this case, Chinese feeling signifies a hundred times more than all the hair-splitting and pedantic subtleties of European sinologues.

${ }^{2}$ It is curious that this result agrees with the opinion of Palladius (ChineseRussian Dictionary, Vol. II, p. 343), who held that the output of porcelain took its beginning from the Tsin dynasty $(263-420)$. 


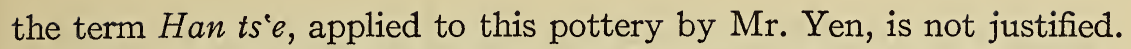
From the standpoint of the archæologist, however, it is perfectly correct; for this pottery, as recognized by Mr. Yen with just instinct or intuition, combines in itself two characteristic features,- the style of Han art, and the technical character of porcelanous ware. It is justifiable to regard it as a very early production, or even as one of the earliest, of the ware styled $t s^{\circ} e$. We might therefore say that porcelain ran through its experimental stages for at least three centuries; and it seems to me a reasonable conclusion that a development of such a length of time was required until mature and highly finished products should ultimately result.

It is possible also to make a plausible guess at the kiln, where the nine vessels were produced. As has been pointed out, the jug in Plate I was found in a grave near the village Ma-kia-chai, 5 li north of the town of Hien-yang 咸陽, the ancient capital of the Ts'in, belonging to the prcfecture of Si-ngan. The "Records of the Potteries of King-te-chen" inform us that "under the earlier Wei dynasty (220-264) vases were turned out at Kuan-chung 關 中, corresponding to Hien-yang and other places of the prefecture of Si-ngan, and that the output of this kiln was intended for the use of the Court, and offered to the Emperor." 1 Thus it is not impossible that our ware was actually made in the district of Hien-yang, or, taking the wider area, in the prefecture of Si-ngan. If the passage quoted should really be derived from an ancient text, which I am not in a position to prove, it would have another significance, in that it would represent the earliest allusion to pottery deemed worthy of being sent to the palace. Neither in times of antiquity nor under the Han do we hear of any tribute pottery. In the famous Tribute

${ }^{1}$ King te chen t'ao lu (edition of $\mathrm{r} 89 \mathrm{I}$ ), Ch. 7, p. I b. Julien (Histoire et fabrication de la porcelaine chinoise, p. 4), in his translation of these passages, speaks in both cases of "porcelain;" but this is not warranted by the Chinese text, which avails itself of the general term $t^{\prime} a o$ ("pottery"); but $t s^{*} e$ belonged to the class of $t^{\prime} a o$. Hobson (Chinese Pottery and Porcelain, Vol. I, p. I43) complains of Julien and Bushell having been indiscriminate in the use of the term "porcelain" in their translations from the Chinese. But how about LEGGE, who speaks of porcelain in the era of the Shi king? In his translation of this work, we read in two passages (pp. 346 and 502) of a "porcelain whistle," which is entered even in the index. Fortunately this musical instrument of porcelain has escaped the students and collectors of Chinese ceramics; otherwise we should probably meet it in one or another collection, since the collector usually gets what he wants or solicits. What is meant in the passage of the Shi king is the instrument hüan 墵, a pipe made of baked clay, of the size of a fowl's egg, and perforated by six apertures. Again, we read of "porcelain drums" in a translation of DE GROoT (Religious System of China, Vol. VI, p. 977) from a text of the Tu tuan by 'Ts'ai Yung (133-192), relative to conditions of the Chou period. The text has $t^{\prime} u k u$ 土鼓, which means "earthen drums." 
of Yü (Y $\ddot{u} k u n g$ ), forming a section of the Shu king, pottery is conspicuously absent. In pre-Han and Han times it had not yet reached such a state of perfection that it would have been brought to the immediate attention of the sovereign, or was eligible to take a place in the imperial chambers. It is conceivable that pottery of the class of our porcelanous ware was entitled to admission to Court, and answers to the tribute ware produced at Kuan-chung.

The origin of this mysterious and much-discussed term $t s^{*} e$ has been referred to the Han period by several European authors, but nobody has yet furnished any actual proof that the word really occurs in contemporaneous records of that age. Even Bushell ${ }^{1}$ merely states, "We know that the word $t s^{2} e$, which means porcelain in the present day, first came into use during the Han dynasty, and Mr. Hippisley takes this coining of a new word to designate the productions of that age to be a strong argument in favor of the early date. Others, more sceptical, before reaching any decision, ask to be shown actual specimens of translucent body that can be certainly referred to the period." Seven years later, Bushell became more confident and positive in his assertion of the origin of porcelain under the Han. In his work "Chinese Art," 2 an assurance to this effect is given in three passages. The word and character $t s^{2} e$, according to him, is first found in books of the Han dynasty. Again he asserts that the Chinese attribute the invention to the Han dynasty, when a new character $t s^{\prime} e$ was coined to designate, presumably, a new substance; ${ }^{3}$ and that "still we may reasonably accept the conclusion of the best native scholarship that porcelain was first made in the Han dynasty, without trying, as Stanislas Julien has tried on very insufficient grounds, to fix the precise date of its invention."

The only piece of evidence that has ever been produced to prove the existence of the term $t s^{2} e$ under the Han is the citation of this word in the glossary Shuo wen. Sceptics will naturally raise the question

${ }^{1}$ Oriental Ceramic Art, p. 20 (New York, 1899).

${ }^{2}$ Vol. II, pp. 4, I7, 20.

${ }^{3}$ The fact cited by Bushell on this occasion - that "the official memoir on 'Porcelain Administration' in the topography of Fou-liang says that, according to local tradition, the ceramic works at Sin-p'ing (an old name of Fou-liang) were founded in the time of the Han dynasty, and had been in constant operation ever since"- is not conclusive for a plea on behalf of porcelain at the time of the Han. That tradition, if correct, merely goes to show that kilns for the manufacture of pottery were established in that locality under the Han, while it implies nothing definite as to the specific character of this pottery. The fact that Fou-liang turned out porcelain at a later period does not allow of the inference that what was produced there in the era of the Han likewise was porcelain. 
whether the passage was actually contained in the original edition of the work (A.D. IOO), or whether it has been interpolated in the numerous subsequent re-editions. ${ }^{1}$ The decision of this question may be left to a competent sinologue. It means little for my purposes, as long as no instances of the word are pointed out in authentic books, which may be regarded as contemporaneous documents of the Han period. This much may be said, that the definition given in the Shuo wen has not been adequately explained. It has been asserted the definition should mean that $t s^{\prime} e$ is "pottery and nothing more." 2 It means, however, "Ts'e belongs to the category of pottery," or "is a kind of pottery." In the definitions of the Shuo wen, the word to be explained is defined by a more general word denoting the wider category. It cannot therefore be deduced from that gloss that $t s^{\prime} e$ in ancient times did not refer to porcelain, for porcelain certainly is a variety of pottery. In regard to the specific character of $t s^{\circ} e$, the definition of the Shuo wen is utterly inconclusive. Holding in abeyance the question as to the time when the term $t s^{\circ} e$ sprang into existence, and leaving aside all subtleties, it remains for plain common sense to say that a new term refers to a new matter, and that $t s^{\prime} e$ as a new ceramic term must have denoted a novel production achieved in the ceramic field. Such was the porcelanous ware as here described; and if, from the Sui and T'ang periods onward, the word $t s^{\prime} e$ was applied to true porcelain, it is self-evident that prior to that time it was attached to porcelanous ware, the forerunner of porcelain. The word $t s^{\prime} e$ did not plainly describe any pottery, but porcelanous pottery specifically.

It is known that the character $t s^{\prime} e$ 磁 is now employed also in place of $t s^{\circ} e$ 瓷. From this change of characters F. HrRTH ${ }^{3}$ believed he was justified in concluding that the new form, linked with the classifier 'stone' 石, indicates a substitute of material; while in the older form, combined with the classifier 'clay' be accentuated. This argumentation is unwarranted, and, as will be seen, does not answer the facts. Likewise the information given on this point in the "Catalogue of Potteries published by the Japan Society" (p. 56, New York, I9I4) is misleading. Here it is asserted that from the fact that the city Ts'e-chou produced porcelain, and that the word $t s^{\prime} e$ in the name of the city is phonetically identical with that of the word meaning "stoneware" or "porcelain," a certain confusion in

${ }^{1}$ Neither the Erh ya nor the Kuang ya contains the word; but also this proves nothing, as none of the ancient dictionaries is complete, and they surely lack numerous words which are found in literature.

${ }^{2}$ F. Hirth, Ancient Chinese Porcelain, p. I30.

${ }^{3}$ Ancient Chinese Porcelain, p. I30, note 3. 
the use of the word has arisen; "but there is no such confusion in the mind of the Chinese scholar; the purist never uses it; and all arguments as to the date of the origin of porcelain which have been based on the use of this word are valueless." All these statements are erroneous. No one has ever based any arguments on the use of this word as to the date of porcelain. In fact, the word has no concern whatever with the origin of porcelain. The chief facts in the case could already be gleaned from Julien's "Histoire" (p. 29). There is, first of all, a city by the name Ts'e-chou 磁州, which anciently depended on the prefecture of Chang-te in the province of Ho-nan, but which is now assigned to the prefecture of Kuang-p'ing in the province of Chi-li. The city had formerly various other names. The present name Tse ${ }^{\circ}$ 磁 was conferred on it in the year 590, at the time of the Sui dynasty. Near the boundary of the district rose the Loadstone Mountain (Ts'e shan 磁山) producing loadstone ( $t s^{\prime} e$ shi 磁石), whence the district and town received their name. ${ }^{1}$ At the time of the T'ang dynasty (6r8-906), the district produced nothing but loadstone and magnets made from it; it did not produce pottery of any kind. ${ }^{2}$ Only from under the Sung (960-r 278) did the locality in question embark on the manufacture of a kind of white porcelain, the choice specimens of which resembled the Ting ware. This particular kind of porcelain, because it originated from the locality of Ts'e, was styled "vessels of $T s^{\circ} e$ " ( $T s^{*} e k^{i} i$ 磁器). The word $t s^{\prime} e$ in this case, accordingly, denotes nothing but the place of provenience. "At present," the author of the "Records of the Potteries of King-te-chen" adds, "owing to a very common error, porcelain vases are generally designated by the term $t s^{*} e k^{i} i$ 磁器; people employing this term are doubtless ignorant of the fact that it applies in particular only to the porcelain of the city of Ts'e." The fact remains that under the Manchu dynasty, and at present, porcelain is invariably termed 瓷 and 磁, the latter character being more frequently employed. ${ }^{3}$ True it is, that K'ang-hi's Dictionary does not

${ }^{1} T^{\prime} a i$ p'ing huan yü ki, Ch. 56, p. ro b. The Pen ts'ao kang mu extols the loadstone of this locality as excellent (F. DE MÉLy, Lapidaires chinois, p. IO6), and loadstone was supplied from there as tribute to the Court (Ta Ts'ing $i$ l'ung chi, Ch. 31, p. I2).

${ }^{2}$ The silence of the $T^{\prime} a i p^{\prime} i n g$ huan yü ki and the T'ang Annals in this respect is conclusive, as the localities producing porcelanous ware at that time are expressly named (see above, p. 99). Hobson (Chinese Pottery and Porcelain, Vol. I, p. Ior) also arrives at the result that there is no information on the subject of Ts'e-chou factories earlier than the Sung dynasty, when they enjoyed a high reputation.

${ }^{3}$ Even in the T'ang Annals the term $t s^{\prime} e k^{\prime} i$ 磁器 appears, although we are not in a position to state that it was thus written in the original edition: the district Kü-lu 鉅鹿 in Hing-chou (now prefecture of Shun-te in Chi-li Province) sent porcelain vessels as tribute in the year $742\left(T^{*}\right.$ ang shu, Ch. 39, p. 6); and the fact that 
credit it with the meaning of "porcelain," but attributes to it only the proper significance, "loadstone." This, however, means nothing. Chinese standard works, like the great cyclopædia $T^{\prime} u$ shu tsi chieng and others, also the Japanese, employ this character throughout in the sense of "porcelain," so that there is no longer the question of confusion. On the contrary, it is a perfectly legitimate usage, even sanctioned by the English and Chinese Standard Dictionary issued by the Shanghai Commercial Press; and for this reason our own dictionaries, like those of Palladius, Giles, and Couvreur, are justified in assigning the meaning "porcelain" also to the character $t s^{\prime} e$ 磁. This was the outcome of a natural development of the language, which no alleged purism can sweep. The original term "porcelain of Ts' $\mathrm{e}$ " was simply amplified into the wider notion of porcelain in general, because the word $t s^{\prime} e$ employed in the name of the city bearing that name, and the word $t s^{\prime} e$ for "porcelain," though physically different words, phonetically are homophonous." This history of the subject clearly shows that Hirth's theory is untenable and should be discarded. The new word $t s^{\prime} e$ 磁, in the sense of "porcelain," has no organic and historical connection whatever with the older word for "porcelain" $t s^{\prime} e$ 瓷, but is an independent side-issue of purely incidental character. The alleged evolution from earthenware to stony material cannot be read from the formation of these characters, as they have nothing in common, and move along separate lines. This conclusion settles also the general speculation ${ }^{2}$ to the effect that the word $t s^{\prime} e$ in its origin should have meant nothing but common earthenware, and that gradual improvement of the ware resulted in changes of meaning and writing. We now recognize that the genuine character for $t s^{\prime} e \cdot \mathrm{c}_{\mathrm{c}}^{\mathrm{c}}$ has not been subject to any alterations, and that it was in the beginning exactly the same as it is at present. It is therefore infinitely more probable that this speculation regarding substitutes of material resulting in altered significations of the word is imaginary in its entire range; that is to say, the newly coined word $t s^{\circ} e$, from the days of its childhood, denoted not simply "earthenware,"

the question is here of porcelain is confirmed by the King te chen t'ao lu (JULIEN, Histoire, p. 28). In other passages of the T'ang Annals we meet the regular mode of writing 短器; for instance, in Ch. $4 \mathrm{I}$, p. $4 \mathrm{~b}$, where the porcelain of Hui-ki in Yue-chou (the present province of Che-kiang) is mentioned. In the T*ai piing huan yü ki only the form 登 is employed. "Porcelain" is expressed by 磁 in the Liao shi (Ch. 104, p. 2) and Yüan shi (Ch. 88, p. Io b).

1 The mental process underlying this transformation may be compared with the extension of our word "china" to porcelains made in any countries outside of China. p. 48).

${ }^{2}$ Hirth, Ancient Chinese Porcelain, p. I30 (repeated in his Chinesische Studien, 
but a higher grade of pottery which shared characteristic features with true porcelain.

Another problem is whether the kind of porcelain manufactured at Ts'e-chou bore any relation to the mineral $t s^{\prime} e$. The term $t s^{\prime} e$ 磁, as is well known, is the designation of the magnet or loadstone; but, as admitted by the Chinese, it denotes also another mineral which is suitable for the making of pottery. This fact is brought out by several ancient stone sculptures in the Museum's collection, in the votive inscriptions of which it is stated that the material of the sculpture is $t s^{\prime} e s h i$ 磁石 (" $t s^{\prime} e$ stone"), which, however, as shown by a very superficial examination, is not loadstone. The "Records of the Potteries of King-te-chen" "inform us that "the $t s^{\prime} e$ stone 磁石 is made into a paste serviceable for pottery vessels, but that this stone is not identical with the magnet attracting iron and used for magnetic needles; further, it is a peculiar and distinct kind of stone of white color and of bright and smooth appearance; the vessels made from it are beautiful, but not delicate, and differ from porcelain earth; aside from Ts'e-chou, they are made in Hü-chou 許州 in Ho-nan Province. It is accordingly not magnetic ore which entered into the manufacture of $T s^{2} e$ porcelain, but a mineral of a different nature, as yet undetermined, apparently not discovered prior to the age of the Sung, and likewise styled $t s^{\prime} e .^{2}$ This point is especially mentioned in this connection, because a supposition that magnetic ore might have been mixed with porcelain glaze would not be entirely without foundation. ${ }^{3}$

In fact, however, we have no account of loadstone ever having been used by the Chinese in the making of pottery; and it is therefore impossible to assume any connection between the two words $t s^{\prime} e$, the one denoting "loadstone," the other "porcelain." As the written

${ }^{1}$ King te chen t'ao lu, Ch. 1o, p. 12 b (new edition, I891).

${ }^{2}$ Palladius (Chinese-Russian Dictionary, Vol. II, p. 343) states under this word, "Magnet; suitable for the eyes; employed in the making of bowls and pillows; porcelain."

${ }^{3}$ According to Pliny (Nat. hist., xxxvi, 66, § 192), magnet-stone was added to glass during the process of making the latter, because it was credited with the property of attracting liquefied glass as well as iron (Mox, ut est ingeniosa sollertia, non fuit contenta nitrum miscuisse; coeptus addi et magnes lapis, quoniam in se liquorem vitri quoque ut ferrum trahere creditur). The correctness of this report has been called into doubt. The Arabic mineralogy ascribed to Aristotle has replaced the magnet-stone by the stone magnesia as being added to glass (J. RuskA, Steinbuch des Aristoteles, p. I.7I). In another passage (ibid., p. I29) it is said that glass cannot be finished without the stone magnesia; the latter denotes manganese, which serves for the refinement of glass fluxes. Whether Pliny is guilty of a confusion in the case, or whether he really reproduces a tradition current in his time, can hardly be decided. 
symbols are formed by means of different phonetic elements, the greater likelihood is that also the two words, although now phonetically identi$\mathrm{cal}$, are traceable to different origins. The history of the word $t s^{\circ} e$ 磁 can be established without great difficulty. The earliest form in which it was written is $t s^{\prime} e$ shi 慈石 (that is, "attractive stone"); in this manner we find it, for instance, in the Annals of the Former Han Dynasty. ${ }^{1}$ The character 磁, consequently, is a secondary formation based on a contraction of the words $t s^{2} e$ and shi, the latter assuming the position of classifier, the former that of phonetic element, the original significance of which was bound gradually to disappear. The word for "porcelain," however, is written with the phonetic element $t s^{\prime} e$ 次, which, as an independent word, has the meaning "second, next in order, inferior," etc. It is clear that in composition with the classifier 'clay' (wa 瓦) it has no word-meaning whatever, but has merely the function of a phonetic element. Thus far we are entirely ignorant of how this new word may have arisen in the first centuries of our era. In the Sung period the phonetic part seems to have been altered, for the dictionary $T$ si yün 集 韻, published by Ting $\mathrm{Tu}$ 丁度 in the middle of the eleventh century, records the two forms 㼣 and 甆 as popular or common at that time. This manner of writing may have come about under the immediate influence of the porcelain of Ts'e-chou, which then sprang into existence.

The preceding remarks on the term $t s^{\circ} e$ are not intended to encroach on the domain of the sinologue. No one feels more keenly than myself that a critical and detailed study of this term (not based on the modern cyclopædias, but on the actual source-works) is required, and should be taken up some day by a competent sinologue who has a taste for researches of this kind.

The previous discussions on the origin of porcelain were chiefly based on haggling about terms, which at times assumed an almost Talmudic character. Students entered into the arena with a dogmatic definition fixed in their minds, of what porcelain is or should be, and, according to their personal standpoint, rejected or accepted this or that period at which porcelain should have come into existence. Thus we face the amazing spectacle that from 1856 , the date of the appearance of Julien's celebrated book on Chinese porcelain, down to the present time, almost any period of Chinese civilization has been claimed as the one responsible for its "invention." From its exalted position in

${ }^{1}$ Ts'ien Han shu, Ch. 30 , p. 32 b. By the way, it may be remarked that in A.D. 906 the name of the city Ts'e-chou was changed in writing into 慈州, while in 916 the old character 磁 was restored ( $T^{\prime} a i$ p'ing huan yï $k i$, Ch. 56, p. Io b). 
the Han dynasties proclaimed by Julien, it was relegated to the beginning of the Sung dynasty (A.D. 960) by E. Grandidier; ${ }^{1}$ and all this glory ended in its final degradation into as late a period as that of the Ming. Mr. E. A. Barber, Director of the Pennsylvania Museum in Philadelphia, one of the most serious students of pottery in this country, gives vent to this growing pessimism in the following observation: "The consensus of opinion among conservative students at the present day, after divesting the subject of all sentimental considerations, is that true porcelain first appeared during the Ming dynasty, which would not carry it back of the fourteenth century. No examples of actual porcelain, that can with certainty be referred to an earlier date, are known to collectors; and it is reasonable to suppose that had such ware been produced before that period, some few pieces at least would have survived. Indeed, it is extremely doubtful whether any actual examples antedating the fifteenth century can be found." ${ }_{2}$ Mr. Barber, however, frankly admits that the Chinese themselves have classed all wares which possess great hardness and resonancy (which latter is an indication of vitrification) with porcelain, and that it is true that a porcelanous glaze was used to some extent before the general introduction of semi-transparent bodies. This concession points out that the subject may be viewed from different angles. There is, indeed, a twofold point of view possible and permissible, a European-American and a Chinese one. HoBson, ${ }^{3}$ who possesses a large share of critical ability combined with true common sense and sane judgment, has clearly noticed this diversity. "The quality of translucency which in Europe is regarded as distinctive of porcelain is never emphasized in Chinese descriptions," he observes, and goes on to determine the difference between the Chinese and European definitions of the substance. Now, if this be true, every student capable of objective thinking must admit that it is a logically perverse procedure to read "our" definitions of porcelain into what is called by the Chinese $t s^{\circ} e$, but that for the correct appreciation of this term the Chinese viewpoint exclusively must be made the basis of our investigation. In other words, the point simply is, that we must endeavor to understand what notion in the minds or in the fancy of the Chinese is conveyed by their term $t s^{\circ} e$. If a bit of pottery is styled by the Chinese $t s^{\prime} e$, yet is not true porcelain in our conception of the matter, we are obliged to give the Chinese credit for their appellation, and to get at their mode of reasoning. By rejecting

\footnotetext{
${ }^{1}$ La céramique chinoise, p. I6 (Paris, r894).

2 Hard Paste Porcelain, Part first (Oriental), p. 7 (Philadelphia, I910).

${ }^{8}$ Chinese Pottery and Porcelain, Vol. I, p. 148.
} 
this procedure we deprive ourselves of the opportunity of studying and grasping the development of this peculiar ware. By arguing that in the beginning the term $t s^{\prime} e$ connoted nothing but ordinary pottery, we close our eyes to the real issue, and act like the ostrich; in this manner we utterly fail to comprehend the process of evolution of porcelain. The early $t s^{\prime} e$ has now arisen, and is that ware which is the object of this article. I further make bold to say that in any ancient text down to the T'ang period, where the term $t s^{\prime} e$ may be encountered, it will invariably refer to a porcelain-like pottery which has some relationship to genuine porcelain, and that we shall not err in translating it by "porcelanous ware," or a similar expression. 


\section{HISTORICAL NOTES ON KAOLIN}

A disquisition on the beginnings of porcelain should take regard also of the question as to when and how those elementary materials that compose porcelain made their first appearance. Porcelain is a variety of pottery the body of which consists essentially of two ingredients of earthen origin, that are fired together. These two substances widely occur in nature, and are designated by us with their Chinese names, "kaolin" and "petuntse." The former is a white clay, infusible, lending plasticity to the paste, and forming the body of the vessel. Geologically it originated through a gradual process of decomposition of granite and analogous crystalline rocks. ${ }^{1}$ The latter is a hard feldspathic stone, fusible at a high temperature, constituting the glaze and responsible for its transparency.

The fact that kaolin is used in the composition of Chinese porcelain has been unduly emphasized, or even exaggerated, by European historians of porcelain. Kaolin was heralded as a sort of important discovery, that led to the revolutionizing of the potter's art; and an inquiry into the time when Chinese authors begin to speak of the substance was even taken as a test for the beginnings of porcelain itself. This is not a correct conception of the matter. Kaolin is nothing but a natural clay, not of very unusual occurrence, and, in fact, has been utilized by potters outside of China without resulting in any porcelain-like product. $^{2}$ Kaolin itself cannot make porcelain, and the presence of kaolin in the composition of a certain vessel does not constitute proof of its being porcelain. Kaolin should not be confused with the kaolinite of which it is composed. The mineral

${ }^{1}$ See Prestwich, Geology, Chemical, Physical, and Stratigraphical, Vol. I, p. 48.

2 Thus in India a white earthenware is made from a decaying white granite, which is carefully washed, and kneaded into a clay that produces a porous white ware. ... This clay is in composition the same as the kaolin of China, and is very abundant in India (H. H. ColE, Indian Art in the South Kensington Museum, p. 20I). The Singalese potter (in the same manner as his Chinese colleague during the T"ang period) uses kaolin as a white paint for decorating pottery (A. K. CoomaRaswamy, Mediæval Sinhalese Art, p. 225; see also WatT, Dictionary of the Economic Products of India, Vol. II, p. 364). It is well known that kaolinic deposits are found in England, France, Germany, and North America, and are well known from many other parts of the world. As to America, compare, for instance, the interesting study of A. S. WATts, Mining and Treatment of Feldspar and Kaolin in the Southern Appalachian Regions (Bulletin No. 53 of the Department of the Interior, Bureau of Mines, Washington, I9I3). 
kaolinite is the basis of kaolin, and theoretically pure kaolin would contain nothing but kaolinite; but kaolinite is also the basis of nearly all common clays. In these it is mingled with larger or smaller quantities of various minerals by which its properties are more or less obscured. Hence the chemical examination of almost any burned pottery, even of common bricks and the crudest and cheapest of earthenware, will disclose the presence of derivatives of kaolinite which might be, and as a matter of convenience frequently is, interpreted as due to the presence of small quantities of kaolin, instead of larger quantities of ordinary clay containing kaolinite. It is quite certain that the bodies of many early Han pottery bits contain more or less kaolin or kaolinite, yet they are not porcelains. The utilization of kaolin for potter's work on a large scale is not a "discovery," but rests on experience. It was incidentally found, and its employment was gradually extended through a selective progress in the enrolment of materials.

The distinctive structural character of porcelain is based on the combination of three elements, - a porous, opaque skeleton; a transparent, dense bond permeating the skeleton; and a thin, glassy glaze on the outside, which merges imperceptibly with the body. In typical porcelains the opaque, porous body is kaolin or aluminous derivatives therefrom, which, through their resistance to the effects of heat, supply a rigidity that prevents the ware from deforming in the kiln. Also its opacity clouds the transparency of the other elements to translucency. The kaolin skeleton is permeated and bound together by a more fusible glass or enamel-like substance (petuntse), which makes the ware strong, impervious, and translucent. The glaze serves for the perfection and increased lustre of the surface. Kaolin alone makes a ware which is porous, fragile, and opaque. Petuntse alone softens in the kiln, and runs together into a lump.

For the lover of art the salient and distinctive points in porcelain are the glaze and its organic combination with the body. The body, as a rule, is invisible: it is the glaze that is intended to appeal to the spectator and to convey an esthetic impression.

F. Hirth ${ }^{1}$ was the first to call attention to a statement of the Taoist adept T'ao Hung-king $\left(45^{2-536)}\right.$, to the effect that in his time "white clay" (pai ngo 白惡), or kaolin, was much utilized in painting, ${ }^{2}$

${ }^{1}$ Ancient Chinese Porcelain, p. I3I.

${ }^{2}$ What this means has not been explained by Hirth, who translated, "much used for painting pictures." It cannot be understood, of course, that kaolin was a pigment applied in pictorial art to paper or silk. Technically there are but two possibilities: kaolin may have been utilized in architectural painting for the decoration of walls, being applied to a colored background, or it may have been employed 
and was low in price. This passage is found in the Cheng lei pen $t s^{\circ} a o$, a learned pharmacopœia written by the physician T'ang Shen-wei, and first published in Iro8. This text allows of the inference that porcelain clay was known in the latter part of the fifth or beginning of the sixth century; but I should not go so far as to conclude with Hirth that T"ao Hung-king "would have surely mentioned the use of porcelain earth in the manufacture of chinaware if in his time it had been so used on an extensive scale," and that "in the sixth century, when he wrote, the use of porcelain earth for pottery purposes was unknown." This argument, drawn from the mere silence of a writer, is not conclusive: it seems preferable to think, that, judging from the trend of his mind and the direction of his studies, the author was not at all interested in the subject of pottery. What attracted him were not the artifacts of men, but the substances and wonders of nature, that might reveal healing-properties for the benefit of his suffering fellow-men. Even in speaking of the application of kaolin to pictorial subjects or decorative designs, he does not mean to offer a contribution to technology, but he incidentally drops this remark by way of definition, in order to render himself intelligible to his contemporaries as to the matter under discussion; for he says literally, "This [that is, the white clay here in question] is identical with that now largely utilized in painting, and low in price. Customarily it is but seldom administered in prescriptions." 1 The subsequent works dealing with pharmacology, while they give some notice to porcelain clay on account of its

for the ornamentation of a surface in pottery vessels. The latter process is now well known to us through numerous specimens of the T'ang period. The Pen ts'ao kang $m u$ of Li Shi-chen (section on clays, Ch. 7, p. I) has the reading hua kia yung 畫家用 (instead of hua yung of the Cheng lei pen $t s^{\prime} a o$ ), which means "used by painters."

${ }^{1}$ Hirth pointed out another text in the Cheng lei pen $t s^{\circ} a o$, which, he stated, is quoted from the $T^{\prime} a n g$ pen $t s^{\prime} a o$, the pharmacopœia of the T'ang period, compiled about the year 650. In the edition of the Cheng lei pen $t s^{\circ} a 0$ before me, issued in I523 (Ch. 5, fol. 25), the passage in question, however, is cited from a work styled T"ang pen yü (that is, "Remains of the T'ang Herbal"), and introduced by the words, "The commentary says." I venture to doubt that this work $T^{\prime}$ ang pen yü is strictly identical with the $T^{\prime}$ ang pen $t s^{\circ} a o$ described by BretschneIder (Bot. Sin., pt. I, p. 44), especially for the reason that a quite different extract from the $T^{\text {"ang }}$ pen is quoted in the Cheng lei pen $t s^{\circ} a o$ shortly before this passage, and that in this work quotations from the former are constantly referred to the $T^{\circ}$ ang pen or $T^{\prime}$ ang pen chus (apparently the annotations of the drawings mentioned by Bretschneider). Be this as it may, there is no doubt that the text brought to light by Hirth comes down from the T'ang period. This is also the opinion of $\mathrm{Li}$ Shi-chen, who, in his Pen ts'ao kang $m u$ (Ch. 7, p. $6 \mathrm{~b}$ ), attributes the term "white porcelain vessels" (pai $t s^{\prime} e k^{\prime} i$ ) to the Pen ts" $a$ o of the T'ang. In the text translated by Hirth occurs a clause which he rendered, "During recent generations it has been used to make white porcelain." Hobson (Chinese Pottery and Porcelain, Vol. I, p. I46) has proposed a new translation of this passage, which reads, "During recent generations it has been prepared 
alleged medicinal properties, yet maintain strict reticence in regard to porcelain vessels, though these were positively known at the time of their publication, for the simple reason that this topic was beyond their scope. Neither the Cheng lei pen ts'ao nor the Pen ts'ao kang $m u$ discusses porcelain, but both books are content to recommend prescriptions of kaolin for certain complaints. While Su Kung upholds that of Ting-chou, and Li Shi-chen that of Jao-chou (in Kiang-si), as particularly efficient, this is merely the outcome of a more specialized medical subtlety.

It would likewise be preposterous to assume that T'ao Hung-king is the first author to mention kaolin. On the contrary, he is forestalled by at least one predecessor. The work Pie $l u,{ }^{1}$ which existed prior to his time, as quoted in the Pen ts"ao (l.c.), states that "white clay (pai $n g o)$ originates in the mountains and valleys of the district of Han-tan 耶 鄲, ${ }^{2}$ and that it may be gathered at any season." This restriction to a single locality certainly does not betoken the scarcity of the material, which is indeed common in many localities: it reflects solely the limitations of local experience. Under the Sung we hear from the lips of $\mathrm{Su}$ Sung that this variety of clay was then ubiquitous, and was throughout used by the people for the washing of their clothes. ${ }^{3}$ This view is confirmed by $\mathrm{Li}$ Shi-chen, who observes that white clay occurs everywhere, and is employed for the baking of white pottery vessels. However common the occurrence of kaolin in China may be, the fact

from white ware." From a grammatical point of view this translation is perfectly correct. It is, however, somewhat difficult to understand why the pharmacists of the T'ang period should have extracted kaolin from finished ceramic products, even though it was only from fragments of such, if kaolin could so easily be obtained in nature; or it is conceivable also that kaolin inherent in pottery was vested with more efficient magical and increased healing-power, as it had undergone a transmutation in the furnace. We have to know more about the development of alchemy in China before we may hope to settle many interesting questions and beliefs connected with pottery.

${ }^{1}$ See Chinese Clay Figures, p. 135 , note 4.

${ }^{2}$ It comprised what now forms the two prefectures of Kuang-p'ing and Cheng-te, in the southern part of Chi-li Province, and in particular referred to Ts 'e-chou. In ancient times it was the capital of the state of Chao (Chavannes, Mémoires historiques de Se-ma Ts'ien, Vol. II, p. 92). It is an attractive suggestion of HoBson (l.c., p. 147), that the kaolinic deposits of Han-tan should have supplied material for the Ting-chou potters.

${ }^{3} \mathrm{~K}$ 'ou Tsung-shi, in his Pen ts'ao yen $i$ of I I 16 (Ch. 6, p. Ib; ed. of Lu Sin-yuan), makes the same observation, adding that the substance was made into square blocks sold in the capital under the name "white earth powder" ( pai $t$ " $u$ fen 白士 粉). According to the Ling piao lu $i$ (Ch. A, p. 4; ed. of Wu ying tien) by Liu Sün of the T'ang period, a white and greasy earth was gathered north of the city of $\mathrm{Fu}$ chou 富州 (in the prefecture of $\mathrm{Wu}$-ch'ang, $\mathrm{Hu}$-pei) and traded over southern China, where the women used it as a face-powder. This probably was a kind of pipe-clay. 
remains that this observation is only the result of later periods, and that in times of antiquity the knowledge of it was much restricted, and attached to but few places. The wondrous book of geographical fables, the Shan hai king, mentions it in two passages. One is embodied in the chapter on the "Mountains of the West" (Si shan king 西山 經), saying that on the south side of the mountains of Ta-ts"e there is plenty of clay. ${ }^{1}$ The other contains the notice, in the chapter on the "Mountains of the Centre" (Chung shan king 中山 經), that "in the midst of the mountains of Ts'ung-lung there are many great valleys in which there is plenty of white clay; apart from the latter, there are also black, dark blue, and yellow clays." ${ }^{2}$ Kuo P'o adds that also variegated clay is said to occur. Whether the two texts are of ancient date, I do not venture to decide: they are quoted as early as the Sung period by Su Sung (a distinguished scholar, and editor of the materia medica $T^{\prime} u$ king pen $t s^{\prime} a o$ ), in his discussion of kaolin, which he winds up by remarking that solely the white clay is medicinally employed. Personally I am under the impression that the Shan hai king, in the version which is now before us, is not older than the Han period, and doubtless contains also many post-Han interpolations. I would certainly not base on this work any chronological conclusions as to the term pai ngo.

The Chinese explanation of the term ngo is interesting, because it has led to the formation of a new word. The character 垶 is composed of the classifier 土 ('earth') and the phonetic element 亞. The latter enters also into the formation of the character 惡, which likewise has the sound $n g o$ or $n g u$ ('evil'). Li Shi-chen ${ }^{3}$ is therefore led to the following speculation: "Since the normal color of earth is yellow, white must be considered as an evil color in earth; hence it was called $n g o$ [that is, 'evil earth']. Subsequent generations tabooed this word, and changed it into pai shan 白善 [that is, "the white good one']." The notion of "wicked earth" is elicited by punning, the two words 珪 and 惡 being homophonous. This jocular interpretation must have existed as a popular tradition since ancient times, since the result of it, the opposite term pai shan, is said to have occurred in the Pie lu. K'ou Tsung-shi, whose Pen ts'ao yen $i$ was published in rrr6, styles kaolin "white good earth." This was under the Sung, when the porcelain industry received a powerful stimulus. The term pai shan

${ }^{1}$ 大次之山其陽多聖 (Ch. I, p. 27 b; of the edition printed in 1855 at Shun-k'ing, Sze-ch 'uan). The character 聖, according to the commentary of Kuo P'o (276-324), is to be read $n g u$ (or $n g o$ ), explained as "earth of very white color."

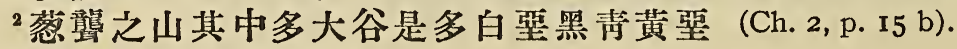

${ }^{3}$ Pen ts'ao kang $m u$, Ch. 7 , p. I. 
白 善 is met with as early as the T'ang period (6r8-906), in the mineralogical glossary Shi yao erh ya 石藥爾雅, compiled by Mei Piao 梅彪 in the period Yüan-ho $(807-82 \mathrm{I}) .^{1} \quad$ Here it is given as a synonyme of kan t'u 甘土 ("sweet earth"), on a par with other synonymes for this term, which are pai tan 白單, tan tao 丹道, and $t^{\prime} u$ tsing 土 精 ("essence of earth"). At an earlier date we find the term shan in the Buddhist dictionary $Y i$ ts'ie king yin $i$ 一切經鬲義, ${ }^{2}$ compiled by the monk Yüan Ying 元 應 about A.D. 649, who explains it as shan $t^{\prime} u$ 善土 ("good earth"), and identifies it with "white clay" (pai t'u 白土) and ngo. The most interesting point is, that this author cites the $W u p^{\prime} u$ pen $t s^{\circ}$ ao 㕦普本草 to the effect that the term pai ngo has a synonyme in the form pai shan 白墠. According to BRETSCHNEIDER, ${ }^{3}$ the $W u p^{\prime} u$ pen is'ao was written by $W u P^{\prime} u$ under the Wei dynasty in the first half of the third century A.D. If the definition, as handed down by Yüan Ying, was really contained in this work, we should have a formal testimony for the knowledge of kaolin in the third century. The case was presumably such, that in the T'ang era, when the excellent qualities of kaolin were first recognized, the transformation of the word took effect, and ultimately resulted in a new character formed with the word shan 善 as phonetic element, and the classifiers 'earth'士 or 'stone' 石. The taboo announced by Li Shi-chen cannot have taken serious dimensions, for the ceramic authors of the Manchu dynasty perpetuated the word ngo, and abstained from the word shan.

In a poem of Se-ma Siang-ju, entitled Tse sï fu 子 虚 賦, ${ }^{4}$ ochre and white clay (che ngo 赫 珪) are spoken of as natural products of Sze-ch "uan. ${ }^{5}$ The attribute "white" is not in the text, which merely offers the word ngo; but Chang Yi 張揖, the author of the dictionary Kuang ya 廣雅, who lived in the first part of the third century A.D.,

1 Reprinted in the collection Pie hia chai (Ch. A, p. 4).

${ }^{2}$ Ch. I7, p. 2 (edition of Nanking). Regarding this work see JuLIEN, Histoire de la vie de Hiouen Tsang, p. xxiii; Wylie, Notes on Chinese Literature, p. 2 I I; Watters, Essays on the Chinese Language, p. 52; Bunyiu Nanjo, Catalogue of the Tripitaka, No. 1605 .

${ }^{3}$ Bot. Sin., pt. I, p. 40.

${ }^{4}$ Shi ki, Ch. II, p. 2 b. The poet died in II 7 B.C.

5 They are likewise mentioned as products of that region (Shu) in the Hua yang kuo chi (Ch. 3, p. I b, ed. of Han Wei ts'ung shu). Under the year 99I there is mentioned in the Sung Annals the pictorial decoration of a palace by means of the same two substances. The same term appears in Lie-tse (WIEGER, Les pères du système taoiste, p. 104), when King Mu built a palace for a juggler, who had come from the farthest west. This chapter of Lie-tse (and probably many others), in my opinion, comes down from the Han period; and this conclusion is confirmed by the term che ngo which does not occur earlier than that time. The work of Lie-tse is first mentioned in the Ts'ien Han shu (Ch. 30, p. I2 b). 
comments on this passage, that ngo has there the meaning of "white clay" (pai ngo), which, he adds, is identical with the term pai shan used in the Herbals (pen ts'ao), so that what he means is doubtless kaolin. Also Yen Shi-ku (579-645), annotating the same word in the Han Annals, states that "it is identical with what is now called "white earth' (pai t'u)." It is interesting that these Confucian scholars of the third and sixth centuries respectively were acquainted with kaolin, thus following suit with their Taoist colleagues; but it appears rather doubtful whether the term, as used in the Annals of Se-ma Ts'ien, can really be credited with the significance "kaolin." There is no other testimony to this effect (leaving aside the dubious Shan hai king) in the Han period; and, be this as it may, the passage in question is not conclusive, the substance ngo being mentioned solely as a product of nature, without any allusion to human exploitation. In the Glossary of the T'ang Annals the term ngo is interpreted as "white earth" (pai t'u 白土). ${ }^{1}$

In the T'ang period, kaolin formed also a desirable article for tribute or taxes to the Court, which certainly means that it was employed in the manufacture of pottery. The $W u t i k i$ 吳地記 (“Records of the Land of Wu"), by Lu Kuang-wei 陸廣微, written at the end of the ninth century, mentions the mountains of Hang 杭山 as hoarding white earth that resembles jade and is very resplendent, and that the people of $\mathrm{Wu}$, who gathered it, sent as tribute under the name pai ngo. ${ }^{2}$

Passing beyond the Han period, we find the word ngo employed in times of antiquity, but in a peculiar sense, quite distinct from the later significance "potter's clay." In the early period it was strictly an architectural term, and implied a function falling within the province of a mason. This ancient significance is acknowledged by the dictionary Erh $y a$, which, in its section concerned with the nomenclature of buildings, states that ngo is the designation for a whitewashed wall; and the dictionary Shi ming 䆁名, by Liu Hi 劉熙 of the Posterior Han, is still more explicit on this point, as evidenced by the annotation that the wall is first raised from mud, and then invested with a coating of lime. ${ }^{3}$ The Shuo wen explains the term as "white plaster" (pai t'u 白涂). The principal office of the word was that of a verb, with the

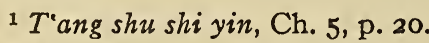

2 According to the Gazetteer of the Prefecture of Su-chou ( $S u$ chou $f u$ chi, Ch. 20, p. I5 b), kaolin is still dug on the Yang-shan near Su-chou to a depth of a hundred feet.

3 先泥之次以白灰飾之出 (Shi ming, section 5, p. 8; ed. of King siin f'ang ts'ung shu or Han weits'ung shu). 
meaning "to plaster or whitewash the floor or the walls of a house." This is particularly evidenced by the verb $y u$ 䁫动 ("to blacken"), its opposite, to which it is closely linked in order to express the performance of a religious ceremony during the period of mourning. The mourner was obliged to dwell in an unplastered earth hut for two years. After the sacrifice in the commencement of the third year, the ground of his cot was blackened, and the walls were whitened,- a rite simply expressed by the compound yu ngo 黝力 丝. ${ }^{1}$ In the same chapter of the "Book of Rites" in which this practice is mentioned, the same word ngo occurs in a somewhat different usage. The dwelling specially erected for the mourner is styled $n g o$ sh $i$ 丝室, a term explained as "a hut made of unburnt bricks or earth pisé and not plastered," and used in the $L i k i$ four times. The mourner was compelled to divest himself of all comfort, and to relapse into the most primitive habitation of early times. The term ngo shi, accordingly, means literally "earth house;" and during the archaic period, ngo designated "loam, mud, or clay fit for building-purposes." Simultaneously, however, it was applied also to chalk or limestone, denoting the process of coating a coarse wall with a layer of white. In this sense it is utilized also by Chuang-tse in regard to the whitening of one's nose. ${ }^{2}$ Since the word ngo, which is still defined by the Shuo wen as "white plaster," originally referred to clay and chalk at the same time, the early Chinese do not seem to have clearly discriminated between the two substances. The term pai ngo, which adopted the meaning "kaolin" in the postChristian era, is still used to convey the notion of "chalk," while a stricter terminology formulates for the latter such compounds as shi ngo 石堅 (“stone clay"), ngo hui 堅灰 (“clay lime"), or pai t'u fen 白土粉 ("white earth powder"). ${ }^{3}$

One point stands out clearly,- that in the archaic period the word ngo signified "loam and chalk used in building," and was appropriate to the activity of the mason, but that it neither denoted potter's clay nor had any relation whatever to the work of the potter. The main point to be borne in mind is, that there is no reference to "white clay" (pai ngo) in any authentic document of the Han period,- a fact thoroughly corroborated by archæological evidence. The "white clay,"

${ }^{1} \mathrm{Li}$ ki, ed. Couvreur, Vol. II, p. 240; translation of LeGGe, Vol. II, p. 192.

${ }^{2}$ Ch. $24, \S 5$; see the edition of L. WIEger, Taoisme, Vol. II, p. 420 . It is notable that the stage-fool still appears in China with his nose whitened; and the figure of an actor represented by a T'ang clay statuette in the Museum collection is thus characterized.

${ }^{3}$ See F. DE MÉly, Lapidaires chinois, p. 99; F. Porter Smith, Contributions towards the Materia Medica of China, p. 58. 
or "kaolin," makes its first appearance in the Pie lu, an early Taoist work of uncertain date, and preserved only by way of quotations in subsequent pharmaceutical literature. This lacune in our knowledge, however, is no matter of great concern for the history of porcelain, for that work contains no allusion to pottery. Chang Yi and Kuo P'o of the third century appear to have been familiar with kaolin; likewise $\mathrm{Wu} \mathrm{P}^{\mathfrak{u}} \mathfrak{u}$, the author of a materia medica under the Wei (p. II 5). The medical literature of the T'ang period is, and thus far remains, the earliest source to convey an allusion to white porcelain produced from kaolin. Prior to that time, this substance seems to have found application chiefly in medicine, and as engobe on pottery. It probably played a rôle also in alchemical experiments. There is every reason to believe that it was the nature-loving and drug-hunting professors of Taoism who first experimented with this clay, and this accounts for the fact that the subject has found its way into the pages of the Shan hai king. What the share of the Taoists was in the initial stages of porcelanous ware, or whether a share in it is due to them at all, we have as yet no means of ascertaining. That they had a share in it, however, is more than probable, since the preparation of clays and glazes is a matter of chemistry; that is, in ancient times, of alchemy (see also p. I42).

It is obvious that no forcible conclusion as to the date of porcelain can be deduced from a consideration of the history of kaolin. It is notable, however, that it was known at least in the third century A.D.; and this chimes in with my dating of the early kaolinic ware in the same period. Once more we see that for the history of porcelain we have to depend on archæological evidence.

It is unfortunately impossible to outline a similar sketch of the history of petuntse, or porcelain stone; but it is not surprising that the Chinese have preserved no historical notes regarding this substance. It is simply a feldspathic rock, for which no other than the general designation "stone" (shi 石) exists. It is a general error to believe that the mass itself is styled by the Chinese "petuntse" (properly, pai tun-tse 白不子), an error chiefly propounded by A. J. C. Geerts. ${ }^{1}$ JULIEN $^{2}$ was somewhat astonished at the expression, saying that the Chinese authors who wrote on porcelain fail to explain the sense of the word tun 木. K'ang-hi's Dictionary does not ascribe to the latter any mineralogical significance; in fact, it has none whatever, and is never used by Chinese writers on mineralogy. The character in question is

${ }^{1}$ Les produits de la nature japonaise et chinoise, Vol. II, p. 376 (Yokohama, 1883).

${ }^{2}$ Histoire et fabrication de la porcelaine chinoise, p. 122. 
merely substituted as an easy and convenient abbreviation for tun 墩, which means, as Giles rightly says, "a square block of stone." The term pai tun-tse, therefore, simply signifies "white briquette," and certainly is one of a purely commercial, not mineralogical character: it relates to the color and shape of these blocks, as they are traded from the places of production to the centres of porcelain manufacture. Our mode of applying the term "petuntse" to the material, therefore, is wrong. The fact that this rock, which enters into the manufacture of porcelain, was roughly known to the Chinese long before the time of this specific employment, cannot reasonably be doubted.

${ }^{1}$ In the second edition of his Dictionary, Giles has justly placed the term "petuntse" under this character (No. I2205). 


\section{THE INTRODUCTION OF CERAMIC GLAZES INTO CHINA, WITH SPECIAL REFERENCE TO THE MURRINE VASES}

We know at present as a fact that glazed pottery first appeared in China during the Han period, and that the process of glazing earthenware was unknown in pre-Han times. The Han potter's art was revolutionized, as we have seen, by the adoption of this new technique, which finally resulted, toward the middle or the close of the third century, in the production of a peculiar porcelanous glaze, the forerunner of true porcelain. Porcelain being universally considered as a truly Chinese invention, the broader question may now be raised, Is the invention of glazing, the technical foundation of porcelain, wholly due to the genius of the Chinese, or was the impetus received from an outside quarter? R. L. HoBsoN ${ }^{1}$ has made the following general reply to this query: "Though supported by negative evidence only, the theory that the Chinese first made use of glaze in the Han period is exceedingly plausible. In the scanty references to earlier wares in ancient texts no mention of glaze appears, and, indeed, the severe simplicity of the older pottery is so emphatically urged that such an embellishment as glaze would seem to have been almost undesirable. The idea of glazing earthenware, if not evolved before, would now be naturally suggested to the Chinese by the pottery of the Western peoples with whom they first made contact about the beginning of the Han dynasty. Glazes had been used from high antiquity in Egypt; they are found in the Persian bricks at Susa and on the Parthian coffins, and they must have been commonplace on the pottery of western Asia two hundred years before our era." I am of the same opinion, that Chinese knowledge of glazing is derived from the West, and propose to discuss this problem on the following pages. I hope to enlist all the available facts in the case, so as to place our theory on a solid historical foundation.

The course of my investigation is as follows. The home of glass, glazed pottery, and faience, was Egypt and the anterior Orient; and the reputation of this ware spread to Rome under the name "murrine vessels." The latter subject, being still of a controversial nature, is of especial importance in this connection, as it shows us the high appreciation and expansion of glazed ware over the Mediterranean area at

${ }^{1}$ Chinese Pottery and Porcelain, Vol. I, p. 8. 
a period synchronous with the coming into existence of this pottery in China. This synchronism is not accidental, but is due to the wide fame and diffusion of this novel process in the Far East. It will then be set forth from Chinese records how the Chinese became acquainted with it in consequence of their contact with the Roman-Hellenistic Orient; how the materials required for the technique were propagated to India, Cambodja, and China, and in what manner they were turned to practical use by the ancient Chinese.

If I venture to dwell here at some length on the much-disputed murrine vases of the ancients, the main reason for this invasion of foreign territory is that this subject seems to me to embody an essential chapter in the history of the art of glazing, which allows us to grasp clearly the significance of its eastward migration. My further line of defence rests on various attempts made by older and more recent authors to interpret the murrine vases as having been Chinese porcelain; and in further vindication I may point to two sinologues who in the first part of the nineteenth century participated in the discussion of this problem,- Joseph Hager and Aber-Rémusat. The former ${ }^{1}$ endeavored to prove in a hardly convincing manner that the substance of which the murrines were made was identical with the jade of the Chinese; while the latter ${ }^{2}$ combated this opinion, and conclusively demonstrated that Chinese nephrite does not at all correspond to the description given by Pliny of the murrine vases. The chief argument which runs counter to this theory, and which has not been stated by Abel-Rémusat, is that ancient Chinese jade objects have as yet not been traced in any country of classical civilization, and that nothing is on record in regard to such a trade, either in Chinese or classical documents. Moreover, the provenience of the murrines, as indicated by Pliny and the Periplus Maris Erythraei, must not be disregarded: they came from Egypt, Persia, and India, and were chiefly productions of Persia. In none of these countries have we any evidence as to the occurrence of Chinese jade pieces in ancient times. ${ }^{3}$

In a study devoted to the beginnings of porcelain in China, in which an attempt has been made to determine more exactly the first appearance of porcelanous ware on Chinese soil, a word may be permitted

${ }^{1}$ Description des médailles chinoises du Cabinet Impérial de France, pp. I50-I68 (Paris, I805).

${ }^{2}$ Histoire de la ville de Khotan, tirée des annales de la Chine et traduite du chinois; suivie de recherches sur la substance minérale appelée par les Chinois pierre de Iu, et sur le jaspe des anciens, pp. I95-208 (Paris, 1820).

' More recently the nephrite hypothesis with reference to the murrines has been reiterated by A. voN NORDENSKIöLD (Umsegelung Asiens und Europas, Vol. II, p. 230). 
with reference to the theory that the murrines might have been porcelain of Chinese origin. This view predominated in Europe for three centuries, till it yielded to still more fantastic ideas in modern times. Jerome Cardan (Hieronymus Cardanus), the Italian mathematician (I5OI-76), is to be regarded as the father of the porcelain theory. In his work "De subtilitate rerum" (Nürnberg, I550, p. II9), he made the assertion, "Sunt autem myrrhina ea, quae hodie vocantur Porcellanea," and supported it by the explanation that they had come to western Asia from China, the country of the Seres, and that whatever does not fit in with them in the description of Pliny became subsequently altered in the manufacture of these vessels. Julius Caesar Scaliger (I484-I558) concurred with him in this opinion, and only reproached his predecessor for having advanced his statement in too timid a fashion. His son, the great scholar Joseph Justus Scaliger (I540-1609), inherited and accepted his father's verdict. Whatever we may think of the view of the two Scaliger, it remains interesting, as it was at their time that porcelain gradually became known in Europe; and this fact may certainly have reacted on the shaping of their opinion.

In the eighteenth and the beginning of the nineteenth century, the old opinion that by "the murrines" should be understood porcelain, was revived by P. J. MARIETte ${ }^{1}$ and by E. H. RolofF, ${ }^{2}$ the latter a physician, whose work is accompanied by notes and additions at the hands of Ph. Buttmann. The theory of Cardanus and Scaliger was here defended afresh and with circumstantial detail, and seemingly with such success that it maintained its place for some twenty-five years, until F. ThIERSCH ${ }^{3}$ brought about the victory of the mineralogical theory, and replaced the murrines of porcelain by murrines of fluor-spar. Roloff and Buttmann based their argumentation pre-eminently on the famous passage of Propertius in which are mentioned "murrine cups baked in the kilns of the Parthians" (murreaque in Parthis pocula cocta focis), that without any doubt refer to ceramic productions. They utterly failed, however, to furnish any exact and logical evidence for their proposed identification of murrines with porcelain, which was merely a preconceived idea, or nothing more than their personal impression in the matter. They argued that this porcelain must have come from the land of the Seres, China, where it is exceedingly

\footnotetext{
1 Traité des pierres gravées, Vol. I, p. 219 (Paris, 1750 ). 1810.

${ }^{2}$ Wolf's and Buttmann's Museum der Alterthumswissenschaft, Vol. II, pp. 519-572,

3 Utber die Vasa murrina der Alten (Abhandlungen der bayerischen Akademie, I835, pp. 443-509).
} 
ancient, and must accordingly have been exported as early as in times of antiquity, and certainly to Persia, whence the murrines were imported to Rome. For a brief period it would have seemed as though the alleged discovery of Chinese porcelain bottles in Egyptian tombs might lend support to such an opinion; but for a long time we have known that the whole story amounts to a not very clever fraud. ${ }^{1}$

When the murrine vases were identified with porcelain, European knowledge of the history of porcelain in China was still in its infancy and of the vaguest character; and if a subject is obscure or little known, speculation is usually rife, and the almost incredible is readily accepted. In I857 BosTock and RILEY ${ }^{2}$ still commented on the murrines, that modern writers differ as to the material of which these vessels were composed; that some think that they were of variegated glass, and others of onyx, but that the more general opinion is that they were Chinese porcelain. The last view has never entirely lost its ground, and still counts adherents in this country. In the "New Standard Dictionary," published by Funk and Wagnalls of New York in I9r3, we read, under the article "murrine vases," "porcelain vases brought from the East to Rome."

The present investigation allows us to settle this problem definitely. It is out of the question that the murrine vessels were Chinese porcelain, since at the time when the former were traded from the Orient to Rome nothing like porcelain existed on this globe. We have seen that ceramic products with porcelanous glaze do not come up in China earlier than the latter part of the third century A.D., and that anything of the character of true porcelain cannot be pointed out before the sixth century. The vasa murrhina, however, are mentioned considerably earlier than these two dates. They were first brought to Rome in 6I B.c. by Pompey, who, after his triumph, dedicated cups of this description to Jupiter Capitolinus. Pompey himself had obtained them from Mithridates. Augustus appropriated a single murrine vessel from the treasure of Queen Cleopatra, which is cited as an instance of his moderation. ${ }^{3}$ In the time posterior to Pompey, the murrines became more frequent in Rome, and aroused a passion for them among the upper four hundred. Classical Roman literature does not make

1 Compare S. Julien, Histoire et fabrication de la porcelaine chinoise, pp. XI-XXII; F. HIRTH, Chinesische Studien, pp. 45-48; N. Rondot, On the Chinese Coins and Small Porcelain Bottles found in Egypt (Journal China Branch R. As. Soc., Vol. XXXII, 1897-98, pp. 66-78).

2 The Natural History of Pliny, Vol. VI, p. 392.

${ }^{3}$ Suetonius, Augustus, 7 I. 
any mention of them; they are foreign to the works of Cicero and Varro, as well as to the poems of Horace, Ovid, and Vergil. Propertius (born about 49 B.C.) is the first to make a distinct allusion to them. They are further mentioned by other poets, like Statius, Juvenalis, and Martialis. Pliny is the only one to give a somewhat more detailed, though insufficient, description. The first centuries preceding and following our era, accordingly, were the period when the murrines formed the fashion of the day in Rome; and porcelain was not then made in China. The Chinese records relative to the Roman Orient and Persia are reticent as to trade in pottery; and the fact remains that in Persia, India, Egypt, Greece, or Rome, has never been discovered a specimen of Chinese porcelain of such age that could lay claim to being regarded as murrine. ${ }^{1}$

In the light of our present knowledge, the porcelain hypothesis must be characterized as a failure, and as being doomed to oblivion. The efforts of the men, however, who formulated their thoughts along this line, have not been entirely futile; for, as it so frequently happens, error will ultimately lead us to the knowledge of truth. The champions of porcelain murrines were quite correct in the pursuit of one point of view, - that the murrines were of pottery, not, as has been asserted, of a mineral substance. Their fundamental error lay mainly in the rash manner in which they jumped at the conclusion that Chinese pottery was involved; while we plainly have to adhere to the fact, transmitted to us by the ancients, that the murrine vessels were wrought in the Empire of the Parthians, and that, as stated by Propertius, they were baked or fired in Parthian furnaces. They were consequently products of Iranian pottery; and the peculiar coloration described by Pliny obviously hints at a beautiful and elaborate glazing which was brought out on those vessels. My thesis, accordingly, is that the famed murrines of the ancients were highly-glazed pieces of Oriental,

1 Even under the Han, the potter's craft, which in that period had without any doubt developed into an art, possessed no more than purely local significance, and merely catered to the home consumption of the small community for whose benefit the produce was turned out. It seems certain that no inland trade in pottery was then developed, still less was there an exportation of the article. It is notable that Se-ma Ts'ien, in his famous dissertation on the "Balance of Trade" (Shi ki, Ch. 3o, translated by Chavannes, Mémoires historiques de Se-ma Ts'ien, Vol. III, pp. 538-604), describing the remarkable efforts of the Han in the second century B.C. toward a regulation of the factors of wealth and commerce, does not make any allusion to potters or pottery as an article of trade. Neither do we meet, in the historical documents of the Han bearing on foreign relations, any mention of such export-ware. The incidental mention by Se-ma Ts'ien of "a thousand jars (kang) filled with pickles and sauces," adverted to also in the T"ao shuo (BusHell, Description of Chinese Pottery, p. 93), is without significance. 
that is, Iranian or Persian and Egyptian, pottery. This conclusion directly results from the documentary evidence which the ancient authors have left us. It will be demonstrated at the same time that the substance murra, of which the murrine vases were made, cannot have been a mineral of any sort.

The Latin word murra (less correctly murrha, myrrha), from which the adjectives murreus (murrheus, myrrheus) and murrinus are derived, was adopted from the Greek morrion (in Pausanias) and the adjectival form murrinos, used in the Periplus. ${ }^{1}$ The real significance of this word is as yet unexplained. Certain it is that it is neither Latin nor Greek, but was handed down from the Orient with the objects which it served to designate. Roloff was the only one to attempt an explanation of the peculiar term by inviting attention to a Russian word, murava, which denotes "glazed pottery." The defenders of the mineralogical hypothesis have naturally rejected this point of view without giving reasons why it should not be acceptable. ${ }^{2}$ Yet this opinion is worthy of serious consideration. If it can be proved that the murrines were glazed pottery vessels, there is a great deal of probability in the conviction that the word murra applies to their most striking feature, the glaze. The Russian word pointed out by Roloff indeed exists. It is recorded in all good Russian dictionaries. VLADIMIR DAL, ${ }^{3}$ the eminent Russian lexicographer, notes it in the forms murava, murava, and mur, with a dialectic variant mürom (or muirom' $\left.{ }^{\prime}\right)$, used in the Governments of Pskov and Tver, and interprets it as the glaze applied to the surface of a pottery vessel. Besides this word, the Russian language avails itself of the loan-word glazur (derived from German Glasur) and the indigenous word-formation poliva for the connotation of the same idea. The words mur and murava, not to be found in any other Slavic or European language, are not derived from any Slavic stem, but, like other Russian culture-words, are borrowings from an Iranian language. The onomasticon of Ancient Iranian is but imperfectly preserved; and the word mura or murra, which has doubtless existed in that language, has not been handed down to us in an Iranian literary monument; although a survival of it, in all probability, is preserved in Persian mōri, mūrì, or mūris,

1 The readings morrinos, myrrinus, also occur (see the edition of B. FABRIclus, pp. 42 and 90); but murrinos merits preference.

${ }^{2}$ F. Thiersch, l.c., p. 457. only).

${ }^{3}$ Dictionary of the Living Great-Russian Language, Vol. II, col. 939 (in Russian

${ }^{4}$ The accent after $m$ is intended to express the palatalization of the labial nasal $m$ (soft or mouillé $m$.) 
meaning "small shells" or "glass beads." 1 The conjecture is therefore admissible, that Greek morrion (aside from its Greek ending) is an Iranian loan-word, and that the Iranian prototype had the significance "glass paste, glaze." 2

The earliest author to speak of murrine vessels is the poet Propertius (born about 49 B.c.), in one of his elegies (IV, 5,26 ), in which a procuress tries to allure an inexperienced lass by promising her all the wealth of the Orient, like purple robes, dresses from Cos, urns from Thebæ in upper Egypt, and murrine goblets baked in Parthian furnaces,-

Seu quae palmiferae mittunt venalia Thebae murreaque in Parthis pocula cocta focis.

The most biased adherents of the mineralogical hypothesis were obliged to concede that mineral vessels could not be understood in this passage: no one would be likely to say regarding a mineral that it is cooked or baked. Nor is it necessary to press the verb coquere into a forced

1 The Persian word min̄a signifies "enamel" and "glass, glass bead, goblet." It is very probably connected with Young-Avestan minav, "necklace, ornament" (Bartholomae, Altiranisches Wörterbuch, col. I I86). The Persian mōrì ("glass bead") is found also in the language of the Abdāl or Täbärji in northern Syria (A. von LE CoQ, Baessler-Archiv, Vol. II, I9I2, p. 234).

${ }^{2}$ Also the Russian designation for Chinese porcelain, farfó $r$, is derived from Iranian. In the allied Slavic languages we have Ruthenian faifúrka, Bulgarian farfor and farforiya, Polish farfura (in dialects faifura; farfurka, farforka, and faforka with the meaning "vessel, plate of stoneware"). The same word is found in NeoGreek as farfuri ( $\phi \dot{a} \rho \phi o v \rho \iota$ ) and in the same form in Osmanli (in other Turkish dialects, farfuru: W. RADLOFF, Wörterbuch der Türk-Dialecte, Vol. IV, col. I9I4). The Russian lexicographer Dal is unable to account for the Russian word, and doubtfully refers it to a Turkish source of origin. E. BERNEKER (Slavisches etymologisches Wörterbuch, p. 279) proposes to derive the Slavic words from Osmanli fagfur, which means "title of the Chinese sovereign; name of a region in China which was celebrated for its porcelain; Chinese porcelain; porcelain in general, vases made from it." It must be understood, however, that this word is not Turkish in origin, but Persian, and was borrowed by the Osmans from the latter language. For a long time we have known that fagfur is the Persian term designating the Emperor of China (D'Herbelot, Bibliothèque orientale, Vol. III, p. 320), and it was d'Herbelot who first pointed out that the Turkish name for porcelain, fagfuri, was adopted from the Persian title fagfur (see also YulE's Marco Polo, Vol. II, p. I48). The older form is pakpur or pakur (in the form Pakurios preserved by Procopius, the Byzantine historian of the sixth century, in his De bello persico, I, 5). Masudi (translation of A. SPRENGER, Vol. I, p. 326) was familiar with the correct significance of the term, explaining it as "Son of Heaven." It is accordingly a literal rendering of the Chinese title T'ien-tse ("Son of Heaven"), claimed by the sovereigns of China since times of old, the ruler receiving his mandate from the supreme deity Heaven and governing the world in his name. Persian fag is evolved from bagh (corresponding to Sanskrit bhaga), and signifies "God" ("Bagdãd" signifies "gift of God"); Persian für, būr (Sanskrit putra) means "son." Also in Persian, fagfūri chīn $\bar{\imath}$ and fagfūrī relate to Chinese porcelain. 
meaning, so as to conform it with a process to which a mineral could be subjected; for, as has been shown by H. BLÜMNER, ${ }^{1}$ it is the verb utilized in regard to the burning or baking of bricks and all fictile ware in general.

The fundamental passage in Pliny relative to the murrine vessels runs as follows:-

"The Orient sends the murrine vessels. They are found there in several localities which otherwise have no special reputation, ${ }^{2}$ for the most part in places of the Parthian Empire; excellent ones, however, in Carmania. The opinion prevails that the humidity ${ }^{3}$ contained in these vessels is solidified by subterranean heat. In size they never exceed the small sideboards (abaci); in thickness, rarely the drinking-vessels, which are as large as previously mentioned. Their brightness is not very powerful, and it is a lustre rather than brilliancy. Highly esteemed, however, is the variety of colors, with their spots changing into shades of purple and white; these two tinges, again, result in a third hue resplendent, through a sort of color-transition, as it were, in a purple or milky red. Some laud profusely in them the edges and a certain iridescence of the colors, such as are visible in the rainbow. Others are pleased by oily spots: translucency or pallor is a defect, and likewise are salt grains and warts, which are not projecting, but which, as in the human body, are depressed. Also their odor is commendable." 4

The account of Pliny is vague. One point is conspicuous and quite certain, that he had no opinion of his own to offer on the subject. As illustrated by the application of such phrases as "putant, sunt qui, aliis placent," he simply reiterates second-hand information which he had picked up from unnamed sources, most probably from oral accounts circulated by traders in the article. Most likely, these stories were

1 Technologie und Terminologie, Vol. II, pp. I9, 44.

2 Or, in little-known localities.

3 There is no reason to take the word umor, as has been done, in the sense of "moist substance."

"Oriens myrrhina mittit. Inveniuntur ibi pluribus locis nec insignibus, maxime Parthici regni, praecipua tamen in Carmania. Umorem sub terra putant calore densari. Amplitudine numquam parvos excedunt abacos, crassitudine raro quanta sunt potoria. Splendor est iis sine viribus nitorque verius quam splendor. Sed in pretio varietas colorum subinde circumagentibus se maculis in purpuram candoremque et tertium ex utroque, ignescente veluti per transitum coloris purpura aut rubescente lacteo. Sunt qui maxime in iis laudent extremitates et quosdam colorum repercussus, quales in caelesti arcu spectantur. Iam aliis maculae pingues placent - tralucere quicquam aut pallere vitium est - itemque sales verrucaeque non eminentes, sed, ut in corpore etiam, plerumque sessiles. Aliqua et in odore commendatio est (XXXVII, 8, $\S \S 2 \mathrm{I}, 22$ ). 
directly imported from the Orient, together with the ware. This assumption is a necessary postulate in the case; and it is evident also that Pliny was ignorant of the real nature of the murrines, for he neglects to state what their actual character was. He fails to give a plain and matter-of-fact definition of the material, or to classify it in any known category of objects. True it is, he placed his article in his book on stones; but this only justifies us in concluding that Pliny regarded the murrine vases as possibly of stone, but not that they really were of stone. The opponents of the pottery theory forget that pottery is composed also of mineral substances, that we ourselves speak of stoneware, and that many a piece of stoneware is so hard that it is difficult enough to distinguish it from stone. Pliny must have been in the same quandary, and therefore did not commit himself to a frank utterance. This attitude of restraint is conclusive, and at the outset is conducive to two inferences. The substance murra was neither a mineral nor pure glass, for both were perfectly familiar to Pliny and his contemporaries. Why, if the murra plainly was of a mineral nature, should the learned and experienced naturalist not have unequivocally avowed this fact? The murra can have been but a most striking and novel material, which heretofore had been foreign to the Romans, and which, owing to the very novelty of its character, greatly puzzled them.

Pliny discusses in this chapter the murrine vessels, as they were sent to Rome from the Orient, in the shape of manufactured articles. In the preceding chapter he dilates on their first introduction and their excessive valuation, and tells of renowned individual cups. Naturally he is now bound to say what these sensational and luxurious objects looked like. He certainly does not intend to describe here the substance murra, alleged by some interpreters to have been a species of stone. The same interpreters, however, are agreed that in Chapter 7 the word myrrhina (eadem victoria primum in urbem myrrhina invexit) refers to murrine vessels, and not to the mineral of which they are alleged to have been made; and it is therefore obvious, also, that in the beginning of Chapter 8 the same word, myrrhina, must refer to exactly the same murrine vessels. Pliny means to convey the meaning that the murrine vessels came to Rome from the East. According to ThIERsch, it was not the vessels, but the mineral, which was imported; but unfortunately he fails to inform us where and how the mineral was wrought. Pliny does not say that the vessels were carved in Rome from an imported substance, but he does plainly state that they were first brought to the metropolis by Pompey. ThIERsch ${ }^{1}$ 
sets forth the opinion that Pliny opens the description of the "mineral" by speaking of its size and thickness, then passes on to the description of the surface, its brightness, its colors and their play, and winds up with remarks on the properties of the mass. It would be impossible to unite more absurdities in a single sentence. The dimensions, according to Thiersch, are exactly stated by the terms amplitudo and crassitudo; and the murra was a mineral, and, as Thiersch insists, fluorspar. This mineral, consequently, was quarried in regular blocks of constantly equal dimensions, - a really astounding feat! Fluor-spar or fluorite crystallizes in the isometric system, commonly in simple cubes; this fact could not have escaped Pliny, had he ever had an opportunity of examining this mineral, which is not at all mentioned by him nor by any other ancient writer. ${ }^{1}$ There is, moreover, no evidence that fluor-spar occurs in Persia, where the murrine vessels were made. There is no evidence that fluor-spar vessels were ever turned out in Persia, and, above all, no such vessels have ever come to light among classical antiquities. They did not survive, because they never existed, save in the imagination of nineteenth century writers. $^{2}$ But does our Pliny, indeed, speak of any mineral? There

1 See this volume, p. 62 .

2 Thiersch himself is not the originator of this fancy. He attributes (p. 495) the germ of the idea to an English scholar signing himself "A. M." in the Classical Journal of I810 (p. 472), who, after having seen vases carved from fluor-spar of Derbyshire in his time, persuaded himself that the murrine cups should have been composed of the same material,- an opinion presented without an iota of evidence. According to the Encyclopædia Britannica (Vol. X, p. 578), F. CorsI, the eminent Italian antiquary, held that fluor-spar was the material of the famous murrine vases; Corsi, however, followed Thiersch. H. BLÜMnER (Technologie, Vol. III, p. 276), reviewing the various opinions, observes that this theory has recently been strongly contested; he himself believes in the mineral character of the vessels, for which weak arguments are given. It is astounding with what high degree of tenacity the unfounded opinion of fluor-spar vessels could hold its position in the face of the bare fact that no such vessels ever existed in ancient Persia, Egypt, or in classical antiquity, and have never come to light. GuHL and Koner (Leben der Griechen und Römer, p. 699, 6th ed., I893) adhere to this explanation, and, while admitting that we do not possess vessels which can positively be identified with murrines, point to a semi-transparent bowl found in Tyrol in 1837 , which should probably be one. This supposition, however, conflicts with the fact that the murrines were not at all transparent, as shown by a distich of Martial (Iv, 86): Nos bibimus vitro; tu murră, Pontice: quare! prodat perspicuus ne duo vina calix. In the Century Dictionary it is justly remarked under "murra," "The principal objection to this theory is that no fragments of fluor-spar vases have been found in Rome or its vicinity." M. BAUER (Edelsteinkunde, 2 d ed., p. 653) sensibly states that there is no positive and sufficient evidence for the allegation that the murrines were of fluor-spar; but neither is there any more evidence for his own opinion, that they may have been of chalcedony quarried in Ujjain in India. E. BABELON (in Daremberg and Saglio, Dictionnaire des antiquités grecques et romaines, Vol. II, p. I466) says, "Nous ne savons pas sûrement ce qu'était cette matière précieuse qui servait 
is no sense in speaking of dimensions with reference to a raw mineral. Certainly nobody would compare the size of a mineral with a piece of furniture, and its thickness with a drinking-cup. The use of the word potoria demonstrates that our author, alluding to the costly vessels mentioned in the previous chapter, understands drinkingvessels likewise in this passage.

Any one who has had any experience in reading Chinese texts relative to pottery or porcelain will be deeply struck by a certain kinship or affinity of terminology that prevails in the latter and in the Plinian tradition of murrines. No statement or attribute used in this text contradicts the opinion that ceramic stoneware is here in question. On the contrary, some words, indeed, are as well chosen as though they were directly derived from a ceramist's vocabulary, and are well apt to uphold my theory. The effect of the changing colors produced by the heavy glaze could not be better described than by Pliny's style. Every lover of Chinese pottery who reads this passage intelligently will confess that he has many times had this delightful experience of observing color changes and transitions, as well as the rainbow iridescence which we so greatly admire in the ceramic productions of the Han. Translucency as a defect is intelligible only in pottery: it refers to a thin glaze that allows of the transparency of the clay body. "Oily spots" (maculae pingues) is a felicitous ceramic expression; likewise is "salt grains and warts."

à fabriquer les célèbres vases murrhins. La description quelque peu obscure que Pline donne des vases murrhins . . . est entremêlée de fables et elle ne s'adapte parfaitement bien ni à des coupes d'agate ou de sardonyx, ni à des coupes d'ambre ou de pâtes vitreuses, ni enfin à des coupes de jade, comme le pensent quelques critiques." Leaving aside the vitreous pastes, this statement is perfectly fair.L. De Launay (Minéralogie des Anciens, Vol. I, p. 85) quotes a writer on onyx as saying, that, despite the similarity of descriptions, the murrines were not of onyx or sardonyx: "Si l'une ou l'autre de ces pierres avait été le murrhinum, les Anciens auraient certainement donné aux vases murrhiens, le nom de vases d'onyx ou de sardonyx, au lieu qu'ils ont distingué expressément les vases murrhiens d'avec ceux faits de l'une, ou de l'autre des pierres susdites." "The onyx has been proposed, but our authorities plainly imply that the onyx was a material akin to but yet distinct from that here in question" (W. SmiтH, Dictionary of Greek and Roman Antiquities, Vol. II, p. I82). Other speculations in regard to the murrines were advanced, to the effect that they were made of a gum, or formed from shells. Others referred to obsidian. Veltheim proposed Chinese soapstone. "No mineral has been suggested which answers exactly to Pliny's description, and at present the problem is unsolved" (Sмiтн, l. c.), - sufficient reason for assuming that Pliny's description does not answer to any mineral.

1 The sales (this is the only passage in Pliny where sal is used in the plural) were presumably identical with what the Chinese ceramists praise in the Ting porcelain of the Sung period, which exhibited vestiges of tears (JuLIEN, Histoire, p. 6I); those with tear-marks were even considered as genuine (Ertel, China Review, Vol. X, p. 3II, and Vol. XI, p. I77; HIRTH, Ancient Chinese Porcelain, p. I4I). 
As regards the pleasant odor which Pliny accredits to the murrines, this is intelligible only if the question is of pottery; scented minerals or glass are not conceivable. We are informed by Athenæus (XI, p. 464 b) that the clay in the ceramic export-ware of Koptos in Egypt was blended with aromatics before the process of baking; and Aristotle follows him in this account. In the Greek papyri of the second century A.D. are mentioned fragrant vessels ( $\epsilon \dot{v} \omega \dot{\delta} \eta \kappa \epsilon \rho a ́ \mu l a)$ which were possibly turned out in this manner. ${ }^{1}$

In the two chapters following the one in question, Pliny deals with crystal: the introductory sentence contains a reference to the murrines. He adopts the popular notion that crystal is a sort of petrified ice, and occurs only in cold regions where the winter snow freezes intensely. ${ }^{2}$ A cause opposite to the one producing the murrines, accordingly, makes crystal which assumes form through a process of somewhat vehement congelation. ${ }^{3}$ This observation hints at the previous sentence, "Umorem sub terra putant calore densari." The murrines are a product of heat, crystal is that of cold. This remark shows that murrines and crystals are not allied, but adverse substances; and this contrast believed to prevail between the two may be one of the reasons why they formed a favorite compound of speech.

Passing on to a discussion of amber, our author informs us that this natural product takes rank next among articles of luxury, though the demand for it is restricted to women, and is held in the same regard as precious stones; but whereas no evident reason can be conceived for this appreciation of amber, the reason is manifest for the two former substances, the crystal vases lending themselves to cold beverages, the murrine vases to hot and cold ones alike. ${ }^{4}$ The former notion

1 T. ReIL, Beiträge zur Kenntnis des Gewerbes im hellenistischen Ägypten, p. 4I (Leipzig, 19I3). A reddish, odoriferous clay (Portuguese and Spanish búcaro, Italian bucchero) was much in use for pottery during the eighteenth century.

2 This does not restrain him from stating immediately that the Orient sends crystal, and that none is preferred to that of India. The Buddhist monk Yuan Ying ( $Y i$ ts'ie king yin $i$, Ch. 22, p. 2; see above, p. 115) was more discriminative on this point. Speaking of rock-crystal, and mentioning the theory that it should originate from ice a thousand years old, he points out that there is no ice in the scorching heat of India, and that accordingly Indian rock-crystal is not a transformation of ice, but merely a kind of stone. See also T'oung Pao, 1915, p. 190. $\S 23)$.

3 Contraria huic causa crystallum facit, gelu vehementiore concreto (xxxvir, 9,

${ }^{4}$ Proximum locum in deliciis, feminarum tamen adhuc tantum, sucina optinent, eandemque omnia haec quam gemmae auctoritatem; sane priora illa aliquis de causis, crystallina frigido potu, myrrhina utroque; in sucinis causam ne deliciae quidem adhuc excogitare potuerunt (xxxvir, II, § 30 ). Compare J. H. Krause, Pyrgoteles, p. 90. The passage is somewhat equivocal, owing to the uncertainty as to what omnia haec is intended to refer. It may point to the various kinds of 
directly results from the supposed cold nature of crystal; and murra, being the outcome of heat, must be well adapted for holding hot drinks, or, as the case may be, for cool liquids. The distinction here made by Pliny seems to me to add another weight of proof adverse to the opinion that the murrines were of stone; it is not probable, at least, that any stone cups served for hot beverages, while pottery, and heavily glazed pottery in particular, is a material well suited to such a purpose.

Aside from the main chapter, Pliny devotes a brief sentence to the subject (XXXIII, 2, $\S 5$ ), in his notice on gold, by saying that "from the same earth [where gold and silver are mined] we dug up murrine and crystal vessels, the very fragility of which is deemed to enhance their price" (murrina ex eadem tellure et crystallina effodimus, quibus pretium faceret ipsa fragilitas). The passage has materially contributed to the notion that murra, in the same manner as crystal, should be a natural substance extracted from under the ground. "Here," F. Thiersch (p. 460) remarks, "crystallina evidently does not mean crystal bowls and cups, since the latter are not dug out of the soil, but crystal masses from which they are made; and for this reason the parallelism of the words murrina et crystallina, as well as the application of effodere and invenire, compel us to assume that murrina is likewise used in Pliny with regard to the substance of the vessels, the murra; and Pliny means to say that the murra, in the same manner as crystal, is found beneath the earth and dug up." This conclusion is artificial, and by no means cogent. We all know that not only minerals, but also objects manufactured by human hand, are dug up from the soil; and there seems no valid objection why Pliny's words could not be construed to mean that murrine and crystal vases have been turned up from the soil as the result of excavations. This was not necessarily Pliny's own opinion, but it may have been the outcome of a story transplanted directly from the Orient; and in part this report may well have had a foundation in fact. The passage may signify also that the mineral substances employed in the manufacture of the murra were dug up from the soil. It must be directly connected with the sentence, "Umorem sub terra putant calore densari," discussed above. The pottery vessels were baked in an underground kiln,

amber, as has been translated above; or to the previously mentioned murrines and crystals, with the inclusion of amber. The following priora illa would seem strongly to favor the latter point of view. In that case, Pliny would say that murrines, crystal, and amber enjoy the same consideration or esteem as precious stones. It cannot be read, of course, into this context, that the three materials were classified among gemmae, and that for this reason murra was a precious stone; on the contrary, the passage means that this in fact was not the case, and only that the three were regarded as of the same value as precious stones. 
where the humidity of the clayish substance was solidified by artificial heat, and thus they were extracted from the soil (e tellure effodimus); or the vessels, after being perfectly finished, were intentionally buried under ground to produce an oxidation of the glaze, which resulted in that well-known iridescence and the rainbow colors accentuated by Pliny. Much ado has been made by the adherents of the mineralogical hypothesis about the juxtaposition of murrine and crystal vases in the relevant passage and in another to be cited presently: this fact has been regarded as one of the strongest bulwarks of the mineralogical defence, which, however, is purely illusory. The union of the two products, previously alluded to, was mainly dictated by commercial considerations, since both were received from the Orient: this is the opinion of Pliny, and no other motive guided him in the choice of this expression. On concluding his chapter devoted to the murrine vases, he passes on to the topic of crystal, and notes that "the Orient likewise sends us crystal, that of India being preferred, and it originates likewise in Asia." $\quad$ The clause "oriens et hanc mittit," owing to the addition of the particle "et," forcibly points to the beginning of the preceding chapter, "Oriens myrrhina mittit." For the reason that the Orient despatched murrine as well as crystal vessels, they were enumerated and discoursed in close succession and combined in speech into a compound of pleasing rhythm. There is no valid reason why we should conclude, that, because the names of the two products are allied, the murrine vases must have been of mineral character. ${ }^{2}$ Similar compounds are found in all languages without giving rise to such forced conclusions. We are wont to speak of the tea and porcelain of China as the most characteristic products reaching us from that country; but no one means to imply that tea must be a substance related to porcelain, or that porcelain must be a kind of tea. The Chinese couple jade with porcelain to denote objets de vertu worthy of the collector, and the substances with which both are concerned are as congenial as murrines and crystal. And who will guarantee that the crystal vases shipped from the Orient, according to Pliny, were all of real rock-crystal? They may have been partially of glass as well. ${ }^{3}$

The price of the murrines was enhanced by their frailty, - again an attribute that thoroughly fits pottery, and most assuredly is not

1 Oriens et hanc mittit, quoniam Indicae nulla praefertur; nascitur et in Asia (xxxviI, 9, §23).

${ }^{2}$ We shall meet the same alliance in the Chinese texts relative to the Hellenistic Orient, where crystal (including also cut glass) and faience were closely joined in architecture.

${ }^{3}$ H. BlüMner, Technologie, Vol. III, p. 250, note 6. 
applicable to agate, fluor-spar, or any other stone with which these vessels have thoughtlessly been identified. The murrines were fragile and delicate: Pliny adduces several examples testifying to this fact. A man of consular rank used to drink from a murrine cup, and, from sheer love of it, wore out its edge, resulting in an upward tendency of its value. This good man surely did not possess iron teeth to break through an agate or onyx cup. Pliny himself beheld the broken fragments of a single cup, and tells the story of T. Petronius, who, on the verge of death from his hatred of Nero, broke a murrine basin ${ }^{1}$ of great value. In another passage Pliny observes, "With all our wealth, we even at present pour out libations at sacrifices, not from murrine or crystalline vessels, but from plain earthenware ladles." 2 This sentence occurs in the introductory part of a chapter dealing with works in pottery; and the contrast intended by the author between the rustic, unglazed, indigenous Italic earthenware and the pretentious, glazed, imported Oriental pottery is self-evident. The same discrimination is insisted on in the further discussion of the subject when Pliny, expanding on the exorbitant prices paid for fictiles, laments that luxury has arrived at such a height of excess as to make earthenware sell at higher rates than murrine vessels. ${ }^{3}$ This comparison cannot be construed, as has been done by THIERSCH, ${ }^{4}$ as favoring the opinion that the murrhina were fundamentally different from fictilia, but it is intelligible only when both were productions of a cognate nature.

Finally, Pliny enumerates murrines among the most valuable products derived from the interior of the earth, on a par with adamas (the diamond), smaragdus, and precious stones. ${ }^{5}$ H. BlüMNER ${ }^{6}$ regards this text as furnishing strong evidence in favor of the murrines being stones. In my opinion it is of no consequence. Also the passage relating to white glass in imitation of murrines ${ }^{7}$ is unimportant for our purpose; but it proves at least that the real murrines cannot have been purely of glass, as has been supposed by some authors.

1 Trulla myrrhina, explained also as a ladle or scoop.

${ }^{2}$ In sacris quidem etiam inter has opes hodie non murrinis crystallinisve, sed fictilibus prolibatur simpulis ( $x x x v, 46, \S \mathrm{I} 58$ ). $\S \mathrm{I63)}$.

${ }^{3}$ Eo pervenit luxuria, ut etiam fictilia pluris constent quam murrina (ibid.,

${ }^{4}$ L. c., p. 470.

${ }^{5}$ Rerum autem ipsarum maximum est pretium in mari nascentium margaritis; extra tellurem crystallis, intra adamanti, smaragdis, gemmis, myrrinis (xxxvII, 78 , $\S 204)$.

'Technologie, Vol. III, p. 276.

${ }^{7}$ Pliny, xxxvi, 67, § 198. 
Hitherto the attempt has been made to extract the realities from the ancient traditions, and to interpret them without prejudice. It is more difficult to correctly judge the legendary ingredients by which they are incrusted, as we are unaware of the lore of the Orient which prompted such notions as are echoed in Pliny. An analogous field, however, might contribute a little to aid us in understanding some of this folk-lore. Nothing could better enlighten Pliny's account of murrines than a remembrance of the first experience which Europe had in regard to the newly-introduced Chinese porcelain. If the ancients were deeply impressed and perplexed by the thickly glazed faience of the anterior Orient, and may have mistaken it for stone, an interesting parallel is offered by the fact that in the inventory of the Duke of Anjou (I360-68) is found "une escuelle d'une pierre appelée pourcellaine," and, in that of Queen Jeanne d'Evreux (I372), "un pot à eau de pierre de pourcelaine." ${ }^{1}$ In these two cases, Chinese porcelain (corresponding to that of the Yüan period, r260-1367) is styled "a stone called porcelain."

The beliefs of the ancients in an underground substance from which the murrine vessels were made, receive a curious parallel from the fantastic notions entertained by early European writers as to the composition of Chinese porcelain. BARBOSA ${ }^{2}$ wrote about I $_{5}$ I6, "They make in this country a great quantity of porcelains of different sorts, very fine and good, which form for them a great article of trade for all parts, and they make them in this way. They take the shells of sea-snails, and egg-shells, and pound them, and with other ingredients make a paste, which they put underground to refine for the space of eighty or a hundred years, and this mass of paste they leave as a fortune to their children." In I615, Bacon said, "If we had in England beds of porcelain such as they have in China, which porcelain is a kind of plaster buried in the earth and by length of time congealed and glazed into that substance; this were an artificial mine, and part of that substance" . . . Sir Thomas Browne, in his "Vulgar Errors" (I650), asserted, "We are not thoroughly resolved concerning Porcellane or China dishes, that according to common belief they are made of earth, which lieth in preparation about an hundred years underground; for the relations thereof are not only divers but contrary; and Authors agree not herein" . . . These fables were refuted at the end of the sixteenth and seventeenth centuries by travellers who had occasion to make observations on the

1 F. Brinkley, Japan and China, Vol. IX, Keramic Art, p. 37 I (London, 1904).

${ }^{2}$ YULE and BurNelL, Hobson-Jobson, p. 726. 
spot. Juan Gonzalez de Mendoza, ${ }^{1}$ who wrote in ${ }^{5} 85$, reiterated Barbosa's story, and (in the early English translation) called its validity into doubt; for, if it were true, the Chinese, in his opinion, could not turn out so great a number of porcelains as is made in that kingdom and exported to Portugal, Peru, New Spain, and other parts of the world. ${ }^{2}$ J. NeuHor, ${ }^{3}$ who accompanied the embassy of the East India Company of the Netherlands to China from I6 655 to I $_{57}$, scorns the "foolish fabulists of whom there are not a few still nowadays who made people believe that porcelain is baked from egg-shells pounded and kneaded into a paste with the white of an egg, or from shells and snail-shells, after such a paste has been prepared by nature itself in the ground for some hundred years." The Jesuit, L. LE Compte, ${ }^{4}$ rectified this error by saying that "it is a mistake to think that there is requisite one or two hundred years to the preparing of the matter for the porcelain, and that its composition is so very difficult; if that were so, it would be neither so common, nor so cheap." These two authors were seconded by E. YsBrants IDEs. ${ }^{5}$ The analogy of the beliefs in the origin of murrines and porcelain is striking; and this fancy has doubtless taken its root in the Orient, whence crafty dealers propagated it in the interest of their business. ${ }^{6}$

It would be presumptuous on my part to state positively what class of Oriental pottery should be understood by the murrines. The decision of this question must be reserved for the specialists in this field. Students of ancient ceramics seem to have already had a premonition of the identity of murrines with pottery. ${ }^{7}$ It may be permissible to point,

${ }^{1}$ History of the Great and Mighty Kingdom of China, Vol. I, p. 34 (Hakluyt Society, 1853).

2 This refutation of Mendoza, however, is not contained in the Spanish original, where it is said only, "Y esto fe a visto, y es mas verosimil que lo que dize cierto Duardo Barbosa, que anda en Italiano, que se haze de caracoles de mar, los quales se muelen, y los meten debaxo de tierra a afinarse 100 años, y otras cosas que açerca desto dize. La muy fina, nunca sale del Reyno, por que se gasta en seruicio del Rey, y Gouernadores, y es tan linda que parece de finissimo cristal. La mas fina, es la que se haze en la Prouincia de Saxij" (I. Gonzalez DE Mendoça, Historia de las cosas mas notables, ritos y costumbres, del gran Reyno dela China, p. 25, Roma, 1585). Saxij refers to Kuang-tung.

${ }^{3}$ Gesantschaft der Ost-Indischen Gesellschaft, p. 96 (Amsterdam, 1669).

${ }^{4}$ Memoirs and Observations made in a Late Journey through the Empire of China, English translation, p. I58 (London, 1697).

5 Driejaarige Reize naar China, p. 165 (Amsterdam, I 7 Io).

- E. Kaempfer (History of Japan, Vol. II, p. 369) alludes to another superstition prevalent in his time (end of the seventeenth century), that human bones should form an ingredient of China ware.

7 E. Fourdrignier, Les étapes de la céramique dans l'antiquité (Bull. et Mém. de la Soc. d'Anthr., 1905, p. 239); he gives his opinion with great reserve, however. 
en passant, to a remarkable find of pottery which offers a fair guaranty of being identical with the murrine vases.

F. Petrie's discovery in I909-10, at the south end of Memphis, of kilns for baking glazed pottery, with a large number of fragments of vessels, felicitously fills a gap in the early history of glazed ware, and speaks in favor of the presence on Egyptian soil of murrine vessels, and particularly even of Parthian murrine vessels. The date of Petrie's finds is calculated at a period between A.D. I and 50 , a fragment of a lamp of known type permitting this conclusion. ${ }^{1}$ The principal tints of the glazed shards, which are remarkable for their coloring and their design, are a deep indigo blue, lighter blues, manganese purple, and apple green. The designs are almost entirely Persian, showing little, if any, direct Greek influence. Winged bulls, rampant beasts, "sacred tree," etc., all occur; and the problem arises whether this Persian character points to some Oriental revival of the art of making glazed pottery. In Diospolis, according to the Periplus, ${ }^{2}$ murrines were imitated in glass; and this imitative manufacture presupposes the existence there of true pottery murrines which were taken as models. The Memphis pottery of Persian style due to Petrie perfectly answers this purpose, as to both its technical properties and its chronology.

Among Greek authors, the murrines are mentioned only by Pausanias and the Periplus. Pausanias (second century A.D.) recalls them merely in a passing manner. In the Arcadica (XVIII, § 5) he speaks of "glass, crystal, murrine vessels, and others made by men from stone." 3 The idea that Pausanias speaks of vessels carved from stone is thoroughly excluded; he hints, on the contrary, at vessels turned out from products and devices of human labor. "Crystal" is probably nothing but cut glass; the union of the terms "crystal" and "murra" has already been discussed. "Glass" indeed belongs to the same category as "murra;" and the passage of Pausanias is sanely interpreted by the rendering, "glass, cut glass, and glazed pottery, and other products made by men from stone."

In the Periplus Maris Erythraei, written approximately about A.D. $85,{ }^{4}$ the murrines are mentioned in three passages. In Chapter VI

${ }^{1}$ Compare O. M. Dalton, Byzantine Art and Archæology, p. 608.

${ }^{2}$ See below, and p. 138 .

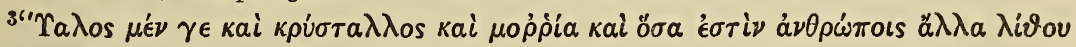
тосои́ $\mu \in v a$.

${ }^{4}$ Compare the writer's Notes on Turquois in the East, p. 2, note. J. KENNEDY (Journ. Royal As. Soc., I9I6, p. 835) is now inclined to date the Periplus at about A.D. 70. 
we meet "several kinds of glass and other murrine vases, which are made in Diospolis." 1 The latter city is regarded as identical with Thebæ in upper Egypt. Here the substance murra is designated as a kind of glass, but it is "another" kind of glass, different from ordinary glass. There is no doubt in my mind that it denotes here the vitreous paste employed for the glazing of pottery, and this conclusion perfectly agrees with all that we know about the thriving industries of ceramics and glass in Egypt of that period. ${ }^{2}$

Chapter XLVIII of the Periplus mentions the trade of Ozene,that is, Ujjayinī (Ujjain), - the chief city of Mālvā, in India, whence onyx-like and murrine stones ${ }^{3}$ are brought to the port Barygaza on the west coast. In the following chapter it is stated that these articles, among others, are exported from Barygaza. Again, in this case, we have not to understand by the murrine material a pure mineral of uniform character, but an artificial composition of partially mineral origin, turned to glazing-purposes, and introduced into commerce in the shape of cakes, which, on the surface, appeared to the uninitiated as a mineral substance resembling onyx. The Periplus thus opens our eyes to the fact that substances for glazing were traded as far as India, and this is confirmed both by Indian traditions and by the Chinese annals.

The Chinese, indeed, were acquainted with the murra of the ancients; and Chinese records point in the same manner to the home of the substance, - the anterior Orient, styled by them $\mathrm{Ta} T \mathrm{~T}$ " in ("Great Ts in"). The glassy paste for the production of ceramic glazes was called liu-li 琉璃 (in the Han Annals 流 離) or pii-liu-li, derived from Prākrit veluriya, Mahārāshțrī verulia (Sanskrit vaidūrya). ${ }^{4}$ The Wei lio,

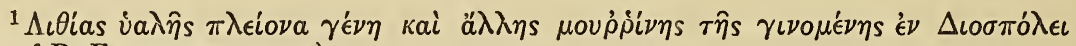
(ed. of B. FABRICIUS, p. 42).

${ }^{2}$ Compare T. ReIL, Beiträge zur Kenntnis des Gewerbes im hellenistischen Ägypten, pp. 37-50. The mass is well described by W. M. Flinders Petrie (Arts and Crafts of Ancient Egypt, p. II7): "Quartz rock pebbles were pounded into fine chips after many heatings which cracked them. These were mixed with lime and potash and some carbonate of copper. The mixture was roasted in pans, and the exact shade depended on the degree of roasting. This mass was half fused and became pasty; it was then kneaded and toasted gradually, sampling the color until the exact tint was reached. A porous mass of frit of uniform color results. This was then ground up in water, and made into a blue or green paint, which was either used with a flux to glaze objects in a furnace, or was used with gum or white of egg as a wet paint for frescoes."

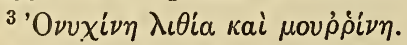

${ }^{4}$ Palladius (Chinese-Russian Dictionary, Vol. I, p. 367), our foremost authority on Chinese lexicography, has given as the principal meaning of liu-li "glaze" (Russian glazur). Several writers accept the term liu-li in the too narrow sense of "glass" only, and construe a theory that quantities of glass vessels were imported at the Han time from the workshops of Syria and Egypt (for instance, S. W. BusHeLL, 
written in the third century A.D., attributes to Ta Ts'in ten varieties of liu-li,- carnation, white, black, green, yellow, blue, purple, azure, red, and red-brown. ${ }^{1}$ This extensive color-scale shows th that not a precious stone is involved (and with reference to India $p^{\prime} i$-liu-li or liu-li may well denote a variety of quartz or rock-crystal ${ }^{2}$ ), but an artificial, man-made product. This is clearly evidenced by other texts, in which the peculiar utilization of $l i u-l i$ in $\mathrm{Ta} T \mathrm{~T}^{\text {in }}$ is specified. Thus we are informed by the Tsin Annals that the people of Ta Ts'in use liu-li in the making of walls, and rock-crystal in making the bases of pillars. The Kin T'ang shu reports that eaves, pillars, and windowbars of the palaces there are irequently made of rock-crystal and liu-li. ${ }^{3}$ Glazed faience for architectural purposes is doubtless alluded to in these two cases; and we face here the same combination of murra and crystal as we noticed in Pliny. ${ }^{4}$ It was almost at the same time, or only a little later, that the knowledge of glazed ware spread to the West and the Far East alike from the same focus. It thus was the knowledge of the highly-developed ceramic processes of the anterior Orient, at their climax in the second century B.c. or earlier, which was transmitted to China, and gave there the impetus to the production of glazes.

The conception of liu-li as a prccious stone is chiefly upheld in Buddhist texts; but in reading these with critical understanding it is obvious that something else is hidden behind this alleged stone. The $Y i$ ts'ie king yin $i,{ }^{5}$ written by Yüan Ying about A.D. 649 , states that

Chinese Art, Vol. II, p. I7). Nothing of the kind, however, is to be found in the ancient Chinese texts, which, with reference to the Roman Orient, never mention any vessels of $l i u$-li, but merely speak of a substance of that name, without any reference to objects made from it. This clearly indicates that no vessels of any sort were imported, but only pasty masses of various tinges which could be applied to pottery bodies. That liu-li has nothing to do with the production of glass, simply results from the fact that only as late as the fifth century A.D. did the Chinese learn from foreigners how to make glass. If glazed ware makes its appearance under the Han, it is obvious that it bears some relation to the liu-li originating from the Roman-Hellenistic Orient.

${ }^{1}$ Hirth, China and the Roman Orient, p. 73.

${ }^{2}$ See T'oung Pao, I915, p. 198. In the dictionary Kuang $y a$ of the third century (Ch. 9, p. 5 b; ed. of Han Wei ts'ung shu) liu-li is classed with quartz (shui tsing 水精).

${ }^{3}$ Hirth, $l$. c., pp. 44, 5I. Hirth translates liu-li by "opaque glass;" but such walls and pillars of glass have not yet been discovered.

${ }^{4}$ In Egypt, as early as 5500 B.c., glazing was applied on a large scale for the lining of rooms. Tiles have been found about a foot long, stoutly made, with dovetails on the back, and holes through them edgeways in order to tie them back to the wall with copper wire. They are glazed all over with hard blue-green glaze (W. M. Flinders Petrie, Arts and Crafts of Ancient Egypt, p. 108).

${ }^{5}$ Ch. 23, p. I2 b (see above, p. I15). This text has been adopted by the Fan yi ming $i$ tsi (Ch. 8, p. 12 b; edition of Nanking). 
"the name liu-li or $p^{\prime} i$-liu-li is derived from that of a mountain, and is said to be the precious stone of a distant mountain, which is the Sumeru of Buddhist cosmology. This jewel is of green (靑) color. Altogether, all jewels cannot be injured, nor can they be melted and cast by means of blaze and smoke. Only the demons and spirits have sufficient strength to break them to pieces. There is further a saying that liu-li is the shell of the egg of the bird with golden wings. ${ }^{1}$ The demons and spirits obtain it and sell it to mankind." This Chinese text is the reproduction of a theme of Indian lore; and the tradition hints at the importation into India of a substance from abroad, which could be wrought only by demons (that is, foreigners). ${ }^{2}$ The allusion to melting shows that it really could be melted; and the comparison with the shell of a bird's egg, which hints at a coating, is the best possible poetical metaphor for a ceramic glaze. It thus seems to me that the Sanskrit term vaidu urya and its congeners originally denoted some semi-precious quartz-like stone, and were then transferred to the enamel glaze of the anterior Orient. ${ }^{3}$

Chinese tradition refers the earliest employment of liu-li to the reign of the Emperor Wu (I40-86 B.C.) of the Former Han dynasty. It is said in the Annals of the Han that this sovereign despatched special agents over the sea for the purchase of the substance p ${ }^{\prime} i-l i u-l i{ }^{4}$ It was likewise known at that period that this article figured among the products of the country Ki-pin (Kashmir), which opened intercourse with China under the same emperor. ${ }^{5}$

It is notable that in the Han period objects were found under ground, said to have been made of liu-li, and that we have accounts of objects wrought from liu-li by Chinese craftsmen. Since glass was manufactured in China only several centuries later, it cannot come here into question; and from the nature of these objects it follows that they cannot either have been of rock-crystal or lapis lazuli. In the biography of $\mathrm{Hu}$ Tsung 胡 綜 $^{6}$ it is narrated that $\mathrm{Hu}$, during the life

1 The saliva of this bird was believed to produce the gem mu-nan (see this volume, p. 70, note 3 ). It is the fabulous bird Garuda.

${ }^{2}$ It is a well-known fact that foreign tribes were characterized by the Aryan Indians as demons under such names as Nãgas, Rākshasas, or Piçācas.

${ }^{3}$ It is possible also that the Indian words are derived from a West-Asiatic language.

${ }^{4}$ In the geographical chapter of the Ts'ien Han shu (Ch. 28 в, p. I7 b).

- Ts'ien Han shu, Ch. 96 A, p. 5. S. W. Bushell (Chinese Art, Vol. I, p. 6I) dates the appearance of glaze in China only from the Later Han dynasty (A.D. 25-220).

6 San kuo chi, Wu shu, Ch. 62. See also $Y u$ yang tsa tsu, Ch. II, p. 4 (ed. of Pai hai). 
time of Sun K'üan 孫權 (A.D. I $8 \mathrm{I}-25^{2}$ ), while digging the ground, found a copper or bronze chest two feet and seven inches long, the cover of it being made of liu-li (掘地得銅匣長二尺七寸以琉璃 䉆茼). This bronze vessel evidently was of Chinese make; and the only reasonable supposition is that the cover was of glazed ware, the whole affair coming down from the Former Han dynasty. Sun Liang 孫亮, who died in A.D. 260, a son of the aforementioned Sun K'üan, made a screen of $l i u-l i{ }^{1}$

In the Han wu ku shi 漢武故事 (that is, "Old Affairs relating to Wu of the Han Dynasty") it is on record that Wu was fond of the gods and genii, and erected in their honor sanctuaries the doors of which were coated with a white glaze (pai liu-li 白瑠璃) that reflected its light afar. The Emperor Ch'eng (32-7 B.c.) built the palace Fut'ang 服湯殿 for Chao Fei-yen, and had the doors glazed green. ${ }^{2}$ In the same manner, liu-li is combined with the names for pottery vessels: thus we read about "glazed wine-cups" (liu-li chung 琉璃鍾) ${ }^{3}$ and glazed bowls (liu-li wan 椀). ${ }^{4}$ The Chinese hardly ever made use of glass for practical household purposes. Pottery was always the article they preferred. Wine being taken hot, glass was prohibitive for wine-cups. The same holds good for tea. Glass beads were the only article of practical utility to the Chinese. Those who have written on glass in ancient China, merely by consulting Chinese sources, seem to have never seen antique glass or collections of Chinese glass. When the making of glass became known to the Chinese, they began to cut and polish it in its hard state; that is, they treated it in the same manner as hard stone, and applied to it the principles of their glyptic art. Glass became the domain of the carver, of a rather limited artindustrial importance, but it never had any practical bearing upon the

${ }^{1} K u$ kin chu 古今 注 (Ch. c, p. 5 b; ed. of Han Weits'ung shu). A fantastic description of this screen is given in the Shi $i$ ki 拾遺記 (Ch. 8, p. 6; ed. of Han Wei ts'ung shu). There are several other allusions to such screens of liu-li, which in my opinion were made of a thin wall of clay coated with a glaze.

${ }^{2} T^{*} a i$ p'ing yü lan, Ch. 808, p. 4. Several writers have conceived the windows and doors of this palace as being made of glass (for instance, A. Forke, Mitt. Sem. or. Spr., Vol. I, p. I I3); but we do not know that window-glass existed at the same time in the Western world. Scanty remains of window-glass have been found only in Pompeii and Herculaneum, but no extensive use was ever made of it in the time of the Roman empire. In western Asia no window-glass was made, and accordingly no export to China could take place. Aside from this point, I would be disinclined to believe in the possibility of transporting window-glass from the Orient to China at that time.

${ }^{3} T \sin \operatorname{sh} u$, Ch. 45 , p. 8.

${ }^{4} Y u ̈ a n$ kien lei han, Ch. 364, p. 3 I b; glazed dishes for eating in $T \sin \operatorname{shu~(T'ai~}$ piing yü lan, Ch. 808, p. 4 b). 
life of the people. Certainly, the term liu-li refers also to opaque glass, especially from the fifth century onward. If in 5I9, under the Emperor $\mathrm{Wu}$ of the Liang dynasty $\left(5^{\circ} 2-520\right)$, Khotan sent to China

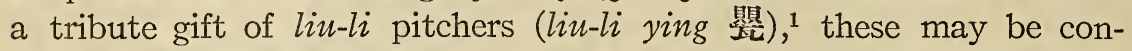
ceived of as glass as well as of glazed pottery. In other passages the exact significance of the term remains doubtful, as in the case of a saddle of brilliant white liu-li, which in the dark emitted light at the distance of a hundred feet, and which is mentioned in the Si king tsa ki 西京雜記 ${ }^{2}$ among presents sent to the Emperor Wu from India. Here we have a fabulous echo of traditions that were exaggerated by later generations.

It is a significant fact that the reign of the same Emperor $\mathrm{Wu}$ is characterized by the sudden rise of alchemy and chemical notions and experiments $;^{3}$ and this novel line of thought is certainly connected with the western expansion and the newly-opened trade-routes across Central Asia inaugurated by the same sovereign. In the Greek alchemical papyri we meet the oldest technical recipes for the fabrication of glass and enamels, and technical treatises on glass. ${ }^{4}$ Aeneas of Gaza, a Neo-Platonic philosopher of the fifth century, represents glass directly as an alchemical transmutation from a baser to a nobler material by observing, "There is nothing incredible about the metamorphosis of matter into a superior state. In this manner those versed in the art of matter take silver and tin, change their appearance, and transmute them into excellent gold. Glass is manufactured from divisible sand and dissoluble natron, and thus becomes a novel and brilliant thing." 5 We have a few intimations to the effect that liu-li was appreciated also by the Chinese alchemists. Tung-fang So obtained multi-colored dew and placed it in glazed vessels, which he offered as a gift to the Emperor Wu. ${ }^{6}$ The famous alchemist Li Shao-kün 李少君, whose life and deeds have been narrated by Se-ma Ts'ien, is said to have repaired the brilliant-white liu-li saddle of $\mathrm{Wu}$ mentioned afore, when this saddle was once broken during an imperial hunting-expedition; he availed himself of pieces of bone, which were joined by means of a thin, sticky substance, with such good effects, that no damage could be

${ }^{1}$ Liang shu, Ch. 54, p. 14 b.

${ }^{2}$ Ch. 2, p. 2 b (ed. of Han Wei ts'ung shu). p. 465 .

${ }^{3}$ See particularly Chavannes, Mémoires historiques de Se-ma Ts'ien, Vol. III,

${ }^{4}$ M. Berthelot, Introduction à l'étude de la chimie des anciens et du moyen âge, pp. 200, 202; Les Origines de 1'alchimie, pp. I23, I25.

${ }^{5}$ M. Berthelot, Origines, p. 75.

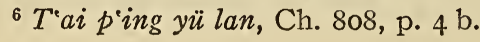


perceived even in broad daylight. ${ }^{1}$ When the ancient Chinese literature on alchemy shall have become as accessible as the Greek, Arabic, and European records of this ancient science, the subject in question will doubtless receive further elucidations.

While liu-li was imported into China from the Hellenistic Orient over the established trade-routes across Central Asia, and from Kashmir, another source of supply was represented by Cambodja, which, as we know, was in intimate commercial relations with India, and received from there the products and merchandise of western Asia. In the Calendar or Chronological Tables of the Country of Wu (Wu li 吳歷), by $\mathrm{Hu} \mathrm{Ch}^{\prime}$ ung 胡沖, ${ }^{2}$ it is on record that in the fourth year of the period Huang-wu 黄武 (A.D. 225), Fu-nan 扶南 (Cambodja) and other foreign countries sent envoys to China with gifts of liu-li. ${ }^{3}$ According to another version of the same text, this event would have taken place in the period Huang-lung 黃龍 $(229-23 \mathrm{I}) .^{4}$ This text contains the mention of the first embassy from Fu-nan (Cambodja) to China, and allows us to infer that liu-li was found there in the beginning of the third century and transmitted to China. Another allusion to the presence of liu-li in the countries south of China is encountered in the Kuang chi 廣志, written by Kuo I-kung 郭義恭 under the Liang dynasty $(502-556)$, where it is said that liu-li is a product of Huang-chi 黃支, ${ }^{5}$ Se-tiao 斯調, ${ }^{6} \mathrm{Ta}$ Ts in, and Ji-nan 日 南 (Annam). Finally liu-li was sent also to China from Central India under the Liang dynasty $\left(502-55^{6}\right){ }^{7}$

Our most important witnesses certainly are the numerous specimens of Han mortuary pottery glazed in the most varied shades of green

${ }^{1} T^{*} u$ shu tsi ch'eng, under liu-li.

2 Pelliot, Bull. de l'Ecole française, Vol. IV, p. 391.

3 Yüan kien lei han, Ch. 364, p. 3 I.

${ }^{4} T^{\text {'ai }}$ p'ing yü lan, Ch. 808, p. 4 b. Compare also Pellior, Le Fou-nan (Bull. de l'Ecole française, Vol. III, p. 283). The Wu dynasty, one of the Three Kingdoms ( $\operatorname{san} k u o$ ), reigned from 222 to 280 .

${ }^{5}$ Presumably on the Malay Peninsula (see Chinese Clay Figures, p. 8o, note 2). Liu-li is also enumerated among the tribute-gifts sent from Huang-chi to the Chinese Court ( $T^{\prime} a i$ p'ing huan yï ki, Ch. 176, p. 2 b). Pi-liu-li is mentioned as an article of Huang-chi as early as the Han period (Ts'ien Han shu, Ch. 28 B, p. I7).

${ }^{6}$ Probably Java ( $T^{\circ}$ oung Pao, I9I5, pp. 35I, 373). In the latter passage I mentioned a plant mo-ch' $u$ as growing in Se-tiao. M. G. Ferrand, Consul General of France in New Orleans, has been good enough to write me that this Chinese transcription corresponds to Javanese mojo, the designation of the tree Aegle marmelos, and that the emendation of Se-tiao into Ye-tiao is thus assured, and the identification of Ye-tiao with Java becomes a definite result. M. Ferrand himself will soon report about this ingenious discovery.

${ }^{7}$ Liang shu, Ch. 54 , p. 8. 
and brown, and still called by the Chinese liu-li wa 瑠璃瓦. ${ }^{1}$ The fact that the process of glazing itself is not described in the ancient texts, as pointed out by Hobson, is not of great concern. In fact, we have no ancient description of pottery whatsoever; and no technical treatise, if there ever was any, has survived from the Han period. The subject of pottery began to interest Chinese scholars only as late as the age of the Sung and Yüan; and in the same manner as the old writers fail to record the evolution of porcelanous ware, they are reticent as to glazing and other ceramic processes. It cannot be strongly enough emphasized that our knowledge of the subject should be reconstructed on the basis of actual material before our eyes, and not on literary sources which are still very incompletely exploited, or on philological considerations. It is unreasonable to expect also that literary traditions and antiquities of China should blend into a uniform and harmonious picture: neither is such the case in the archæology of Greece or Italy. We have hundreds and hundreds of Chinese antiquities which cannot be traced to any records, but it would be an absurd procedure to disregard them simply for this reason. Monuments speak their own language, and are entitled to a fair and impartial hearing on their own merits. Both monuments and literature have come down to us only in fragments; and while it is not necessary that one department confirms the other, we must regard ourselves fortunate in seeing one supplemented by the other. ${ }^{2}$

Owing to their lack of interest in technical matters, the notions of Chinese scholars regarding liu-li are the vaguest possible. Mong

${ }^{1}$ A disk labelled pi-liu-li is represented on the Han bas-reliefs among the objects of happy augury. No conclusions can be drawn from this design as to objects made from liu-li, as the artist took the first element $p i$ in the sense of "disk" or "ring," and based his conception on this interpretation. His work represents merely an art-motive, not a reality. This subject has been well expounded by E. Chavannes (Mission archéologique, Vol. I, La sculpture à l'époque des Han, p. 170$)$.

2 There are several allusions to green-glazed Han pottery in Chinese writings. One is extracted by Hobson (Chinese Pottery and Porcelain, Vol. I, p. I99) from the Gazetteer of Shen-si Province, and refers to the village Lei-siang in the prefecture of T'ung-chou, where the inhabitants sometimes dig up castaway wares, archaic in shape and style, of green, deep and dark, but brilliant color, some with ornaments in raised clay. The Gazetteer of the District of Hua-yang (forming with the district of Ch'eng-tu the prefectural city of Ch'eng-tu, the capital of Szech'uan) reports (Ch. 4I, p. 64), “An ancient pottery censer (古瓦香鼎) is in the Kuang-fa temple (廣法 寺), outside of the city, twenty $l i$ in easterly direction. It is rectangular in shape, posed on four feet, two feet five inches in length, and one foot two inches in width. It is provided with lion's ears [relief designs of animalheads], and is green and glossy. According to a tradition it is an object of the Shu Han period (22I-264)." 
K'ang of the third century, commenting on the Han Annals, ${ }^{1}$ remarks that $p^{\prime} i-l i u-l i$ is green in color, like jade. Yen Shi-ku (579-645), however, rejects this generalization, observing that Mong K'ang's definition is too narrow; that the substance is a natural object, variegated, glossy, and brilliant; that it exceeds any hard stones (玉); and that its color is unchangeable. "It is the present practice," he continues, "to prepare it by the use of molten stones, with the addition of certain chemicals to the flux. This mass, however, is hollow, brittle, and not evenly compact; it is not the genuine article." 2 This is apparently an allusion to glass. The notion that $p^{\prime} i$-liu-li was regarded as a product of natural origin was suggested by the meaning "quartz," which originally adhered to the Sanskrit term vaidurya, the prototype of the word pi-liu-li; but this does not mean that vitreous bodies were taken by the ancient Chinese for precious stones, as has been intimated by some authors. The confusion is one of terminology rather than of realities. The parallel with the conception of murra as a stone is obvious.

In the Nan chou $i$ wu chi 南州異物志, by Wan Chen 萬震 of the third century, we read as follows: ${ }^{3}$ "The principal material underlying liu-li is stone. In order to make vessels from it, it must be worked by means of carbonate of soda. ${ }^{4}$ The latter has the appearance of yellow ashes, which are found on the shores of the southern sea, and are suitable also for the washing of clothes. When applied, it does not require straining; but it is thrown into water, and becomes slippery like moss-covered stones. Without these ashes, the material cannot be dissolved." This is probably a recipe for making a glaze. Compare the Chinese notions on using ashes for porcelain glazes and obtaining such ashes. ${ }^{5}$

At the Court of the Mongol lynasty, four kilns were established in I 276 at Ta-tu for the manufacture of plain, white-glazed bricks and tiles (素白琉璃碍 看), with an army of three hundred workmen. The so-called Southern Kiln (nan yao 南窑) was erected in I 263 , the Western Kiln (si yao 西蕧) in I267, and that of Liu-li kü 琉㑾局 (northwest of Peking) in I $263 .^{6}$ The latter was still operated under the

1 Tsien Han shu, Ch. 96 A, p. 5.

${ }^{2}$ Hobson (Chinese Pottery and Porcelain, p. 144) gives only an abridged quotation of Yen Shi-ku's text, as quoted in the T'ao shuo, which does not bring out the author's true meaning. The main point is that Yen Shi-ku regarded pi-liu-li as a natural substance, and looked upon the artifacts of his time as poor substitutes.

${ }^{3} T^{\circ} a i$ p’ing yü lan, Ch. 808, p. 5 .

"Tse jan hui 自然灰, literally "natural ashes;" used also with reference to a kind of earth and feldspath (GEerts, Produits, pp. 404, 416).

${ }^{5}$ Julien, Histoire et fabrication de la porcelaine chinoise, p. I3 1 .

- Yüan shi, Ch. 9o, p. 5. 
Manchu dynasty, furnishing the well-known glazed tiles and bricks for the palace, official buildings, and state temples of the metropolis. Glazed tiles and bricks, however, were known in China long before the time of the Yüan. They certainly existed under the Sung. Chou Shan, who in A.D. II77 accompanied an embassy sent by the Sung Emperor from Hang-chou to the Court of the Kin dynasty at Peking, reports that the palace of the Kin was covered with tiles, all coated with enamels, their colors resplendent in the sunlight. ${ }^{1}$ Ngou-yang Siu (I007-72) speaks of glazed tiles. ${ }^{2}$ Sir AUREL STEIN ${ }^{3}$ discovered in the ruins of Ch iao-tse bricks and tiles bearing in beautiful green glaze scroll ornaments in low reliefs, and employed in a Stūpa constructed during Sung times. ${ }^{4}$ Glazed tiles were likewise known under the T'ang. A certain Ts'ui Yung 崔融, who lived in the T'ang era, erected on Mount Sung in Ho-nan, in honor of his mother, a memorial temple covered with glazed tiles (liu-li chi wa). The famous poet Po Kü-i (A.D. $77^{2-846)}$ speaks of a pair of white-glazed (pai liu-li) vases. ${ }^{5}$ Remains from buildings of this period show also the application of glazing for architectural purposes. The bricks and tiles of the Han and Wei periods, as far as we know them, are all unglazed, but it would be premature to assert that glazing was then not applied to them. ${ }^{6}$

The continuity of Chinese tradition is vividly illustrated by the fact that the term liu-li, in the same manner as in the Han period, denotes glazed pottery also at the present time. From the T'ang period onward, when porcelain came into vogue as a special class of ceramic ware, a division of nomenclature took place,- liu-li remaining reserved for common pottery, tiles, bricks, and other buildingmaterial, while a new term was adopted for a porcelain glaze. The porcelain enamel was styled $y u$ 油 ("oil"), written also 砘, 嬏, ${ }^{7}$ and 泑. As far as I know, this term is first applied by Liu Sün of the T'ang

1 Chavannes, Pei Yuan Lou ( $T^{\circ}$ oung Pao, 1904, p. 189). Green-glazed tiles were employed in the palace of the Sung Emperors, according to the Yü t'ang kia huo written by Wang Hui in 1360 (Ch. 4, p. 4 b; ed. of Shou Shan ko ts ung shu).

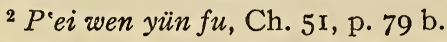

${ }^{3}$ Ruins of Desert Cathay, Vol. II, p. $25^{2}$.

${ }^{4}$ Many remains of fine glazed pottery were found by Stein on his third expedition in the ruins of Karakhoto (A Third Journey of Exploration in Central Asia, p. 39, reprint from Geographical Journal for August and September, 1916). See also the same author's Ancient Khotan, Vol. I, pp. 442, 482.

${ }^{5} T^{*} u$ shu tsi ch'eng, xxvII, Ch. 334 .

${ }^{6}$ For further notes on this subject see Hobson, Chinese Pottery and Porcelain, Vol. I, pp. 20 I et seq.

${ }^{7}$ According to K'ang-hi's Dictionary, this character is first listed in the $T s i$ yün (middle of the eleventh century). 
period, in his Ling piao $l u i{ }^{1}$ where the making of earthen cookingkettles in the potteries of Kuang-tung is mentioned: "They were fired from clay and then glazed" (燒熱以土油之). A gloss explains $y u$ as 粙. What is meant here is the application of porcelain glazes to earthenware. In ceramic literature the term $y u$ refers exclusively to porcelain enamels. ${ }^{2}$ It is quite certain also that in the present colloquial language glass is exclusively styled $p^{\circ} o-l i$, never liu-li, which strictly refers to glazed ware.

While we recognize that the Chinese received the stimulus for the production of ceramic glazes from western Asia, it must be emphasized at once that it was no more than a stimulus, and that the Chinese were not slavish imitators, but soon applied their own genius to the novel idea. The green glaze of the Han pottery, as analyzed by $\mathrm{Mr}$. Nichols (p. 93), may have its analogies in the West, and a thorough search for corresponding materials would in all probability bring to light a Western recipe of the same composition. The first step to independence, however, is taken by the production of the porcelanous glaze of post-Han times (p. 9o), which hardly offers any contemporaneous parallel in the West. From this time onward the Chinese have exercised their own acumen in perfecting the process of glazing and multiplying the scale of beautiful colors. Flinders Petrie ${ }^{3}$ has offered the ingenious suggestion that glaze in prehistoric Egypt, where it is found on quartz bases, was probably invented from finding quartz pebbles fluxed by wood ashes in a hot fire; hence glazing on quartz was the starting-point, and glazing on artificial wares was a later stage. Such observations of natural glazes may have also impressed and stimulated the Chinese. The Field Museum owns two earthenware crucibles, obtained by the writer in Si-ngan fu (Cat. Nos. IIg076 and II9077), which by purely natural causes, owing to the infusion of molten metals, are colored a sky-blue with red flecks; likewise a meltingpot (Cat. No. I I9347), artificially glazed in the interior and in the upper portion of the exterior, while the lower unglazed part has assumed natural colors of fiery-red and dark green from the effect of liquid metals. It is not impossible that this natural process of glazing inspired the imagination of the potters and gave the incentive for certain mottled ceramic glazes.

${ }^{1}$ Ch. A, p. 6 (ed. of $W u$ ying tien).

${ }^{2}$ Julien, Histoire et fabrication de la porcelaine chinoise, pp. 245, 247.

${ }^{3}$ Arts and Crafts of Ancient Egypt, p. 107. 


\section{THE POTTER'S WHEEL}

When the clay is on the wheel the potter may shape it as he will, though the clay rejoins, "Now you trample on me, one day I shall trample on you.'

Sir Herbert Risley, The People of India.

Most of the phenomena of Chinese culture have hitherto been studied in splendid isolation. Sinologues have usually been content to gather their information from Chinese sources and to arrange it in chronological order, giving a more or less critical digest of the subject from the Chinese viewpoint; but the question as to what the phenomena actually mean is, as a rule, shunned, their interpretation hardly attempted. It is certainly impossible to grasp any phenomenon within a given culture-zone without understanding the parallel phenomena in other areas, and without setting them in correlation with their concomitant factors. The historical position and development of any cultural idea can be determined only by an attempt to unravel its causal connection with the natural group of related or associated ideas; for no phenomenon is isolated or absolute, but conditional upon others, relative, and cohesive. Whether this method be styled that of comparative ethnology or archæology, or that of culture-science, or something else, does not matter. It is there, and must be applied if we are eager to reach results. How it can be applied I wish to demonstrate by discussing on the following pages the nature of a simple instrument, - the potter's wheel. Its concatenation with other technical elements and with social and religious factors will be pointed out, and may help to show the history of pottery in a new light, and in particular to determine the relation of ancient Chinese ceramic art to that of the West. In a case like this one, the foundation of which reaches back into a prehistoric past, a purely historical method is of no avail, and will lead us nowhere. Thus HoBson ${ }^{1}$ observes, "Unfortunately, none of the [Chinese] writers can throw any light on the first use of the potter's wheel in China. It is true, that, like several other nations, the Chinese claim for themselves the invention of that essential implement, but there is no real evidence to illuminate the question, and even if the wheel was independently discovered in China, the priority

${ }^{1}$ Chinese Pottery and Porcelain, Vol. I, p. 2. 
of invention undoubtedly rests with the Near Eastern nations." This indeed is all that from an historical point of view could be stated.

The making of pottery may well be called a universal phenomenon, despite the fact that there are many areas inhabited by peoples not acquainted with the art. It is unknown to the natives of Australia, New Zealand, and all other island groups of the South Sea populated by Polynesians ${ }^{1}$ (while it thrives among the Melanesians), to the Negrito of the Philippines, to numerous primitive tribes of the IndoChinese, ${ }^{2}$ to the inhabitants of the Himalaya (with the exception of the Nepalese), and to many nomadic and hunting tribes of Siberia. ${ }^{3}$ It is further absent in the extreme southern parts of South Africa and South America, also in the whole north-western portion of North America. Among the polar peoples, pottery has hardly any importance. Of the Eskimo, only the western group in Alaska makes (or

1 With the exception of Easter Island, where pottery is used for the cooking of certain foods (A. Lesson, Les Polynésiens, Vol. I, p. 457; Vol. II, p. 282). It is difficult to accept the oft-repeated statement that the Polynesians do not make pottery for want of proper clays in their habitats. There surely is workable clay in New Zealand and Hawaii; but whether there is or not, I believe with E. B. TyLOR (Primitive Culture, Vol. I, p. 57), that, "as the isolated possession of an art goes to prove its invention where it is found, so the absence of an art goes to prove that it was never present: the onus probandi is on the other side."

2 Thus the Lo-lo have never produced pottery (A. F. LEgendre, Far West chinois, T'oung Pao, 1909, p. 611).

${ }^{3}$ It is particularly lacking among the present-day tribes of the Amur, also among the Gilyak and Ainu. Hü $K^{\prime}$ ang-tsung, who as Chinese ambassador in I 25 visited the Kin or Djurchi, observed that the latter made no vessels of clay, but only wooden cups and plates coated with a varnish (CHAvannes, Voyageurs chinois, Journal asiatique, 1898, mai-juin, p. 395). The same observation still holds good for all Amur tribes, which during historical times appear never to have manufactured pottery. The Japanese traveller Mamiya Rinsס, who visited the island of Saghalin in 1808 , reports that the forms of the clay vessels and porcelains of the Gilyak (Smerenkur) resemble Chinese and Japanese ware (P. F. v. Siebold, Nippon, 2d ed., Vol. II, p. 233). The question is here of imported Chinese articles, and the observation is of no great consequence. Nevertheless L. V. ScHRENCK (Reisen und Forschungen im Amur-Lande, Vol. III, p. 448) has based an elaborate speculation on this passage, ascribing the manufacture of crockery and porcelain (!) to the Olcha and Gold on the Amur in the first part of the nineteenth century, and making the Manchu-Chinese Government responsible for the forcible destruction of this industry. This is a fantasy of the worst kind, for which no foundation exists in the history of the Amur tribes. What the Chinese colonists manufactured in Manchuria was only crude pottery; contrary to what is asserted by L. v. Schrenck, porcelain was never made there. The term "porcelain" used in Siebold's translation of Mamiya Rinsō's account with reference to a kiln in the village Kitsi, on the right bank of the Amur, as usual in such cases, rests on a mistranslation. It is of greater importance that the Japanese traveller tells us of earthen pots six to seven inches in diameter, with loop handles on both sides, made at his time by the Ainu of Saghalin. There is indeed reason to believe that the Ainu formerly made a rude and primitive kind of pottery. From the lips of an Ainu seventy years old, on the 
rather made) lamps of clay, which ordinarily are turned out of soapstone, and cooking-pots. ${ }^{1}$

A. ByHAN ${ }^{2}$ is disposed to assume that pottery is of foreign origin among the Eskimo. The Chukchi, according to Bogoras, ${ }^{3}$ have now forgotten this industry, but it never was more than a sporadic phenomenon among them. The Itelmen of Kamtchatka formerly manufactured clay vessels, chiefly lamps, as shown by finds in ancient pitdwellings. ${ }^{4} \mathrm{~F}$. BoAs ${ }^{5}$ is inclined to attribute the presence or absence of pottery to geographical location rather than to general cultural causes. Economic conditions have a certain bearing on the question. The production of clay vessels is dependent upon a sedentary mode of life. Pastoral tribes, as a rule, evince no inclination toward the industry, and deem utensils of bark, wood, or metal preferable. In Tibet, with its twofold population of agricultural and nomadic elements, we find the use of pottery only among the stationary settlers, never among the roaming shepherds. Even among the former it is an art introduced from China, as is evidenced by the few kilns in eastern Tibet which are operated by Chinese potters. ${ }^{6}$

The utilization of the potter's wheel is restricted to a well-defined geographical area. It occurs only in the Old World, and belongs to ancient Egypt, the Mediterranean and West-Asiatic civilizations, Iran, India, and China with her dependencies. It is germane to the higher stages of culture only, and is conspicuously lacking among all primitive tribes. In aboriginal American pottery the wheel was never employed.

northern Kuriles, ToRI has recorded the story of how pots were previously made there, chiefly by women (Mitteil. d. Ges. Ostasiens, Vol. IX, 1903, p. 327). As is well known, the Ainu of Yezo have preserved no recollection of pottery-manufacture (J. BAtchelor, The Ainu of Japan, p. 3IO), and also on Saghalin and the Kuriles the industry is now wiped out of existence. The prehistoric pottery found in the shell-heaps of Japan likewise must be attributed to the Ainu, who are thus to be classed among pottery-making peoples. See also p. I66, note 2.

${ }^{1}$ J. Murdoch, Ethnological Results of the Point Barrow Expedition (Ninth Report Bureau of Ethnology, I892, pp. 9I-93).

2 Polarvölker, p. 69.

${ }^{3}$ Mem. Am. Mus. Nat. Hist., Vol. XI, p. 186.

${ }^{4} \mathrm{~K}$. von Ditmar, Reisen und Aufenthalt in Kamtschatka, pp. 246-247. As early as I695, the first visitor to Kamtchatka, the Cossack W. Atlasov, reported that the inhabitants made wooden and earthen vessels (P. J. von STrAHLENBERG, Nord- und Östliche Theil von Europa und Asia, p. 435).

5 The Mind of Primitive Man, p. I83.

6 W. W. RockHILL, in a note to his edition of Sarat Chandra Das' Journey to Lhasa (p. 88), states that, though he never saw the making of pottery in Tibet, he knows that no wheel is used; which is perfectly correct, inasmuch as it is never handled by Tibetans. F. Grenard (Le Tibet, p. 286) observes, "Pottery is of indigenous manufacture, but the Chinese wheel is utilized." 
Our foremost authority on this subject, W. H. Holmes, ${ }^{1}$ makes this observation: "It is now well established that the wheel or lathe was unknown in America, and no substitute for it capable of assisting materially in throwing the form or giving symmetry to the outline by purely mechanical means had been devised. The hand is the true prototype of the wheel as well as of other shaping tools, but the earliest artificial revolving device probably consisted of a shallow basket or bit of gourd in which the clay vessel was commenced and by means of which it was turned back and forth with one hand as the building went on with the other." Of course, if further on (p. 69) Holmes styles the basket used as a support in modelling a clay vessel "an incipient form of the wheel," this is only a figure of speech, for this device bears no relation whatever to the wheel. This remark holds good also for "that simple approximation to a potter's wheel, consisting of a stick grasped in the hand by the middle and turned round inside a wall of clay formed by the other hand," evolved for North America by Squier and Davis, ${ }^{2}$ and the "natural primitive potter's wheel," consisting of a roundish pebble, ascribed to the New-Caledonians by O. T. MAson ${ }^{3}$ after J. J. Atkinson. Wherever wheel-turned pottery has been found in America on aboriginal sites, it has conclusively been proved either that it is of European manufacture, or that the wheel was introduced there by the white man. Thus it has been disclosed that the wheel-made jars, showing also traces of a brownish glaze, which were reported from Florida and other Southern States, and occasionally were even recovered from Indian mounds, are of Spanish manufacture, having been used in early Colonial times for the shipping of olives to America. ${ }^{4}$ The Quichua employ for the making of pottery a very simple lathe, which is justly traced to European influence by E. NoRdenskiöLd. ${ }^{5}$ It is worthy of note also that the distribution of the wheel over the area mentioned has remained almost stationary for millenniums, and that primitive tribes are not susceptible to adopting it, even if surrounded by civilized peoples who make use of it. The Vedda of Ceylon, for instance, fashion pots by hand, ${ }^{6}$ while the surrounding Singalese avail themselves of the wheel. Nothing of the

${ }^{1}$ Aboriginal Pottery of the Eastern United States, p. 50 (Twentieth Ann. Rep. Bureau Am. Ethnology, Washington, I903).

2 See J. Lubbock, Prehistoric Times (5th ed.), p. 260.

3 Origins of Invention, p. 16r.

4 Holmes, l. c., pp. 129-130.

${ }^{5}$ Einige Beiträge zur Kenntnis der südamerikanischen Tongefässe und ihrer Herstellung (Stockholm, 1906).

${ }^{6}$ C. G. Seligmann, The Veddas, p. 324 . 
character of a potter's wheel is known among the inhabitants of the Andaman group. ${ }^{1}$ Or, to cite another example, the Negroes of Africa have always remained unacquainted with the wheel, though they might have learned its use from the ancient Egyptians, or at a later time from the Arabs. The sporadic occurrence of the wheel in the Malayan Archipelago indicates its introduction from outside. It is found only in Padang Lawas on Sumatra and on Java; ${ }^{2}$ while in all other Malayan regions, including the Philippines, pottery has remained in the stage of handwork, and is the lot of woman. The Yakut, the most intelligent and progressive people of Siberia, never avail themselves of the potter's wheel, nor do they know of any process of glazing vessels. Despite the fact that they intermarry with the Russians, and that on the market of Yakutsk wheel-made Russian crockery is offered for sale, they still adhere to their primitive mode of fashioning vessels solely by hand, the only implement that is used being a half-round or round smooth stone, with which the interior of the pot is shaped and smoothed. Instead of securing Russian ware, they prefer to purchase the raw clay material (at from five to ten kopeck a pound), and entrust it to a skilful woman potter, together with fragments of old broken pots, which are pounded and mixed with the fresh clay. According to SÄroshevski, ${ }^{3}$ to whom we owe a detailed description of the process, also the illustration of a Yakut potter at work, these products come very near to those of the stone age. In their crude technique, they form a curious contrast to the excellent iron-forged work and wood-carving for which the same people are reputed.

While ethnologists have clearly recognized that the pottery-making of primitive peoples is essentially a woman's avocation, it has not yet been sufficiently emphasized that the wheel is a man-made invention, and that, aside from the mere technical difference of the hand and wheel processes, there is a fundamental sociological contrast between the two. Among the Indian tribes of America, the fictile art was woman's occupation, and such it is at present. In discussing the methods of primitive pottery, O. T. MAson ${ }^{4}$ observes, "It will be noted that the feminine gender is used throughout in speaking of aboriginal potters. This is because every piece of such ware is the work of woman's hands. She quarried the clay, and, like a patient beast of burden, bore it home on her back. She washed it and kneaded it, and rolled

${ }^{1}$ E. H. MAN, On the Aboriginal Inhabitants of the Andaman Islands, p. I54.

${ }^{2}$ Encyclopædie van Nederlandsch-Indië, Vol. III, pp. 32I, 322.

3 The Yakut (in Russian), Vol. I, p. 378.

${ }^{4}$ Origins of Invention, p. I66; see also his Woman's Share in Primitive Culture, p. 9I. 
it into fillets. These she wound carefully and symmetrically until the vessel was built up. She further decorated and burned it, and wore it out in household drudgery. The art at first was woman's." As regards Africa, we owe a very able investigation to H. ScHURTz, ${ }^{1}$ whose studies of African conditions prompted him to the conclusion that pottery everywhere appears to be an invention of woman, who was more urgently in need of boiling water in the preparation of vegetable food than man in dressing his hunting-spoils. A map constructed by Schurtz, and illustrating the distribution of pottery over Africa, shows at a glance that the largest territory is occupied by female potters; that male potters occur only in Abyssinia, among the Galla and Somali in eastern Africa, and this owing to Arabic influence. In a few other areas men are engaged in the making of the bowls for their cherished tobacco-pipes, while the women produce from clay all domestic and kitchen utensils; and in a few localities only, men and women co-operate in the ceramic industry. In regard to the Khasi in Assam, Major GuRDon ${ }^{2}$ observes, "The women fashion the pots by hand, they do not use the potter's wheel." On the Nicobars the men take no part in the construction of pots. ${ }^{3}$ All over Melanesia, pottery is made exclusively by women. The making of clay vessels is no longer practised by the Chukchi, but their old women (not the men) have a vivid recollection of the clay kettles which were used in former times. ${ }^{4}$

The potter's wheel, however, is the creation of man, and therefore is an independent act of invention which was not evolved from any contrivance utilized during the period of hand-made ceramic ware. The two processes have grown out of two radically distinct spheres of human activity. The wheel, so to speak, came from another world. It had no point of contact with any tool that existed in the old industry, but was brought in from an outside quarter as a novel affair, when

${ }^{1}$ Das afrikanische Gewerbe, pp. I3-19.

2 The Khasis, p. 6r.

${ }^{3}$ C. B. KLoss, In the Andamans and Nicobars, p. 107. According to E. H. MAN (On the Aboriginal Inhabitants of the Andaman Islands, p. 154), the manufacture of pots on the Andamans is not confined to any particular class, or to either sex, but the better specimens are generally produced by men. Compare the same author's Nicobar Pottery (J. Anthr. Institute, Vol. XXIII, I894, pp. 21-27). Also among the Vedda pots are turned out by both men and women (C. G. SELIGManN, The Veddas, p. 324).

"W. Bogoras, in Mem. Am. Mus. Nat. Hist., Vol. XI, p. I86. The industry of primitive pottery is fast dying out everywhere under the influence of "civilization" (compare, for instance, M. R. Harrington, Catawba Potters and Their Work, in Am. Anthr., Vol. X, I908, pp. 399-407; and The Last of the Iroquois Potters, in N. Y. State Mus. Bull., I909, pp. 222-227; as to Africa, see O. Baumann, Globus, Vol. LXXX, I901, p. I27). 
man appropriated to himself the work hitherto cultivated by woman. The development was one from outside, not from within. All efforts, accordingly, which view the subject solely from the technological angle, and try to derive the wheel from previous devices of the female potter, are futile and misleading. ${ }^{1}$ It is as erroneous as tracing the plough back to the hoe or digging-stick, whereas in fact the two are in no historical interrelation, and belong to fundamentally different culture strata and periods, - the hoe to the gardening activity of woman, the plough to the agricultural activity of man. Both in India and China, the division of ceramic labor sets apart the thrower or wheel-potter, and distinctly separates him from the moulder. The potters of India, who work on the wheel, do not intermarry with those who use a mould or make images. ${ }^{2}$ They form a caste by themselves. $^{3}$ In ancient China, a net discrimination was made between wheel-potters ( $t^{\circ} a$ o jen 陶 人) and moulders (fang ien 旊 人). ${ }^{4}$ This clear distinction is accentuated also by Chu Yen 朱琰 in his Treatise

${ }^{1}$ E. J. Banks (Terra-Cotta Vases from Bismya, Am. Journ. Sem. Langs., Vol. XXII, I905-06, p. 140) has this observation on the making of Babylonian pottery: "From the study of Bismya pottery it is evident that a wheel was employed at every period, yet all of the vases were not turned. No. 43, a form reconstructed from several fragments from the lowest strata of the temple hill, and which therefore dates several millenniums before 4500 B.C., has the appearance of having been formed by placing the clay upon a flat surface, and while the potter shaped it with one hand, he turned the board or flat stone, whatever it was upon which it rested, with the other. This was probably the origin of the potter's wheel; it was but a matter of time when an arrangement was attached to the board that it might be turned with the feet." All this is purely speculative and fantastic, and has no value for the real history of the wheel.

${ }^{2}$ A. BaInes, Ethnography (Castes and Tribes) of India, p. 65.

3 The social position of the Indian potter is differently described by various authors. H. Compton (Indian Life in Town and Country, p. 65) observes that the potter in India is an artist; that he is an hereditary village officer, and receives certain very comfortable fees; that his position is respected; that he enjoys the privilege of beating the drum at merry-makings, that he shares with the barber a useful and lucrative place in the community; and that there is probably no member of it who is happier in his lot, and less liable to the vicissitudes of fortune. H. RISLEy (People of India, p. I30) gives us a bit of Indian popular thought regarding the potter: "He lives penuriously, and his own domestic crockery consists of broken pots. He is a stupid fellow - in a deserted village even a potter is a scribe and his wife is a meddlesome fool, who is depicted as burning herself, like a Hindu wife, on the carcase of the Dhobi's donkey." According to G. C. M. Birdwood (Industrial Arts of India, Vol. II, p. I46), the potter is one of the most useful and respected members of the community, and in the happy religious organization of Hindu village life there is no man happier than the hereditary potter. The truth probably lies in the midway between these two extreme appreciations. As to ancient times, compare the Buddhist story of the sage potter, translated by E. LANG (Journal așiatique, 1912, mai-juin, p. 530).

${ }^{4}$ E. Biot, Tcheou-li, Vol. II, pp. 537-539. 
on Pottery. ${ }^{1}$ He justly observes also that the articles made by the wheel-potters were all intended for cooking, with the exception of the vessel yü 庂, which was designed for measuring; while the output of the moulders, who made the ceremonial vessels kuei 彾 and tou 豆 by availing themselves of the plumb-line, was intended for sacrificial use. Also here, in like manner as in ancient Rome, India, and Japan, the idea may have prevailed that a wheel-made jar is of a less sacred character than one made by hand.

Wherever the potter's wheel is in use, it is manipulated by man, never by woman. ${ }^{2}$ It is man's invention, it is man's sphere of work. As implied by its very name, it is directly derived from a chariot-wheel, which is likewise due to man's efforts. Such a real cart-wheel with four spokes is still operated by the Tamil potters. It is well illustrated by E. Thurston, ${ }^{3}$ and thus described after E. Holder (Fig. I): "The potter's implements are few, and his mode of working is very simple. The wheel, a clumsily constructed and defective apparatus, is composed of several thin pliable pieces of wood or bamboo, bent and tied together in the form of a wheel about three feet and a half in diameter. This is covered over thickly with clay mixed with goat's hair or any fibrous substance. The four spokes and the centre on which the vessel rests are of wood. The pivot is of hard wood or steel. The support for the wheel consists of a rounded mass of clay and goat's hair in which is embedded a piece of hard wood or stone, with one or two slight depressions for the axle or pivot to move in. The wheel is set into motion first by the hand, and then spun rapidly by the aid of a long piece of bamboo, one end of which fits into a slight depression in the wheel. The defects in the apparatus are, firstly, its size, which requires the potter to stoop over it in an uneasy attitude; secondly, the irregularity of its speed, with a tendency to come to a standstill, and to wave or wobble in its motion; and, thirdly, the time and labor expended in spinning the wheel afresh every time its speed begins to

${ }^{1} T^{`}$ ao shuo 陶 說, Ch. 2, p. 2 (new edition, I912). Compare S. W. Bushell, Description of Chinese Pottery, p. 33.

${ }^{2}$ Woman working on the potter's wheel is a strictly modern artificial reform of our "civilization," which tends to check the "man-made world," with the result that it insures woman's industrial enslavement to perfection. Mary WHite (How to make Pottery, p. 28) observes, "Until lately, few women potters have worked on the wheel, because the ordinary form of potter's wheel, which was turned with one foot, the potter standing on the other, made the work too difficult and laborious for a woman to attempt. Now, however, a wheel copied from an old French model is in use, which enables the potter to sit while at work."

${ }^{3}$ Castes and Tribes of Southern India, Vol. IV, p. I90. Holder's article is in Journal of Indian Art, No. 58, being accompanied by excellent illustrations of potter's wheels and of potters working at the wheel. 
slacken. Notwithstanding, however, the rudeness of this machine, the potters are expert at throwing, and some of their small wares are thin and delicate." It should be added, that, as may be seen in the illustration (Fig. I), the wheel is but slightly above the ground, and that the potter stands bent over the vessel. The apparatus, described by E. A. GaIT ${ }^{1}$ for the kilns of Assam, has likewise features in common with the cart-wheel. While the centre consists of a solid disk of tamarind or some other hard wood, about thirteen inches in diameter, there is an outer rim joined to it by means of four wooden spokes, each of these being about six inches in length. The outer rim, about six inches wide, is made of split bamboo, bound with cane, and covered with a thick plaster of clay mixed with fibres of the sago palm. The object of this rim is to increase the weight of the wheel, and thereby add to its momentum. ${ }^{2}$ In Assamese as well as in Bengāli, the potter's wheel is simply called cak ("wheel," from Sanskrit cakra).

In the Catapatha Brāhmana (XI, 8) the potter's wheel (kaulālacakra; kuläla, "potter;" cakra, "wheel") is thus alluded to in close connection with the cart-wheel: "Verily, even as this cart-wheel, or a potter's wheel, would creak if not steadied, so, indeed, were these worlds unfirm and unsteadied." 3 A similar association of ideas occurs in the Chinese philosopher Huai-nan-tse, who died in $\mathrm{r} 22$ в.c. $\mathrm{He}$ compares the activity of Heaven as the creative power with the revolutions of a wheel by saying, "The wheel of the potter revolves, the wheel of the chariot turns; when their circle is completed, they repeat their revolution." In the porcelain-factories of King-te-chen, the potter's wheel is styled t'ao ch'ê 陶車 (that is, "potter's chariot") or lun ch'ê 輪車 (that is, "wheeled chariot"). Ordinarily the potter speaks simply of his "wheel” (lun-tse 翰子). An engraving of about I540 shows an Italian potter's table in the shape of a regular sixspoked wheel. ${ }^{5}$ Technically speaking, the potter's wheel is nothing

${ }_{1}^{1}$ The Manufacture of Pottery in Assam (Journal of Indian Art,Vol.VII, 1897, p. 6).

${ }^{2}$ The Assam potters do not finish their pieces on the wheel, but when taken down and sun-dried, they are placed in a hollow mould of wood or earthenware, in which they assume their final shape by being beaten with a flat wooden or earthenware mallet, held in the right hand, against a smooth, oval-shaped stone held by the left hand against the inner surface. When the required shape has been given the vessel, it is again sun-dried, the surface being then polished with an earthenware pestle or a rag.

${ }^{3} \mathrm{~J}$. EgGeling's translation in Sacred Books of the East, Vol. XLIV, p. I26. The exact date of this work is not known, but it is believed that it goes back to the sixth century B.C.

${ }^{4}$ Chavannes, Mémoires historiques de Se-ma Ts'ien, Vol. V, p. 27.

Encyclopædia Britannica, Vol. V, p. 706. 


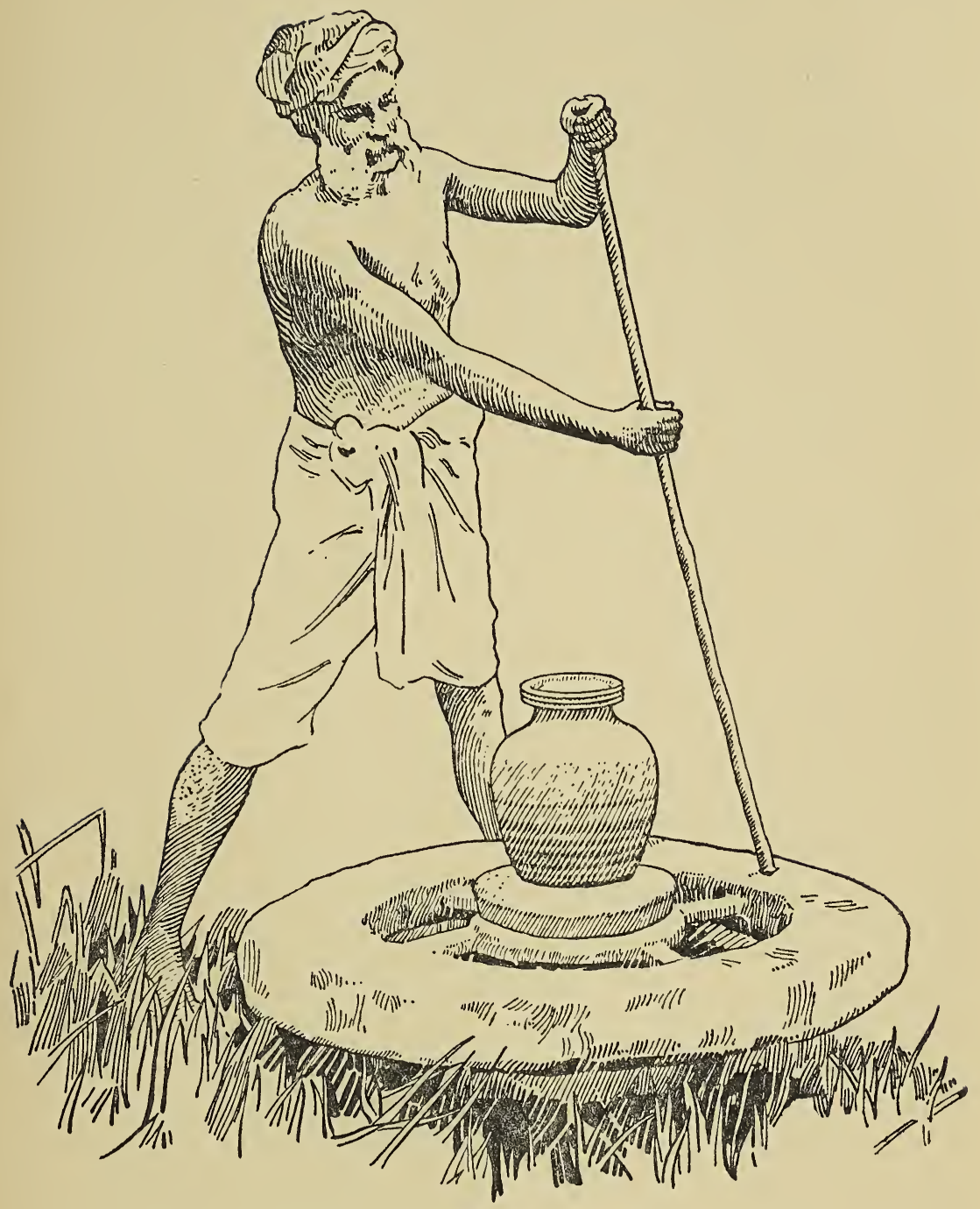

Fig. I

INDIAN POTTER'S WHEEL IN THE SHAPE OF A CART-WHEEL

(Sketch after Holder, Journal of Indian Art) 
but a primitive cart-wheel turning on its axle. The invention presupposes the existence of the wheel adapted to transportation, and in all the great civilizations in which, as stated above, the potter's wheel is found, we indeed meet also the wheeled cart. We further observe, that, wherever the potter's wheel occurs and the wheeled cart does not occur, the former was introduced from a higher culturezone: for instance, in Japan, to which the conception of the cart is foreign, and which received the potter's wheel from Korea; or among the Tibetans, who have no wheeled vehicles, and in the midst of whom the potter's wheel is only handled by Chinese. ${ }^{1}$ Again, the wheeled cart is conspicuously absent in all those culture-areas in which, as has been stated, the potter's wheel is unknown. Wherever original conditions have remained intact and undisturbed by outside currents, the two implements either co-exist, or do not exist at all. Of course, it must not be understood that the idea of the potter's wheel was conceived in a haphazard manner, as though a wheel, intentionally or incidentally, had been detached from a cart, its novel utilization being reasoned out on speculative and technical grounds. Primitive man, and man of the prehistoric past, is not a rationalistic or utilitarian being, but one endowed with thoughts of highly emotional character, and prompted to peculiar associations of ideas that are inspired by religious sentiments. Of the theories which have been expounded in regard to the primeval origin of the wheel, none as yet is wholly satisfactory; but this much is assured, that it was connected with a certain form of religious worship, that in its origin the chariot was utilized in the cult before it was turned to practical purposes of transportation. ${ }^{2}$ The symbolism and worship of the wheel in western Asia, prehistoric Europe and India, is so well known that this matter does not require recapitulation. A similar spirit pervades the early references to the potter, his work and his wheel. In the Old Testament the potter's control over the clay illustrates the sovereignty of God, who made man of clay, and formed him according to his will. "O house of Israel, cannot I do with you as this potter? saith the Lord. Behold, as the clay is in the potter's hand, so are ye in my hand, saith the Lord" (JerEmiar XVIII. I-6). "Shall the thing formed say to him that formed it, Why hast thou made me thus? Hath not the potter power

1 The wheeled cart is designated in Tibetan shing rta ("wooden horse"),- a word-formation which testifies to the fact that the cart is foreign to Tibetan culture. In fact, carts are not employed by Tibetans. We only read in ancient records of vehicles for the use of kings, presumably introduced from India.

${ }^{2}$ E. HaHN, Alter der wirtschaftlichen Kultur, p. I23; and Entstehung der Pflugkultur, p. 40. 
over the clay, of the same lump to make one vessel unto honour and another unto dishonour?" (Romans IX. 20, 2I.) In ancient Egypt, the god Phtah fashions the egg of the world on a potter's wheel, setting it in motion with his feet. ${ }^{1}$ According to W. CROOKE, ${ }^{2}$ the potter of India regards the making of his vessels as a semi-religious art. The wheel he worships as a type of the creator of all things; and when he fires his kiln, he makes an offering and a prayer. He also makes the funeral jar, in which the soul of the dead man for a time takes refuge. Hence he is a sort of funeral priest, and in some parts of the country receives regular fees. It was a current notion in ancient China that the evolution of Heaven creates the beings in the same manner as the potter turns his objects of clay on the wheel. The potter's wheel was a symbol of the creative power of nature. In the ancient writers in whose works this conception looms up it appears as a purely philosophical abstraction; but it is obvious that the latter goes back to a genuine mythological idea, which, like everything mythical in China, is lost,the naive conception of the creator as a potter and thrower (as in the Old Testament). The potter's wheel was used also as a simile with reference to the activity of the sovereign. Yen Shi-ku, in his commentary on the Han Annals, quotes a saying that "the holy rulers by virtue of their regulations managed the empire in the same manner as a potter turns the wheel." It is therefore not impossible that religious speculations, centring around the cart-wheel and the fashioning of clay vessels and figures, might have had a prominent share in associating the wheel with the potter's activity, and given the first impetus to "throwing." If it can be maintained that the ancient Egyptians were the first to employ the potter's wheel, it may well be that the invention is due to the circle of the priests. Be this germ idea as it may, the culture-historical position of the potter's wheel is well ascertained. In view of the vast periods of human prehistory, it is a comparatively late invention, following in time the construction of the wheeled cart, being based on the cart-wheel, and made by man (presumably first by priests in illustration of a myth for religious worship) during the stage of fully-developed agriculture.

In the stage of hoe-culture or gardening, the occupation of woman, the potter's wheel is absent. Wherever it appears, it is correlated with man's activity in agriculture, based on the employment of the ox and plough. This feature is illustrated by both ancient China and India. The Emperor, or more correctly culture-hero, Shun (alleged 2258-2206 B.c.), in his youth, before he assumed charge of the administration of

1 E. A. W. BudGe, Gods of the Egyptians, Vol. I, p. 500, with colored plate.

2 Things Indian, p. 389 . 
the empire, is said to have practised husbandry, fishing, and making pottery jars: he fashioned clay vessels on the bank of the River, and all these were without flaw. ${ }^{1}$ The philosopher Mong-tse explained this act by saying that Shun continually tried to learn from others and to take example from his fellowmen in the practice of virtue. ${ }^{2}$ Another tradition crops out in the $K i$ chung Chou shu: ${ }^{3}$ here the incipient work in clay is attributed to the culture-hero Shen-nung, who, as implied by his name ("Divine Husbandman"), was regarded as the father of agriculture and discoverer of the healing-properties of plants. In this ancient lore we meet a close association of agriculture with pottery, and an illustration of the fact that husbandman and potter were one and the same person during the primeval period.

Likewise in ancient India the potter's trade was localized in special villages, either suburban or ancillary to large cities, or themselves forming centres of traffic with surrounding villages. ${ }^{4}$ Thus it is the case at the present day. When the writer, in I908, passed through Calcutta and desired to see a Hindu potter at work, he was obliged to drive several miles out of the city into a neighboring village. In fact, the potter is a peasant, and attends to his field during the rainy season, when he is unable to pursue his craft; he must have dry weather to harden his pots before they are fired..$^{5}$ According to Sir A. BAINES, ${ }^{6}$ the potter is one of the recognized village staff, and, in return for his customary share in the harvest, is bound to furnish the earthenware vessels required for domestic use. His caste is associated with the donkey, the saddle-animal of the Goddess of Small-Pox; and his donkey, when the kiln is not in operation, is employed in carrying grain and other produce. In most parts of the country the potters sometimes hold land, and in others take service in large households.

Likewise in ancient China the potter lived in close contact with the farmer, and received from him cereals in exchange for his products. ${ }^{7}$

${ }^{1}$ Chavannes, Mémoires historiques de Se-ma Ts'ien, Vol. I, pp. 72, 74; compare Bior, Tcheou-li, Vol. II, p. 462. See also Shi ki, Ch. I28, p. 5, where the commentary cites the Shi pen to the effect that Kun-wu (this volume, p. 39) made pottery.

${ }^{2}$ LegGe, Chinese Classics, Vol. II, p. 206.

${ }^{3}$ Chavannes, $l$. $c$., Vol. V, p. 457.

${ }^{4}$ R. Frck, Die sociale Gliederung im nordöstlichen Indien, pp. I79, I8I. Mrs. Rhys Davids, Notes on Early Economic Conditions in Northern India (Jourm. Roy. As. Soc., r9or, p. 864).

5 W. Crooke, Natives of Northern India, p. I35.

${ }^{6}$ Ethnography (Castes and Tribes), p. 65 (Strassburg, 1912; Encyclopadia of Indo-Aryan Research).

${ }^{7}$ According to Mong-TSE, III, I, $\S 4$ (LEGGe, Chinese Classics, Vol. II, p. 248). 
The farmer was in urgent need of these articles, which were in large demand; for "a single potter would not do in a country of ten thousand families, and could not supply their wants," and "with but few potters a kingdom cannot subsist." 1

The potter's particular residence is naturally determined by the sites of suitable clay, and his dependence on clay-digging excludes him from towns and cities. Thus A. K. Coomaraswamy ${ }^{2}$ observes, "The Singalese potters are found all over the country in every village affording the necessary clay, but often aggregated in greater numbers in places where an especially good supply of suitable clay is available. Thence the potter carries his pots for sale to more remote districts in huge pingo loads." The same holds good for China: all kilns are located in the country, and the potters supplying the wants of the villages and towns are farmers themselves.

The modifications brought about in the industry by the application of the wheel were fundamental and far-reaching. Technically they led to a greater rapidity and hence intensity of the process, but, above all, to many new features of form, consigning many others to oblivion. Likewise they resulted in a regularity, symmetry, harmony, and grace of shape, in a refinement and perfection unattained heretofore. The potter's art came in close touch and was set in correlation with other man-made industries, particularly with that of the bronze-founder, who furnished the potter with new ideas of forms and designs. ${ }^{3}$ The birth of artistic pottery was thus inaugurated. In passing from the hands of woman into those of man, the whole industry was imbued with a more active and vigorous spirit, and elevated to a higher plane by man's creative genius. It overstepped the narrow boundary of purely domestic necessity and developed into an organized system of carefully-planned and skilfully-directed manufacture on a large scale and with a wide scope. The ceramic work turned out by woman depended on local conditions, and catered to the narrow circle of the

${ }^{1}$ MonG-TSE, vi, $2, \S \S 3$ and 6 (ibid., p. 442).

${ }^{2}$ Mediæval Sinhalese Art, p. 2 r 8.

${ }^{3}$ W. Hougr (Man and Metals, Proceedings of the National Academy of Sciences, Vol. II, I916, p. 125) justly insists on the intimate connection of clay and metal working. The activity of the ancient sovereigns of China is likened not only to that of the potter, but also to that of the founder. Potter and founder 陶冶 are frequently mentioned together (for instance, by Mong-tse: LEGGE, Chinese Classics, Vol. II, p. 248). The correlation of the mortuary pottery of the Han with corresponding types in bronze has been shown by me in detail. The same phenomenon occurs in the prehistoric ceramic art of central Europe, where imported Roman bronze vessels were imitated and reproduced in clay (see particularly A. Voss, Nachahmungen von Metallgefässen in der prähistorischen Keramik, Verh. Berl. Anthr. Ges., Vol. XXXIII, I901, pp. 277-284). 
home community. The widened horizon of man led him to search for clays and other materials in distant localities, and to trade his finished product over the established routes of commerce in exchange for other goods. It was due to the introduction of the wheel that ceramic labor was afforded the opportunity of growing out of a mere communal, clannish, or tribal industry into a national and international factor of economic value. ${ }^{1}$

In the suburbs and villages around Peking, where pottery is manufactured, two kinds of wheel are in use. The two specimens illustrated on Plates XI and XII were secured near Peking by the writer in I903, and are in the American Museum of Natural History, New York. The one is made of a hat-shaped mass of clay, which is hardened by the addition of pig's hair and straw. This wheel is employed for turning out circular vessels of small and medium sizes, and may be regarded as the common, typical wheel used throughout northern China. The other wheel consists of a weighty stone disk made in the great industrial centre, the town Huai-lu in Shan-si Province. It serves for the making of round and heavy vessels of large dimensions. ${ }^{2}$ A round wooden board is placed on the stone disk as support or table on which the mass of clay is shaped. The difference between the clay and stone wheels, accordingly, is one of degree only, not of type; indeed, they represent the same type, and are identical in their mechanical construction. Both wheels revolve on a wooden vertical axis, the lower extremity of which is fixed into a pit, so that the upper surface of the disk lies on the same level as the floor of the shed in which the potter works. The latter squats on the ground in front of the wheel, and sets it in motion by means of a wooden stick, which is inserted in a shallow cavity near the periphery of the stone disk. While the disk continues to twirl, a lump of clay is thrown upon it and worked by the potter with both of his hands: he vigorously presses his thumbs downward, shaping the bottom of the jar, then draws them upward, and it seems as though by magic the walls of the vessel come running out of his

1 With reference to the La-Tène period, these changes are well characterized by $\mathrm{H}$. Schмid in his excellent article Keramik, in the Reallexikon der germanischen Altertumskunde, edited by J. Hoops (Vol. III, p. 36).

${ }^{2}$ Aside from China, stone wheels seem to occur in India, but only occasionally (H. H. Cole, Catalogue of the Objects of Indian Art in the South Kensington Museum, p. 201). H. R. C. DobBs (Journal of Indian Art, No. 57, p. 3) remarks that in the north-west provinces of India wheels are made either of clay, or stone, or wood, but most commonly of clay. The difference is merely one of durability: a clay wheel lasts about five years and can be made in four days without cost to the potter; a wooden wheel lasts for about ten years, being made by a local carpenter for Rs. I-8; a stone wheel will last a lifetime, and is usually brought from Mirzapur or Indore at an average cost of Rs. 4 . 
fingers. The procedure is exactly identical with the practice of the ancients, as described by H. BLÜMNER. ${ }^{1}$ I never saw a Chinese potter spinning the wheel with his left hand and simultaneously forming a pot only with his right. He will always swing his wheel first, and then use both hands for fashioning the vessel. This point is particularly mentioned, because several authors tell us that the potter at the same time works the wheel with his left hand and fashions the clay with his right. Thus A. ERMAN ${ }^{2}$ says, with reference to ancient Egypt, that the wheel was turned by the left hand, whilst the right hand shaped the vessel. The same is asserted with regard to the potter on Sumatra. ${ }^{3}$ If these observations should be correct, which may justly be doubted, the potters who behave in this manner can hardly be credited with common sense. If the wheel is once set spinning, a constant revolution of sufficient velocity may very well be maintained for from five to seven minutes, which would afford ample time for a skilful workman to turn out one or even several vessels by the use of both hands. There is no necessity whatever for his left hand to operate the wheel, and how the right hand alone could satisfactorily model a pot is difficult to see. In China, Japan, and India, at all events, the potter will always use both hands in this process; or he has a helpmate to attend to the wheel.

In his description of the porcelain-manufacture at King-te-chen, Père D'EnTREColles has alluded to the employment of the wheel, without, however, going deeper into the subject. ${ }^{4}$ In the King te chen $t^{\prime}$ ao $l u,{ }^{5}$ the wheel is described as a round wooden board, with a mechanism below, that effects a speedy revolution. The potter is seated over the wheel (literally, "he sits on the chariot" 拉者於事上), pushing it with a small bamboo stick, and moulding the clay with both of his hands. The illustrations reproduced by Julien after the first edition of ${ }^{8} 8{ }_{5} 5$ (Plates $\mathrm{V}$ and $\mathrm{VI}^{6}$ ) show the potter squatting at the end of two low benches, steadying his feet on the latter; but the mode of turning the wheel is represented in a different manner from the description in the text. In one illustration the potter avails himself of an assistant, who bends over a bench, and sets the wheel in motion with his left hand. In the other, the helpmate turns the wheel with his

1 Technologie, Vol. II, p. 39.

${ }^{2}$ Life in Ancient Egypt, p. 457.

${ }^{3}$ Encyclopædie van Nederlandsch-Indië, Vol. III, p. 32 r.

'DuHalde, Description of the Empire of China, Vol. I, p. 342; or S. W. Bushell, Description of Chinese Pottery, pp. I90-I9I.

${ }^{5}$ Ch. I, p. 18 b (new edition of $\mathrm{r} 89 \mathrm{r}$ ); compare Julien, Histoire, p. 146.

${ }^{6}$ Those of the new edition are different, and much coarser in execution. 
right unshod foot, while supporting himself by means of a rope suspended from the branch of a tree. The wheel itself is a cog-wheel, the projecting teeth being of a rectangular shape. ${ }^{1}$ The foot of the turner fits exactly into the space left by two teeth. This arrangement is identical with that of the small lead cylinders fixed around a Roman wheel of baked clay found near Arezzo in 1840 , and the pegs attached to the circumference of other wheels discovered in the vicinity of Nancy. ${ }^{2}$

The devices depicted in this Chinese book are obviously those of central and southern China. This is confirmed by an observation of E. S. Morse, who had occasion to see and to sketch a potter at work near Canton, and who points out the same rope contrivance. "The wheel rests on the ground, and the potter squats beside the wheel. A helper stands near by, steadying himself with a rope that hangs down from a frame above; holding on to this and resting on one foot, he kicks the wheel around with the other foot. The potter first puts sand on the wheel, so that the clay adheres slightly. He does not separate the pot from the wheel by means of a string, as is usual with most potters the world over, but lifts it from the wheel, the separation being easy on account of the sand previously applied. The pot is somewhat deformed by this act, but is straightened afterwards with a spatula and the hand, as was the practice of a Hindu potter whom I saw at Singapore." 3

Besides the plain wheel, as considered heretofore, another type occurs in China,-a wheel with double disks. In this case, there are two horizontal, parallel disks or wheels connected by a vertical spindle. The lower one, being of considerably smaller diameter, is operated by the feet of the workman, and accordingly turns the upper one, which is reserved as the potter's table. A similar device is described by Jesus Sirach in the third century B.c. ${ }^{4}$ The same principle is brought out in a potter's wheel found by Fabroni in 1779 at Cincelli or Centum Cellæ, in the neighborhood of Arezzo, in Italy. It is composed of two disks or tables, both placed horizontally, of unequal diameter, having a certain distance between them, and their centre traversed by a vertical pin, which revolves. The wheel discovered was part of one

${ }^{1}$ It is doubtless on this illustration that E. Zimmermann's (Chinesisches Porzellan, Vol. I, p. I79) description of the potter's wheel is based; but I do not believe that this type is common, at least I never saw it in any of the kilns which I had occasion to visit.

${ }^{2}$ H. BlÜMner, Technologie, Vol. II, p. 39.

${ }^{3}$ E. S. Morse, Glimpses of China and Chinese Homes, p. 199.

4 BlümNer, l. c., p. 38 , note 3 . 
of the disks, made of terra cotta, about three inches thick and eleven feet in diameter, with a groove all round the border. ${ }^{1}$

A double wooden wheel is occasionally employed by the potters in the north-west provinces of India and Oudh, but, curiously enough, the upper disk is the smaller one. It is about ten inches in diameter, and on it the clay is worked. The lower disk, two feet apart from the upper one, measures two feet across. The whole apparatus is placed in a pit about three feet deep, the smaller disk being on a level with the surface of the ground. The axle turns on a stone slab at the bottom of the pit, and is kept upright by a crossbeam with a perforation in the middle, through which it runs. The potter is seated on the edge of the pit, and turns the wheel by pressing the lower disk with his right foot. The motion of this wheel is more even and continuous than that of the single wheel, and is employed for the finer kinds of pottery at Rāmpur and Mirrut. ${ }^{2}$

The double wheel is used also in Java, where it is called prebot. It is composed of two wooden disks, one placed above the other, the upper one, of somewhat larger size, being revolved on the lower one. The upper one is styled "female board" (uncher wedok), the lower one "male board" (uncher lanang). The upper wheel, on which is placed a flat board for the clay to be moulded, is set in motion by means of the foot. ${ }^{3}$

F. BRINKLEY ${ }^{4}$ describes the contrivance of a double wheel in the hands of the potters at Arita in Hizen. It consists of a driving and a working wheel, fixed about twelve to fifteen inches apart on a hollow wooden prism. On the lower side of the driving-wheel is a porcelain cup that rests on a vertical wooden pivot projecting from a round block of wood over which the system is placed. The pivot is planted in a hole of such depth that the rim of the driving-wheel is slightly raised above the surface of the ground. Beside this hole the modeller sits, and, while turning the system with his foot, moulds a mass of material placed on the working-wheel. His only tools are a piece of wet cloth to smooth and moisten the vessel, a small knife to shape sharp edges, a few pieces of stick to take measurements, and a fine cord to sever the finished vase from its base of superfluous matter.

Sir ERnest Satow, ${ }^{5}$ describing the work of the potters of Tsuboya, observes that these use wheels of three different sizes. The smallest

${ }^{1} \mathrm{~S}$. BirCH, History of Ancient Pottery, p. 556.

${ }^{2}$ H. R. C. DobBs, Pottery and Glass Industries of the North-West Provinces and Oudh (Journal of Indian Art, No. 57, p. 4).

${ }^{3}$ Encyclopædie van Nederlandsch-Indië, Vol. III, p. 322.

4 Japan, Vol. VIII, p. 68.

${ }^{5}$ Korean Potters in Satsuma (Transactions As. Soc. of Japan, Vol. VI, 1878, p. 196). 
is formed by two wooden disks about three inches thick, the upper one being fifteen inches, the lower eighteen inches, in diameter, connected by four perpendicular bars somewhat over seven inches long. It is poised on the top of a spindle planted in a hole of sufficient depth, which passes through a hole in the lower disk, and enters a socket in the under side of the upper disk; and the potter, sitting on the edge of the hole, turns the wheel round with his left foot. The largest wheel is about twice the size of the smallest in every way. This description fits very well the illustration of a potter's wheel in the T'u shu tsi ch'eng (see Fig. 2), except that the two wheels are here connected by two vertical bars, and that the whole apparatus is above ground, so that the potter is obliged to stand.

Although the real study of Korean pottery remains to be made, ${ }^{1}$ the general development of the art in its main features can be clearly traced. We may distinguish four principal periods, - first, a prehistoric or neolithic period prior to the cultural contact of Korea with China, during which primitive vessels without the application of the wheel were turned out, that represent a uniform group with the prehistoric pottery found in the Amur region, Manchuria, Saghalin, and Japan ${ }^{2}$ second, the period of the Silla kingdom (57-924) heralded by the introduction of Chinese culture, in the wake of which the forms of the ancient Chinese sacrificial vessels as well as dishes for every-day use and the potter's wheel made their appearance; third, the Korai period (925-I392), centring around Song-do, where glazed pottery, also porcelain, was produced according to models and traditions of Chinese Sung ware; and, fourth, the modern period after I392. Here we are concerned only with the second or the first historic period, which is characterized by the novel feature of the wheel and by new and elegant shapes based on Chinese prototypes. We have authentic records in

${ }^{1}$ Compare in particular A. Billequin, Notes sur la porcelaine de Corée ( $T^{\prime}$ oung Pao, Vol. VII, I896, pp. 39-46); E. S. Morse, Catalogue of the Morse Collection of Japanese Pottery, pp. 25-3I, and the study of P. L. Jour, quoted below; J. PlatT, Ancient Korean Tomb Wares (Burlington Mag., Vol. XX, No. 106, 1912, pp. 222-230, 2 plates); Perrucci, Korean Pottery (ibid., I912, p. 82, 2 plates), and letter of J. Platr (ibid., I913, p. 298); A. Fischer, Oriental. Archiv, Vol. I, I9I I, pp. I54-I57, plate XXXIV).

${ }^{2}$ As to the Amur region, a great quantity of pottery fragments was dug up by G. Fowke in 1898 (compare his report Exploration of the Lower Amur Valley, Am. Anthr., Vol. VIII, I906, pp. 276-297); this collection is in the American Museum of Natural History, New York. The Japanese archæologist ToRII found similar material in eastern Mongolia and Manchuria (Journ. of the College of Science, Tōkyō, Vol. XXXVI, No. 4, pp. 49 et seq., and No. 8 of the same volume, pp. 9, 30-4I, 62-64, 7I, and plates XIV-XVIII, XXIII). Neolithic Korean pottery is described by Shōzaburi Yagi (Journ. Anthr. Soc. of Tōkyō, Vol. XXX, 1915, p. I78). 


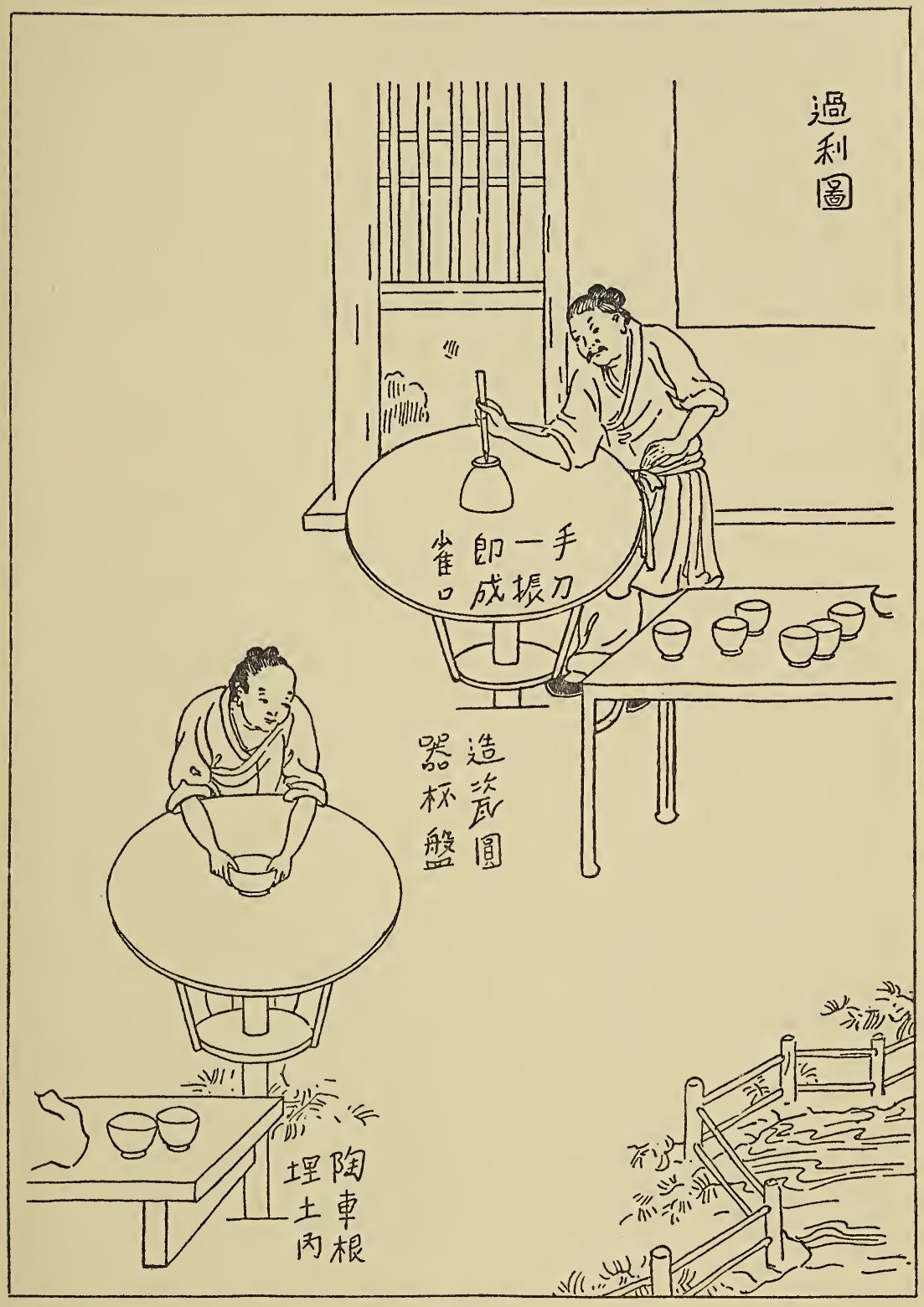

Fig. 2

Chinese double-Wheel PotTer's Lathe

(Sketch after $T^{*} u$ shu tsi ch'eng) 
regard to the adoption of the latter on the part of the Koreans; ${ }^{1}$ and as the greater part of the pottery of this period is turned on the wheel, ${ }^{2}$ while that of the preceding ages was fashioned only by hand, it is safe to assume that the introduction of the wheel is due to Chinese influence.

P. L. Jour writes on the Korean potter's wheel as follows: "The Korean potter's wheel consists of a circular table from two to three feet in diameter and four to six inches thick, made of heavy wood so as to aid in giving impetus to it when revolving. In general appearance it is not very unlike a modeller's table. This arrangement is sunken into a depression in the ground, and revolves easily by means of small wheels working on a track underneath, the table being pivoted in the centre. The wheel is operated directly by the foot, without the aid of a treadle of any kind. The potter sits squatting in front of the wheel, his bench or seat on a level with it, and space being left between his seat and the wheel to facilitate his movements. With his left foot underneath him, he extends his right foot, and strikes the side of the wheel with the bare sole of the foot, causing it to revolve." 3

A Japanese tradition credits the celebrated Korean monk Gyogi 行 基 (A.D. 670-749) ${ }^{4}$ with the invention of the potter's wheel. W!. G. Aston, ${ }^{6}$ W. Gowland, ${ }^{6}$ and F. BrinkLex ${ }^{7}$ have rejected this legend as unfounded by pointing out that the wheel was known in Japan

${ }^{1}$ Hou Han shu, Ch. I I5, and the writer's Chinese Pottery, p. 127. The Wo-tsü in Korea interred in the graves pottery vessels filled with rice. In this respect the Chinese account is of interest, that all the Eastern barbarous tribes, Tung I 東夷 availed themselves of dishes and platters (tsu tou 姐豆) for eating and drinking, with the sole exception of the Yi-lou or Su-shen ( $T^{*} a i p^{\prime} i n g$ huan yü $k i$, Ch. 175, p. 4 b). See also Kiu T'ang shu, Ch. 199 A, p. I.

P. L. Jouy, The Collection of Korean Mortuary Pottery (Report of the U.S. National Museum, 1887-88, pp. 589-596, particularly p. 591).

- Science, Vol. XII, I888, p. I44. Mrs. Bishop (Korea and Her Neighbours, Vol. I, p. 93) says, "The potters pursue their trade in open sheds, digging up the clay close by. The stock-in-trade is a pit in which an uncouth potter's wheel revolves, the base of which is turned by the feet of a man who sits on the edge of the hole. A wooden spatula, a mason's wooden trowel, a curved stick, and a piece of rough rag, are the tools, efficient for the purpose." A Korean drawing showing a potter at work is reproduced in Int. Archiv. f. Ethnogr., Vol. IV, r891, plate III, fig. 6.

- His life is briefly summed up by E. Papinot, Dictionnaire de géographie et d'histoire du Japon, p. I52. J. J. ReIN (Industries of Japan, p. 457) states only that Gyogi was the first to introduce the wheel into Japan, which may well be the original tradition, and that this event took place in A.D. 724 .

- Nihongi, Vol. I, p. I21.

- The Dolmen and Burial Mounds in Japan, p. 494.

${ }^{7}$ Japan, Vol. VIII: Keramic Art, p. 9. 
long before his time." Of course, Gyogi is not the "inventor" of the wheel, any more than Anacharsis the Scythian, or Hyperbius of Corinth, or Talus, the nephew of Daedalus. Nevertheless it may be that Gyogi, who, being a craftsman, was doubtless instrumental in the advancement of the ceramic industry in Japan, brought the specimen of a wheel along on his mission; and, if nothing else, this tradition would at least point to an introduction of the wheel from Korea. This is the natural course of events that we should expect, for the prehistoric pottery of Japan was solely made by hand. ${ }^{2}$ The early historic pottery found in the dolmens is wheel-shaped; but whether, with Gowland, it is to be dated in the beginning of our era, is a debatable point. E. S. MORSE $^{8}$ has offered another kind of convincing testimony for the fact that the early Japanese potter modelled by hand: the ancient practice is still continued in its prehistoric form in various parts of the empire, where many potters use only the hand in making bowls, dishes, or teapots. The vessels employed as offerings at Shinto shrines are usually made without the wheel, and are unglazed,- a phenomenon that we likewise meet in ancient Rome and in ancient India.

According to Morse, the typical form of the potter's wheel in Japan consists of a wooden disk fifteen to eighteen inches in diameter, and three inches thick. This is fastened to a hollow axis fourteen or more inches in length. A spindle with pointed end is planted firmly in the ground; and on this the wheel is placed, the spindle passing up through the hollow axis, and a porcelain saucer or cup being inserted in the wheel to lessen friction as it rests on the spindle. The wheel itself is on a level with the floor; and the potter, sitting in the usual Japanese position, bends over the wheel, which he revolves by inserting a slender stick in a shallow hole or depression near the periphery of the wheel. With a few vigorous motions of his arm the wheel is set in rapid motion; then, with his elbows braced against his knees, the whole body at rest, he has the steadiest command of the clay he is to turn. As the wheel slackens in motion, he again sets it twirling.

I I am unable, however, to admit Aston's statement that the text of the Nihongi to which he refers contains evidence of this fact. This evidence is negative or inconclusive, as the text in question speaks only of hand-made ( $t a-k u j i r i)$ small jars, which, according to Aston, should lead to the conclusion that "this was exceptional," and that fashioning on the wheel was the common practice of the time. In A.D. 588 the first potters came to Japan from the Korean state Pektsi (Aston, l. c., p. II7).

${ }^{2}$ E. S. Morse, Shell Mounds of Omori, p. 9; InjIma and SASAKI, Okadaira Shell Mound at Hitachi, pp. 2-5; N. G. Munro, Prehistoric Japan, p. I67.

${ }^{3}$ Catalogue of the Morse Collection of Japanese Pottery, p. 6.

Illustrations of the implements used by the Japanese brick-layer and potter may be seen in SIEBOLD, Nippon, Vol. VI, plate IV. 
The wheel is termed rokuro 曈䡷 (Chinese $l u$-lu), which properly means a pulley, windlass, capstan, then further a turning-lathe. The Japanese double wheel has been pointed out (above on p. r65).

If it is correct that the potter's art came to Burma from China rather than from India, and that glazing was acquired there from the Chinese either directly or through the medium of the Shan, ${ }^{1}$ it is probable also that the wheel reached Burma from the same centre. In the town of Bassein the double wheel is in use. ${ }^{2}$ In like manner it is probable that also the Annamese, who learned the entire process of porcelain-manufacture from their conquerors, the Chinese, adopted the wheel from the latter. ${ }^{3}$ The invasion of the outskirts of Tibet through Chinese potters working on the wheel has already been mentioned. They use a plain wooden wheel sunk into the ground, and work it with the foot. China, consequently, was the centre from which the art of wheel-made pottery radiated to all other countries of the East, in accordance with the diffusion of Chinese culture among the same peoples.

The great antiquity of the wheel in China cannot reasonably be doubted. As has been stated, it is alluded to in early writers of the pre-Christian era, and appears to have played a part in mythological conceptions. It is designated by a plain root-word, kün 均 or 鈞, which means also "even, level, harmonious." It was the instrument by means of which clay vessels were evenly balanced; it was a sort of "harmonizer." A description of the ancient wheel has apparently not come down to us. A commentator of Se-ma Ts'ien's Annals notes that it was seven feet high and provided with a plumb-line for adjusting the vessels. ${ }^{4}$ From Biot's translation of the Chou $l^{5}{ }^{5}$ it would seem as if the wheel were mentioned in that work, for we read, "Tout vase d'usage ordinaire doit être conforme au tour. . . Le tour est haut de quatre pieds. En carré, il a quatre dixièmes de pied." A potter's wheel of course is round, and everybody will be struck by the anomaly that the wheel should be four-tenths of a foot square. In fact, the text does not speak of a wheel, but of an instrument manipulated by the moulders. The passage runs thus: 器中轈膊崇四尺方四寸.

${ }^{1}$ Gazetteer of Upper Burma and the Shan States, Part I, Vol. II, pp. 399, 403. In support of this deduction, the fact is cited, that, in proportion to the population, there are more potters' villages in the Shan states than in Burma, and that in many places, notably in Papun, the potters are emigrant Shan.

${ }^{2}$ L. c., p. 400.

${ }^{3}$ A. DE Pouvourville, L'Art indo-chinois, p. 238.

${ }^{4} P^{\prime}$ ei wen yün fu, Ch. 5I, p. 77.

${ }^{5}$ Vol. II, p. 539. 
The word po, as far as I know, occurs only in this text as a potter's term. The commentator Ch'en Yung-chi 陳用之 explains it as "sliced meat" (切肉), saying that the potter's products should be like the latter, that is, as thin and smooth; and that the object of rendering a vessel equally thick and smooth is attained by the application of the instrument $p o$, which accordingly may have been a lathe. Cheng Ngo 鄭鍔, another commentator of the Chou li, remarks that it was of wood and placed on the side of the potter's wheel (kün 鈞), but his further description is not very lucid. At all events, the instrument in question was not, as conceived by Biot, a potter's wheel, which in fact is not mentioned in the text of the Chou li.

Almost all the round jars and vases of the Han period have been shaped on the wheel; and these ancient potters exercised considerable skill in its use. ${ }^{1}$ The profession of the throwers is emphasized in the ritual of the Chou dynasty (Chou li), and distinguished from that of the moulders. Moreover, we now have well-authenticated specimens of pottery of that period, which likewise exhibit the marks of the wheel. A truly neolithic, primitive, hand-made pottery, such as we have from Japan and Korea, has now also been traced in Chinese soil, particularly in southern Manchuria, Liao-tung, and Shen-si. I am inclined to date the use of the wheel in China back to a very remote age. The chief reason which prompts me to this conclusion is, that ancient Chinese records contain no traditions to the effect that pottery was ever the office of woman; on the contrary, they associate the industry exclusively with the activity of man, and these potters were agriculturists. The only ancient industry characterized as a female occupation is that of the rearing of silkworms and weaving. The "invention" of pottery, however, is ascribed to the mythical emperors Huang-ti, Shen-nung, and Shun; and throughout Chinese history we hear only of male potters. In fact, as we observe also at the present time, woman has no share whatever in this business. The potter's wheel, therefore, cannot be simply regarded as borrowed by the Chinese from the West in historical times, but it belongs to those primary elements of culture which the Chinese have in common with certain ancient forms of Western civilization. In our present state of knowledge, it is futile to endeavor to explain the how and why of this interrelation. There can be no doubt, however, that the ancient Chinese wheel has sprung from the same

${ }^{1}$ This is also the opinion of so prominent an expert in pottery as J. BRINCKMANN, the late director of the Hamburg Museum für Kunst und Gewerbe, who has written an excellent, though brief, article on Han pottery, especially with reference to its technique (Jahrbuch der Hamburgischen Wissensch. Anstalten, Vol. XXVII, 1909, pp. 96-102). 
source as that found in the West. Both are identical as to mechanical construction, even in minor points, and as to effect.

A comparatively great antiquity of the potter's wheel may be assumed also for India. Allusion has been made to the early mention of it in the Chatapatha Brāhmana (p. I 57). The jar employed for the ritual, as described by Kātyāyana, ${ }^{1}$ was solely formed by hand after the fashion of coiled pottery. This does not prove that the wheel was not in use at that time, for jars serving religious purposes were made by hand likewise in Rome and Japan, even after the introduction of the wheel. The case merely goes to show that handmade ware preceded the wheel-made fabric also in ancient India, and that the concept of a fundamental difference between the two was maintained, the hand-made product being reserved for religious worship.

The potter's wheel is twice mentioned in the Jattaka. ${ }^{2}$ In one story it is told how a Bodhisatva went to the king's potter and became his apprentice. One day, after he had filled the house with potter's clay, he asked if he should make some vessels; and when the potter answered, "Yes, do so," he placẹd a lump of clay on the wheel and turned it. When once it was turned, it went on swiftly till mid-day. After moulding all manners of vessels, great and small, he began making one especially for Pabhāvatī with various figures on it. The potter's work is a favorite simile in Buddhist scriptures. ${ }^{3}$

In this respect the following story is of particular interest: "In the town of Revata, in the north-west of India, there lived a masterpotter, who prided himself on his dexterity. He was waiting for the objects which he manufactured to dry on the wheel, and only at this moment he withdrew them. Knowing that the time of his conversion had arrived, Bhagavat (Buddha) transformed himself into a masterpotter, and, chatting with the other potter, asked him why he did not withdraw from the wheel the plates and utensils. The potter replied that he would do so, when they were perfectly dry. The Buddha transformed into a man said, 'Also I withdraw them, when they are perfectly dry. You and I follow the same procedure. I, however, have a special method. I withdraw the objects only after they are completely baked on the wheel.' The master-potter retorted, 'You

1 A. Hillebrandt, Ritual-Lit., Vedische Opfer, p. 8; L. D. Barnetr, Antiquities of India, p. 176 .

${ }^{2}$ Nos. 531 and 546 (Cowell and Rouse, The Jātaka, Vol. V, p. I5I; Vol. VI, p. I 88).

${ }^{3}$ For instance, Dighanikāya, II, 86 (R. O. Franke's translation, p. 79); T. Suzuki, Açvaghosha's Discourse on the Awakening of Faith, pp. 74, 75 . 
are more skilful than I am.' The Buddha transformed into a man said, 'Not only do I produce on the wheel objects completely baked, but also I can produce objects formed with the seven precious substances.' The master-potter's eyes were opened: he immediately received faith, and was converted. Thereupon Bhagavat, who had transformed himself temporarily into a potter, reassumed his proper body. He expounded the supernatural and subtle law, so that the potter's family was initiated into the four cardinal truths." 1

In southern India, wheel-made pottery came into general use during the iron age. ${ }^{2}$

The cart-wheel in the hands of the Indian potter has been referred to. This, however, is an exceptional local type, while commonly the wheel is a plain wooden disk. G. C. M. BIRDwood ${ }^{3}$ describes it as a horizontal fly-wheel, two or three feet in diameter, loaded heavily with clay around the rim, and put in motion by the hand; and, once set spinning, it revolves for five or seven minutes with a perfectly steady and true motion. The clay to be moulded is heaped on the centre of the wheel, and the potter squats down on the ground before it. The Tamil potters (Kusavans) are divided into two classes, northern and southern; the former using a wheel of earthenware, the latter one made of wood. ${ }^{4}$ Their badge, recorded at Conjiveram, is a potter's wheel. ${ }^{5}$ The Singalese wheel ( $p o ̈ r u v a)$ is a circular board, about two feet and a half in diameter, mounted on a stone pivot, which fits into a larger stone socket embedded in the ground; the horizontal surface of the wheel itself standing not more than six inches above the ground. The wheel is turned by a boy, who squats on the ground opposite the potter, and keeps it going with his hands. ${ }^{6}$

Ceramic art is very ancient in Iran, being alluded to in two passages of the Avesta. ${ }^{7}$ In the latter, mention is made of brick-layer's

${ }^{1} \mathrm{~J}$. Przyluski, Le Nord-ouest de l'Inde dans le Vinaya des Mūla-Sarvāstivādin et les textes apparentés (Journal asiatique, I9I4, nov.-déc., pp. 5I3, 5I4).

${ }^{2}$ R. B. Foote, Gov. Museum, Madras, Cat. of the Prehistoric Antiquities, p. III. In regard to South-Indian pottery compare also R. B. Foote, The Foote Collection of Indian Prehistoric and Protohistoric Antiquities (Madras, I9I4; new ed., 1916); and A. REA, Cat. of the Prehistoric Antiquities from Adichanallur and Perumbair (Madras, I915). F. W. v. Bissing (Sitzber. Bayer. Akad., I9I I, p. 16) seems to overvalue the antiquity of the potter's wheel in southern India; it is certainly out of the question that it should be older there than in Egypt.

${ }^{3}$ The Industrial Arts of India, Vol. II, p. I44.

4 E. Thurston, Castes and Tribes of Southern India, Vol. IV, p. I I3.

${ }^{5}$ Ibid., p. 197.

${ }^{6}$ A. K. Coomaraswamy, Mediæval Sinhalese Art, p. 2 I 9.

' Vidēvdāt, II, 32; viII, 84 . 
or potter's kilns. ${ }^{1}$ As a rule, the kiln is the natural consequence of the wheel; but it would be premature to conclude from this general observation that for this reason the wheel was known to the Avestans. It is not specifically mentioned in their sacred books; but that it was unknown cannot be deduced, either, from this silence.

The question of the antiquity of the potter's wheel in Babylonia seems not to be settled. PerRot and ChIPIEZ ${ }^{2}$ remark that the invention of the potter's wheel and firing-oven must have taken place at a very remote period both in Egypt and Chaldæa; that the oldest vases found in the country, those taken from tombs at Warka and Mugheir, have been burnt in the oven; that some, however, do not seem to have been thrown on the wheel. All that $\mathrm{HANDCOCK}^{3}$ states regarding the wheel is a reference to the article of Banks, whose theory of the origin of the wheel has already been characterized as unfounded (p. I54). In Palestine the wheel became general from the sixteenth century B.c. Likewise the Israelites were familiar with it, and turned almost all their vessels on the wheel. ${ }^{4}$ As has been mentioned, it is alluded to in several passages of the Old and New Testaments. ${ }^{5}$

In the graves of the Siberian bronze age has been found pottery of inferior workmanship, made by hand, of a coarse and badly baked clay. That from the graves of the iron age appears to be wheel-shaped, and abounds in artistic shapes. ${ }^{6}$ Its historical position is not yet exactly ascertained, but it appears to bear some relation to Scythian and Iranian cultures.

In ancient Egypt the wheel was known at the earliest epoch of history the sculptures of which have been preserved. ${ }^{7}$ It is depicted on the monuments, being of simple construction and turned with the hand.

${ }^{1}$ See also W. Geiger, Ostiranische Kultur, p. 390; and A. V. W. Jackson, From Constantinople to the Home of Omar Khayyam, p. 234. The Avestan word for the kiln, tanura (Middle and New Persian tanür) is regarded as a loan from Semitic tanür.

${ }^{2}$ History of Art in Chaldæa and Assyria, Vol. II, p. 298.

3esopotamian Archæology, p. 334.

${ }^{4}$ F. Vigouroux, Dictionnaire de la Bible, Vol. V, pp. 573-574; S. Birch, Ancient Pottery, p. I07. A photograph from Damascus of a potter at the wheel is reproduced in the National Geogr. Mag., I91 I, p. 67.

${ }^{5}$ Regarding the use of the wheel in Asia Minor, see W. BeLck, Z.f. Ethnologie, Vol. XXXIII, I901, p. 493.

6 W. Radloff, Aus Sibirien, Vol. II, pp. 89, 90, 129.

${ }^{7}$ J. G. Wilkinson, Manners and Customs of the Ancient Egyptians, Vol. II, pp. I90-I92 (new ed., by S. Birch), or 2d ed., Vol. III, p. I63. 
It is plausible that the invention spread from Egypt or Crete to Greece, and from there to Italy. ${ }^{1}$

The gradual dissemination of the wheel over Europe is vividly illustrated by the fact that in every culture-area there we encounter a primitive epoch of pottery-making, which shows no trace of the wheel, but a rude hand-made process. Such is found in the earliest stages of Hissarlik, the Homeric Troy, in Italy, central and northern Europe, and in the British Isles. During the second settlement of pre-Mycenæan Hissarlik (presumably before 2000 B.c.) we observe the beginning of the use of the wheel and the covered furnace. Throughout the Mycenæan period, pottery was turned on the wheel. The Swiss lake-dwellers, though capable potters, were unacquainted with the wheel. Likewise it was unknown in the British Isles during the bronze period. ${ }^{2}$ In the north of Europe, the potter's wheel appears at a late date in the La-Tène period. Thus the assumption gains ground that Egypt was the centre from which the wheel gradually spread to southern, and ultimately to central and northern, Europe.

In two areas of the Old World, accordingly, we can clearly observe a diffusion of the wheel from one point,- from China to her dependencies Korea, Japan, Annam, and Burma; and from Egypt to Europe. India was perhaps another focus, as far as Sumatra and Java are concerned. A direct transmission of the device from Egypt to India is conceivable, though it is of course impossible to furnish the exact proof. It is inconceivable, however, that the wheels of India and China should be independent from those of the West. Not only is there a perfect coincidence between their constructions and manipulations, but also the culture-associations by which the wheel is surrounded here and there are strikingly identical. The social setting of the wheel and the concomitant culture-elements have been characterized above. The wheeled cart, the highly-developed system of agriculture, bronze casting, and the affiliation of pottery with the latter, are features peculiar to the same area, and absent in other culture-zones. Consequently the presence of the wheel in the East and West alike cannot be attributed to an accident, but it appears as an organic constituent and ancient

1 Regarding details, see H. BlüMnER, Technologie, Vol. II, pp. 36-40; O. Schrader, Reallexikon, p. 868; etc. H. B. WALTERS (Cat. of the Greek and Etruscan Vases in the British Museum, Vol. II, p. 228) describes the medallion of a kylix on which a potter, nude and beardless, is seated before a wheel; on it is a kylix of archaic shape, the handle of which he is moulding. The question as to whether the wheel was employed in Crete at an earlier date than in Egypt, or vice versa, must be left to the decision of specialists in this field.

${ }^{2} \mathrm{~J}$. Evans, Ancient Bronze Implements of Great Britain, p. 487; British Museum Guide to the Antiquities of the Bronze Age, p. 43. 
heritage in the life of the Mediterranean and great Asiatic civilizations. This well-defined geographical distribution, and the absence of the wheel in all other parts of the globe, speak well in favor of a monistic origin of the device.

The chief results of the present investigation may be summarized as follows. The industry of ancient Chinese pottery, in its principal technical and social features, has exactly the same foundation as the corresponding industry of western Asia, Egypt, and India. This phenomenon is only one of a complex of others with which it is in organic cohesion; that is, the entire economic foundation of ancient Chinese civilization has a common basis with that of the West. ${ }^{1}$ It is a reasonable conclusion that identity of apparatus and technical processes must have yielded similar results. Comparative study of forms, however, is futile for the present, as long as we do not have the very earliest prehistoric ceramic productions of China, Central Asia, Iran, and India. This much is evident, that only by co-ordination can the real problem to be pursued be solved, and that isolation or detachment of each particular field will yield no result that is worth while. The incentive for the process of glazing pottery was received by the Chinese directly from the West, owing to their contact with the Hellenistic world in comparatively late historical times. The knowledge of glazing rendered the manufacture of a porcelanous ware possible; yet in this achievement the creative genius of the Chinese was not guided by outside influence, but relied on its own powerful resources. Nothing of the character of porcelain was known under the Han (206 B.C.-A.D. 220). The murrine vases of the ancients were not porcelain, and in fact bear no relation to China. They may have been instrumental, however, in bringing to the notice of the Chinese the beauty and effect of ceramic glazes; hence the manufacture of glazed ware springs up in the age of the Han, more particularly under the reign of the Emperor Wu ( $140-87$ B.c.). It is admissible to place the first subconscious gropings with ware of more or less porcelanous character in the closing days of the Later Han dynasty; and under the Wei, in the middle or latter part of the third century, we see these tentative experiments ultimately crowned with success. Continued till the end of the sixth century and the beginning of the seventh through a long line of experiences and improvements, they gradually resulted in the

1 The details are somewhat more developed in the writer's popular article Some Fundamental Ideas of Chinese Culture (Journal of Race Development, Vol. V, I9I4, pp. I60-174). 
production of a true white porcelain. Porcelain is not an invention, and there is no inventor of it. It is not in a category by itself, but is only a variety of pottery; its diversity from common pottery is one of degree, not of principle.

Finally, the question may be raised as to why Chinese records on all these points are so sparse and unsatisfactory. The same observation holds good for bronze, iron, wood-carving, basketry, and other ancient industries and crafts. The occupation with such themes on the part of Chinese scholars begins as late as the age of the Sung. The ancient professional annalists and chroniclers were not interested in the doings and thoughts of the broad masses of the people. If they recorded with some degree of exactness the invention of rag-paper in A.D. I05, it was for the reason that paper had a direct bearing on the life and work of the scholar. The plain farmer-potter of old led a secluded existence, far removed from the seats of scholarship. The average type of Confucian scholar never took an interest in technical questions, or else looked down upon these without a gleam of understanding. Our hopes for further elucidations of the problems connected with the history of pottery in China must be placed in archæology, not in sinology, which certainly reflects not on the sinologue, but on the character of the scanty source-material that has fallen to our lot. 



\section{INDEX}

Abel-Rémusat, 12 I.

Aeneas of Gaza, I42.

Africa, pottery of, I $5^{2}, \mathbf{1} 53$.

Ainu, pottery of, $149,150$.

Alaska, pottery of, I 49 .

Alchemy, I I3 note I, I I 8, I42-I43.

Amber, I3I.

America, potter's wheel absent, in, I5I; pottery, occupation of woman, in, $\mathbf{1 5 2}$.

Amur tribes, pottery of, I49, I66.

Analyses, of body of porcelanous Han pottery, 86; of Chinese and Japanese glazes, 90; of Chinese and Japanese porcelains, 86; of glaze of porcelanous Han pottery, 90; of green glaze of Han pottery, 93.

Andaman, unacquainted with potter's wheel, 152, I53.

Aristotle, I3I.

Assam, kilns of, I 56.

Aston, W. G., I68, I69.

Athenæus, I3I.

Atkinson, J. J., I5I.

Atlasov, W., I 50.

Augustus, 123 .

Australia, pottery unknown in, I49.

Avesta, pottery mentioned in, 173 .

Babelon, E., 129.

Bacon, 135 .

Baines, A., I 54, 160.

Banks, E. J., I 54.

Barber, E. A., I08.

Barbosa, I35.

Bartholomae, 126.

Batchelor, J., I50.

Bauer, M., I29.

Baumann, O., I53.

Belck, W., I74.

Berneker, E., I26.

Berthelot, M., I42.

Billequin, A., I 66.

Biot, E., 80, I54, I60, I70, I 7 I.

Birch, S., I65.

Birdwood, G. C. M., I54.

Bishop, Mrs., 168.

Bissing, F. W. v., I73.

Blümner, H., I27, I29, 133, I34, I64, I 75.

Boas, F., I 50 .

Bogoras, V., I 50, I 53.

Bostock and Riley, I23.

Boston Fine Arts Museum, porcelanous ware in, 82, 100.

Bretschneider, E., I I2, I I 5.
Brinckmann, J., I 7 I.

Brinkley, F., I65, I68.

Bronze, connection of with pottery, I6I.

Bronze-founder, influence of on potter, I6I.

Browne, Th., I35.

Bucaro, I3I note I.

Budge, E. A. W., I59.

Burma, pottery of, I 70.

Bushell, S. W., 95, 96, I01, I02, 124, I38, I40, I 55, I63.

Buttmann, Ph., I22.

Byhan, A., I50.

Cambodja, liu-li of, $\mathbf{I} 43$.

Cardan, J., I22.

Catapatha Brāhmana, I56.

Chang Yi, I I5, I I 8.

Chao Chang-li, 99.

Chavannes, E., 83, I I3, I24, I42, I44. I46, I49, I56, I60.

Che ngo, I I 5 .

Cheng lei pen ts'ao, II2, I I3.

Cheng Ngo, I 7 I.

Ch'en Yung-chi, r7 I.

Chou li, 80, I54, I70, I7 I.

Chou Shan, I46.

Chu Yen, I54.

Chuang-tse, I I 7 .

Chukchi, pottery of, I5O, 153 .

Cole, H. H., I Io, I62.

Compton, H., I54.

Cooking-stove, of iron, 79, 80.

Coomaraswamy, A. K., I10, I6I, I73.

Corsi, F., I29.

Court, pottery destined for the, ror.

Couvreur, S., ro5, I 7.

Crooke, W., 96, I59, I60.

Crucibles with natural glaze, $\mathbf{1 4 6 .}$

Dal, V., I25, 126.

Dalton, O. M., I37.

Ditmar, K. v., I 50 .

Dobbs, H. R. C., I62, I65.

Double wheel, used by potters of China. I64; in Java, I65; in Japan, 165; in Burma, I 70.

Easter Island, pottery of, 149 .

Eggeling, J., I 56.

d'Entrecolles, 163 .

Erman, A., I63.

Eskimo, pottery of, I49-150.

Evans, J., I75. 
Fabricius, B., 125, 138 .

Fagfur, I26.

Fan yi ming i tsi, I 39 .

Farfor, Russian designation for porcelain, 126.

Ferrand, G., I 43.

Fick, R., I60.

Fischer, A., I66.

Fluor-spar, 122.

Foote, R. B., I73.

Forke, A., I4I.

Fourdrignier, E., I36.

Fowke, G., I66.

Franke, R. O., I 72.

Freer, C., 82, 100.

Fu-chou, cinerary urns from, 84 .

Fu-nan, I43.

Gait, E. A., 156.

Gammon, C. F., 82, 83.

Geerts, A. J. C., I I 8 , I 45.

Geiger, W., 174.

Gilyak, pottery of, 149 .

Glass, 138 note $4,142,147$.

Glazes, introduction of into China, I 20-I 47.

Glazing, ancient Chinese recipe for, I 35 .

Gowland, W., I 68.

Grandidier, E., 108.

Grenard, F., I50.

Gurdon, Major, I 53.

de Groot, Ior.

Hager, J., I 21 .

Hahn, E., I 58.

du Halde, I63.

Han art, definition of, $8 \mathrm{r}$.

Han pottery, $79-81$, 92, I $43-144,171$; mentioned in Chinese records, I44 note 2.

Han-tan, kaolin of, II 3 .

Han ts'e, porcelanous ware of the Han period or of Han style, 79, Ior.

Han wu ku shi, I4I.

Handcock, I 74 .

Hang mountains, I I6.

Harrington, M. R., I 53.

d'Herbelot, 126.

Herzfeld, E., 97.

Hillebrandt, A., 172.

Hing chou, porcelain of, 99.

Hippisley, 102.

Hirth, F., I03, I05, I I I I I 3, I23, I30, I 39

Ho-nan, porcelain of, 99.

Hobson, R. L., 84, 95, 98, 99, I01, I04, I08, I I 2, I 20, I 44, I 45, I 46, I48.

Holder, E., I 55 .

Holmes, W. H., I 5 I.

Holt, H. F., 84 .

Hou Han shu, Ioo, 168.

Hough, W., I6I.

$\mathrm{Hu}$ Ch 'ung, I 43.

$\mathrm{Hu}$ Tsung, 140 .

Hü-chou, pottery of, Io6.
Hü K'ang-tsung, I49.

Hua yang hien chi, I44.

Hua yang kuo chi, II 5 .

Huai-lu, manufacture of stone disks in, I62.

Huai-nan-tse, 156.

Huang-chi, I43.

I-tsing, 95, 96.

Ides, E. Y., I 36.

India, liu-li of, 140, I43; porcelain in, 95-96; potter's wheel of, I56-157; social position of potters in, 154 .

Iran, pottery in, I 73-I 74 .

Jackson, A. V. W., I 74.

Jade, not to be understood by murrines, I 2 I.

Jao chou, kaolin of, I I 3 ; porcelain of, 99.

Japan, double wheel of, I65; potter's wheel of, I58, I69-I70; prehistoric pottery of, 150.

Japan Society, Catalogue of Potteries published by, 103 .

Jãtaka, potter's wheel in the, $\mathbf{1} 72$.

Java, double wheel of, I65; potter's wheel of, 152.

Jeremiah, I 58.

Jouy, P. L., 168.

Julien, S., $86,87,97,99$, I01, 102, 104, I07, 108, I I 5, I 1 $8,123,145,147,163$.

Juvenalis, I24.

Kaempfer, E., 136.

Kamtchatka, pottery of, 150.

Kaolin, notes on, I IO-I I 9.

Karakhoto, pottery of, 146 note 4 .

Karlbeck, O., 84.

Kātyāyana, I 72.

Kennedy, J., I37.

Kershaw, F. S., 82, 83.

Khasi, pottery of, 153 .

Ki chung Chou shu, I6o.

Kin, palace of, 146.

King te chen t'ao lu, 97, 98, ror, 105, I06, I63.

Kitsi, kiln of, 149.

Kiu T'ang shu, 168.

Kloss, C. B., I 53.

Koptos, scented pottery of, I3I.

Korea, pottery of, I66-I67.

K'ou Tsung-shi, II3, I I4.

Krause, J. H., I3I.

$\mathrm{Ku}$ kin chu, I4I.

Kuan-chung, kilns of, 101, I02.

Kuang chi, I43.

Kuang ya, II 5 .

Kuo I-kung, I43.

Kuo P'o, I I4, I I8.

Kuriles, pottery of, 150.

Lang, E., I 54

Le Compte, L., 136. 
Le Coq, A. v., 126.

Lei, type of jar, 79, 80 .

Legendre, A. F., I 49.

Legge, J., I0I, I I7, I60, I6I.

Lesson, A., 149.

Li ki, I 17.

Li Shao-kün, I 42.

Li Shi-chen, I I 2, I I3, I I4, I I5.

Liang shu, I 42, I43.

Liao shi, I05.

Lie-tse, I 5 note 5 .

Ling piao lu i, I I3, I47.

Liu $\mathrm{Hi}$, I 16.

Liu-li, I38-I47.

Liu-li kü, kiln of, 145 .

Liu Sün, I I3, 146.

Lui-li wa, Ioo.

Lo-lo, unacquainted with pottery, I49.

Loadstone, I04, I06.

Lu Kuang-wei, I I6.

Lubbock, J., I5 I.

Malayans, potter's wheel of, 152 .

Man, E. H., I52, I 53.

Mariette, P. J., I22.

Martialis, I24, I29.

Mason, O. T., I5I.

Mastidi, I26.

Mei Piao, II5.

Melanesia, pottery of, I49, I53.

Mély, F. de, I04, I 7 .

de Mendoza, I36.

Mineralogy, Chinese work on, I I5.

Mo-ch'u,=Javanese mojo, I43 note 6.

Mong $K$ 'ang, I44, I 45 .

Mong-tse, I6o, I6I.

Mongol dynasty, glazed pottery of, $\mathbf{I} 45$.

Morse, E. S., I64, I66, I69.

Mu-nan, I40.

Munro, N. G., I69.

Murdoch, J., I 50.

Murra, I25, I28, I38, I 45.

Murrine vases, $120-138$.

Nan chou i wu chi, 145 .

Nanjio, Bunyiu, I I 5 .

Negrito, unacquainted with pottery, I49.

Negroes, unacquainted with potter's wheel, I52.

Neuhof, J., I36.

New Zealand, pottery unknown in, 149.

Nichols, H. W. , technical report of, 86-94.

Nicobar, pottery of, I53.

Nihongi, 168.

Nordenskiöld, A. v., I2 I.

Nordenskiöld, E., I5I.

Okakura, 82 .

Pai ngo, I I I-I I 4, I I6.

Pai shan, I I4-II5.

Pai tun-tse, I 18 .

Palladius, I00, 105, I06, I38.
Pan-liang coins, 82, 83, 100.

Papinot, E., 168.

Parthians, kilns of, 122, 127, 126.

Pausanias, $125,137$.

Pelliot, P., I43.

Pen ts'ao kang mu, I04, II2, I I3, I I4.

Pen ts'ao yen i, II 3 , I I 4 .

Periplus I21, 137. I38.

Perrot and Chipiez, 174.

Petrie, W. M. F., 137, 138, 139, 147.

Petrucci, I66.

Petuntse, I I0, I I I, I I 8-I I9.

Pie lu, I I3, I I4, I I 8 .

Platt, J., I66.

Pliny, I06, I $21,124,127$, I3 I, I32, I34.

Po Kü-i, I46.

Polar peoples, pottery of, I49-I50.

Polynesians, unacquainted with pottery, I 49.

Pompey, I23.

Porcelain, in India, 95-96; no inventor of, 99; of Ts'e-chou, 104, 106.

Porcelanous Han pottery, analysis of body of, 86; analysis of glaze of, 90 ; chemical character of body of, 86; mode of preparation of glaze of, 91 ; physical character of body of, 87 .

Potter's wheel, see wheel.

Pouvourville, A. de, I70.

Prestwich, I Io.

Propertius, I22, I24, 126.

Przyluski, J., I73.

Quichua, pottery-making of, $\mathbf{1}_{5} \mathrm{I}$.

Radloff, W., 126, I74.

Rea, A., I 73 .

Reil, T., I3I.

Rein, J. J., I68.

Reinaud, M., 97.

Rhys Davids, I6o.

Rinsō, Mamiya, I49.

Risley, Sir Herbert, I48, I 54 .

Rock-crystal, theories on the origin of, I31; vessels of, 132, 133, I37.

Rockhill, W. W., I5o.

Roloff, E. H., 122, 125.

Romans, I59.

Rondot, N., 99, 123.

Saddle, of liu-li, I42.

Saghalin, pottery of, 149 .

Salvétat, A., 86, 87, 90.

Samarra, excavations in, 97-98.

San kuo chi, I40.

Säroshevski, I52.

Sarre, F., 97, 98.

Satow, Sir Ernest, I65.

Scaliger, J. C., I22.

Scaliger, J. J., 122.

Scented pottery, I3I.

Schmidt, H., I62.

Schrenck, L. v., I 49. 
Schurtz, H., I 53 .

Seger, H. A., 86, 87.

Seligmann, C. G., I5I, I 53.

Se-ma Siang-ju, I I5.

Se-ma Ts'ien, I 16, I24, I42.

Se-tiao, 143.

Shan hai king, I I4, I I6, I I 8 .

Shen-nung, 160.

Shi i ki, I4I.

Shi ki, I I 5, I24.

Shi king, alleged porcelain whistle in, Ior.

Shi ming, I I6.

Shi yao erh ya, I 15 .

Shu king, pottery not mentioned in, I02.

Shun, mythical originator of pottery, I 59-I 60.

Shuo wen, definition of the term ts ${ }^{\circ}$ in, I02-103; definition of the term ngo in, I 16.

Si king tsa ki, $\mathbf{1} 42$.

Siberia, pottery of tribes of, I49, 174 .

Siebold, P. F. v., I 49, I69.

Singalese, potter's wheel of, I 5I ; potters of, $\mathrm{I} 6 \mathrm{r}$.

Smith, F. P., II 7 .

Smith, W., I 30.

Soleyman, 96, 97.

Sprenger, A., I26.

Squier and Davis, I6I.

Stage-fool, I 7 note 2.

Statius, 124.

Stein, Sir Aurel, 98, 146.

Strahlenberg, P. J. v., I 50.

Stull, R. T., 93.

Su chou fu chi, I 6 .

Su Kung, I 13 .

Su-shen, I68 note I.

Su Sung, I I3, I I4.

Suetonius, 123.

Sumatra, potter's wheel of, 152 .

Suzuki, T., I 72.

Ta T'ang sin yü, 98 .

Ta-ts'e, mountains of, II4.

Ta Ts'in, I38, I39, I43.

Ta Ts'ing i t'ung chi, 84 , 104 .

T'ai p'ing huan yü ki, 99, I04, 107, I43, I 68.

T'ai p'ing yü lan, I4I, I42, I43, I 45 .

Takakusu, J., 96.

T'ang leu tien, 99.

T'ang pen ts'ao, II2.

T'ang pen yü, II 12 .

T'ang period, porcelain of, 99 .

T'ang Shen-wei, II2.

T'ang shu, 99, 104, 105.

T'ang shu shi yin, I 16.

T'ao Hung-king, I I I - I I 3 .

T'ao shuo, 96, 98, I24, I45, 155.

Taoists, share of in the initial production of porcelain, 118 .

Thiersch, F., I22, I25, I28, I29, I32, 134.
Thurston, E., I 55, I 73.

Tibet, pottery of, I50.

Ting chou, porcelain of, 99; kaolin of, I 3 .

Ting Tu, I07.

Torii, I50, 166.

Ts'ai Yung, ror.

Tse jan hui, I45.

Ts'e, does not refer to common glazed Han pottery, Ioo; discussion of the term, 102-I09.

Ts'e-chou, city of, I04, I07 note.

Tse sü fu, II 5 .

Tsi yün, 107, 146.

Tsin shu, I4I.

Tsien Han shu, 107, II5, I40, 143, 145.

Ts'ui Yung, 146.

Ts'ung-lung, mountains of, I I 4 .

T'u king pen ts'ao, I I 4 .

T'u shu tsi ch'eng, ro5.

Tung-fang So, I 42 .

Turkistan, porcelain in, 98 .

Tu tuan, Ior.

Tylor, E. B., I 49.

Vedda, pottery of, I5I, I53.

Vigouroux, F., I 74 .

Voss, A., I6I.

Walters, H. B., I75.

Wan Chen, 145 .

Wang Hui, I46.

Watt, G., I Io.

Watts, A. S., I 10.

Watters, T., I I 5 .

Wave patterns, $8 \mathbf{I}$.

Wei lio, 138 .

Wheel, potter's, I48-176; absent in America, I50-15I; associated with the stage of agriculture, I59-I6I; geographical distribution of, I50; in Egypt, I59, I63, I74; in Old Testament, 158 ; in Palestine, 174 ; influence of on progress of ceramics, I6I-I62; invention of man, I52-155; of ancient Europe, 175; of Babylonia, I54, I74; of China, I62-164, I71, I75; of India, I $55^{-1} 57,172$; static in its distribution, I5I; technical connection with cartwheel, I56-I 58.

Wheel-potters and moulders, distinct professions in ancient China and India, 154.

White, M., I 55 .

Wieger, L., I I5, I 17.

Wilkinson, J. G., I74.

Window-glass, I 4 I.

Wo-tsü, burial customs of, I68 note I.

$\mathrm{Wu}$, Emperor, I40, 142.

Wu li, I 43.

Wu P'u, I I5, I I8.

Wu p'u pen ts'ao, II5. 
Wu ti ki, II6.

Wylie, A., I 15.

Yakut, pottery of, $\mathbf{1} 52$.

Yang-shan, II6.

Yellow, color of earth, II4.

Yen Kan-yüan, 79, 80, I0I.

Yen Shi-ku, I I6, I45, 159.

Yi ts'ie king yin i, 96, II5, I3I, I39.

Yu ngo, II7.
Yu yang tsa tsu, 98, I 40 .

Yüan kien lei han, 143 .

Yüan Ying, 96, I15, I3I, I39.

Yu chou, porcelain of, 99.

Yü t’ang kia huo, 146 .

Yüan shi, 105, I45.

Yüe chou, porcelain, of, 99.

Yule, H., I26, 135 .

Zimmermann, E., 99, 164 . 



Plate I.

Han Porcelanous Pottery (see p. 79).

Small jug. The yellowish-green, vitrified porcelanous glaze covers only the medial portion of the body, inclusive of the two ears or loop handles. The exterior of the neck and the base are unglazed. In the base, nail-marks are left. The bottom is flat and without a rim. The clay appears to contain iron ore. Found on top of a cast-iron stove (Plate II), in a grave near the village Ma-kia-chai, $5 \mathrm{li}$ north of the town Hien-yang, Shen-si Province.

Middle or end of the third century A.D

Height, $16.7 \mathrm{~cm}$.

Cat. No. II 87 I8. 


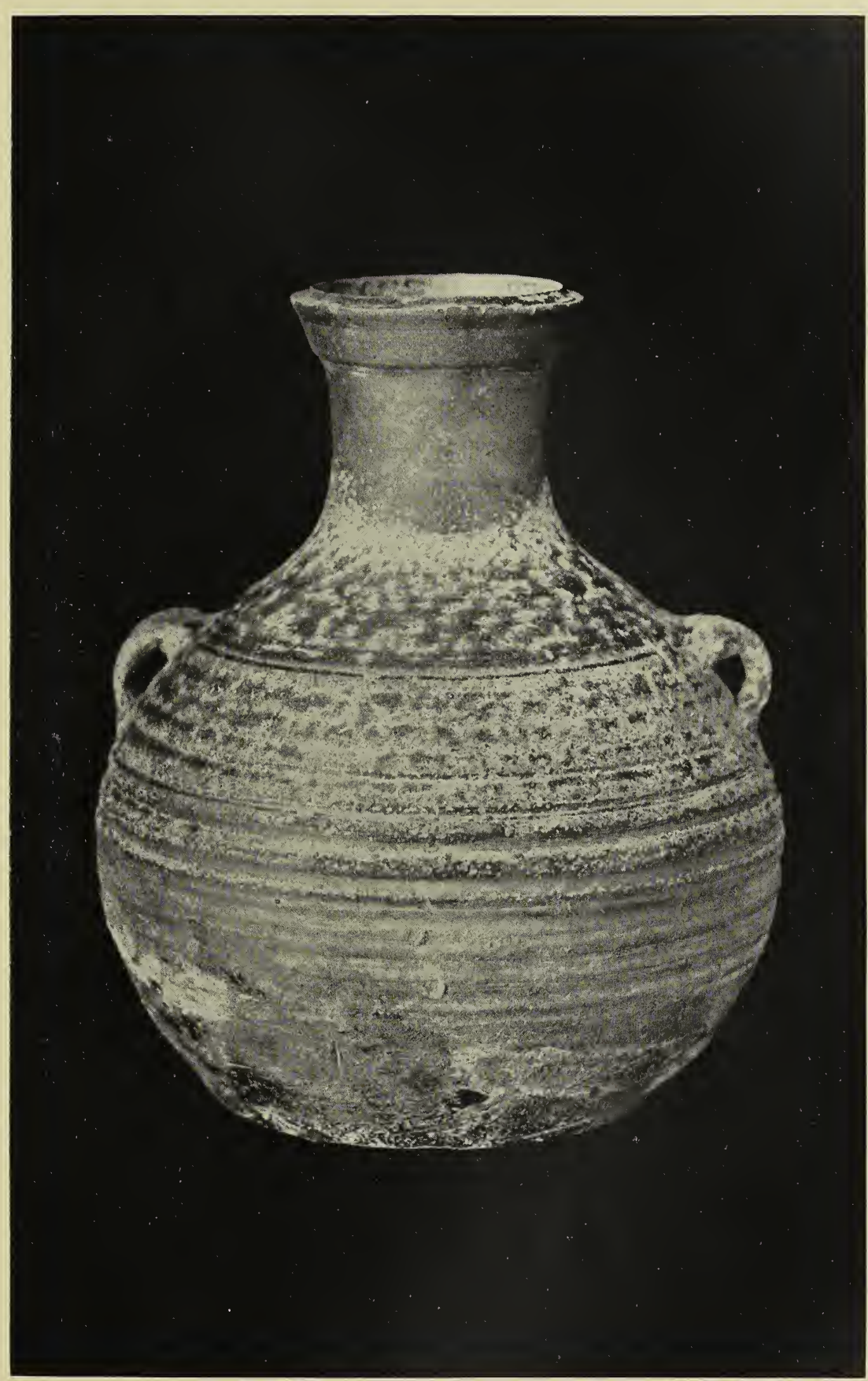

han Porcelanous Jug. 




\section{Plate 11 .}

Cast-Iron Stove (see p. 80).

Side and front views.

In type and style it exactly corresponds to the Han pottery burial cookingstoves. Posed on four feet in the form of elephant-heads, it is built in the shape of a horse-shoe, and provided with a chimney, five cooking-holes, and a projecting platform in front of the fire-chamber. On the latter is cast an inscription consisting of six raised characters in Han style of writing, reading ta ki ch'ang $i$ hou wang ("Great felicity! May it be serviceable to the lords!"); see p. 79. The iron core is entirely decomposed, so that for exhibition purposes the object had to be braced on wooden supports. Found in a grave near the village Ma-kia-chai, 5 li north of the town Hien-yang, Shen-si Province. Inserted here as collateral evidence in determining the provenience and date of the pottery jug illustrated in Plate I.

End of Han period (A.D. 220), or, generally, third century A.D.

Height, $35 \mathrm{~cm}$; length, $71.5 \mathrm{~cm}$; width, $40.5 \mathrm{~cm}$. Cat. No. 120985 . 

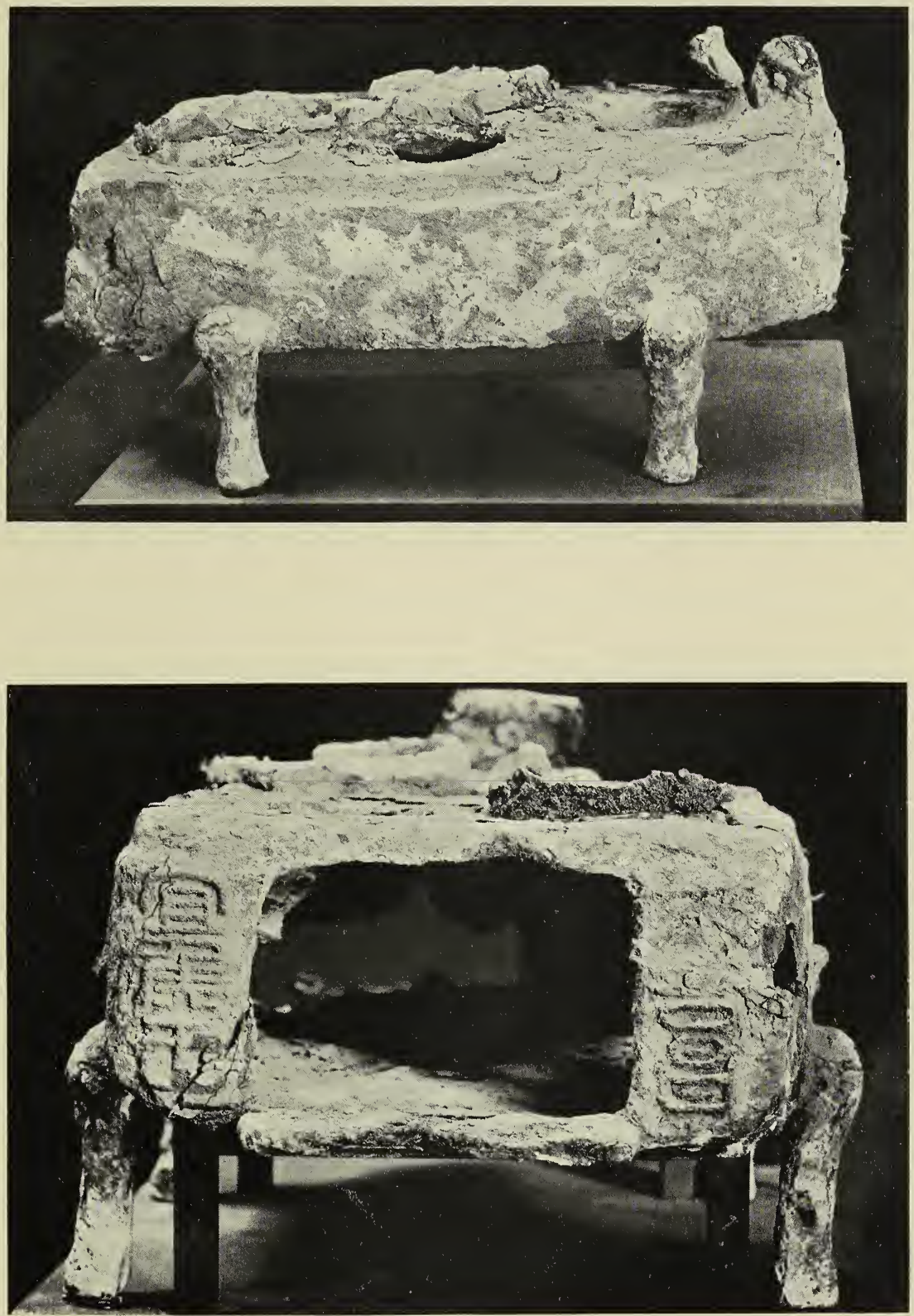

CAST-IRON STOVE. 


Plate III.

Han Porcelanous Pottery.

Small jug. The interior of the neck is glazed in its upper part. Only the upper portion of the body is coated with a thick, lustrous, porcelanous glaze of greenish-yellow tinge, interspersed with small white dots, the glaze running down in streaks over the lower unglazed part. This is the best-glazed piece in the lot. Two rounded ears or loop handles are attached to the shoulders.

Middle or latter part of third century A.D. Height, $20.1 \mathrm{~cm}$.

Cat. No. I 18723 . 


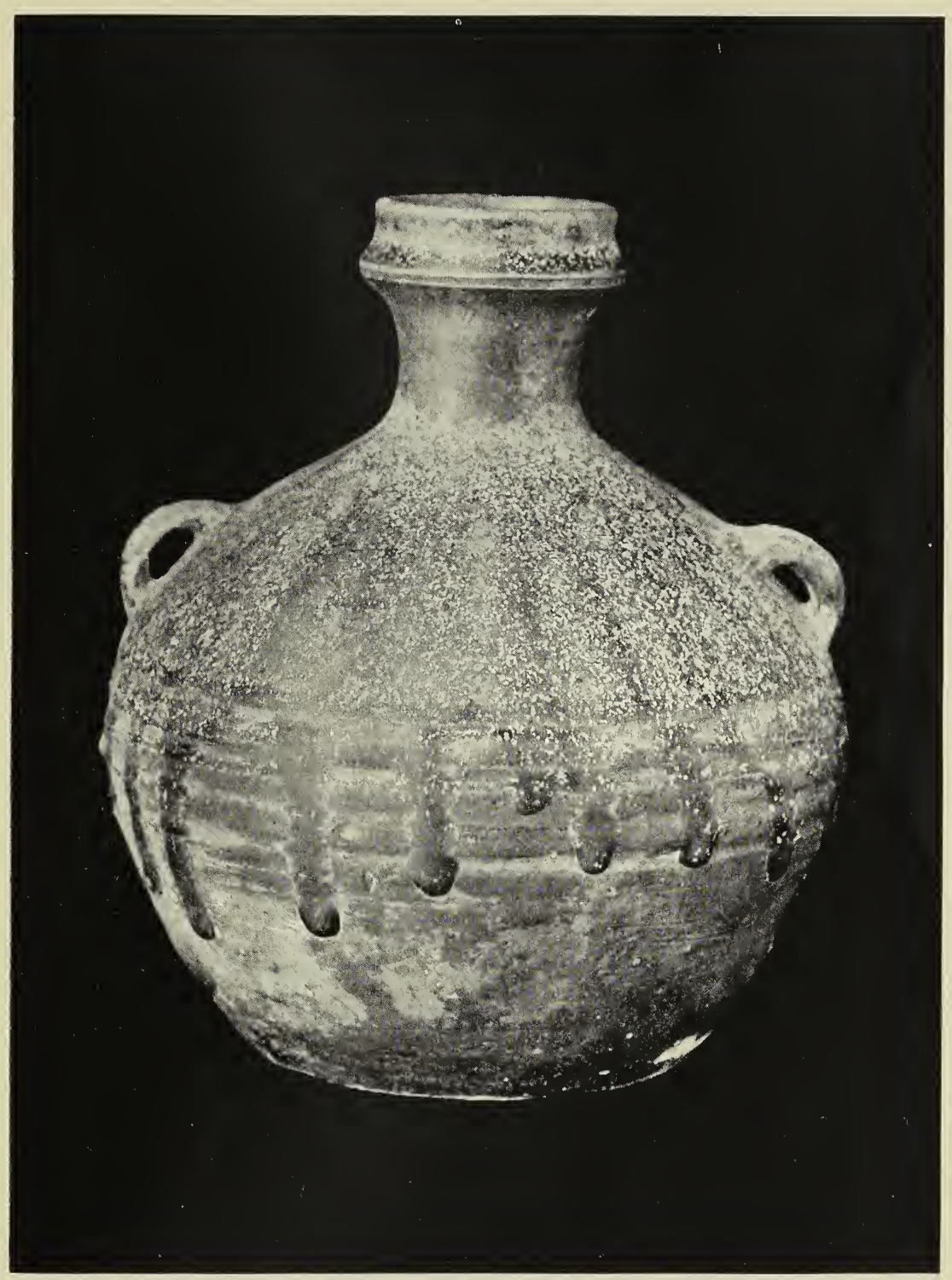

HAN PORCELANOUS JUG. 




\section{PLATE IV.}

\section{Han Porcelanous Pottery.}

Large globular vase of harmonious proportions, decorated with two opposite animal (tiger)-heads in flat relief, holding dead rings, of the same style as in common Han pottery. In the middle between these heads, but somewhat higher, and opposite each other, are two semi-circular loop handles stuck on to the body of the vessel, obviously for the passage of a cord, by means of which the vase was held and carried. Each handle is bordered by two knotted bands moulded separately in high relief. This feature, - that is, the combination of loop handles with tiger-heads, - to my knowledge, does not occur in ordinary Han pottery. The slip appears to have been lost in part of the neck. The glaze exhibits various tinges of light green, mingled with the deep brown of the slip, and interspersed with black spots, the brown approaching that of maple-leaves in the autumn. The red-brown slip covers one side of the neck and almost the entire base; in the middle portion the porcelanous glaze appears to be laid over this slip. Three bands, each consisting of three concentric grooves, in the same manner as in Han pottery, are laid around the body. The bottom is flat, and has along the rim a broad grayish ring of irregtular form and depth. The walls of the vessel are unusually thick, and its weight is almost six pounds.

Third century A.D.

Height, $35.4 \mathrm{~cm}$.

Cat. No. Ir8720. 


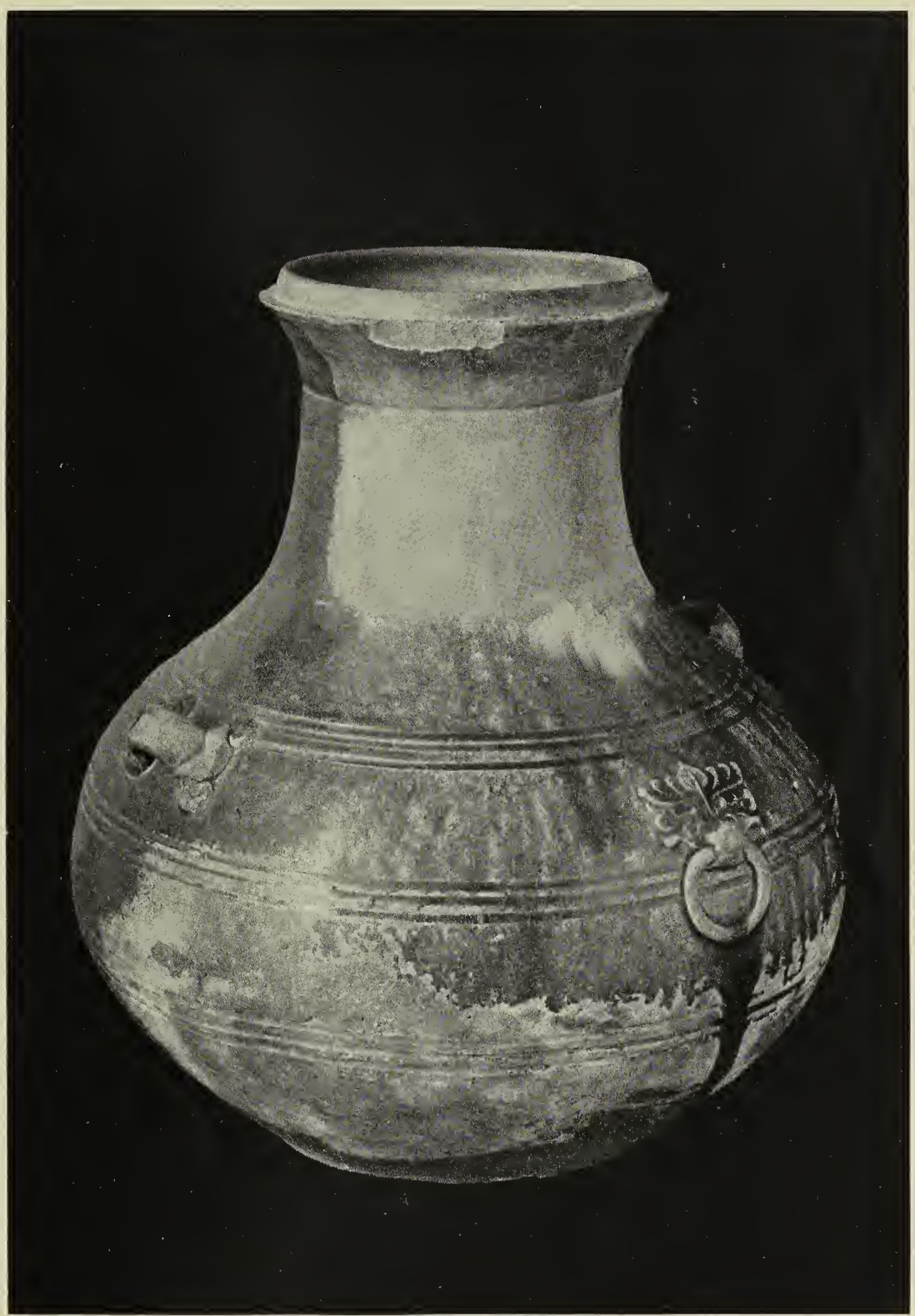

han Porcelanous VAse. 




\section{PLATE V.}

\section{Han Porcelanous Pottery.}

Small jar, now unglazed, but originally glazed in its middle portion; when found, covered all over with masses of earth, the glaze having been destroyed by chemical influences under ground, and a white engobe being left in its place. A wave-band, each consisting of five lines, presumably done by means of a roller, runs around the upper rim and the neck. A double knot in low relief is stamped above the loop handles, which terminate in a flat ring filled with incised, radiating lines, apparently the reproduction in clay of a metal ring. The bottom is raised on a rim, about I $\mathrm{cm}$ high.

Third century A.D. 


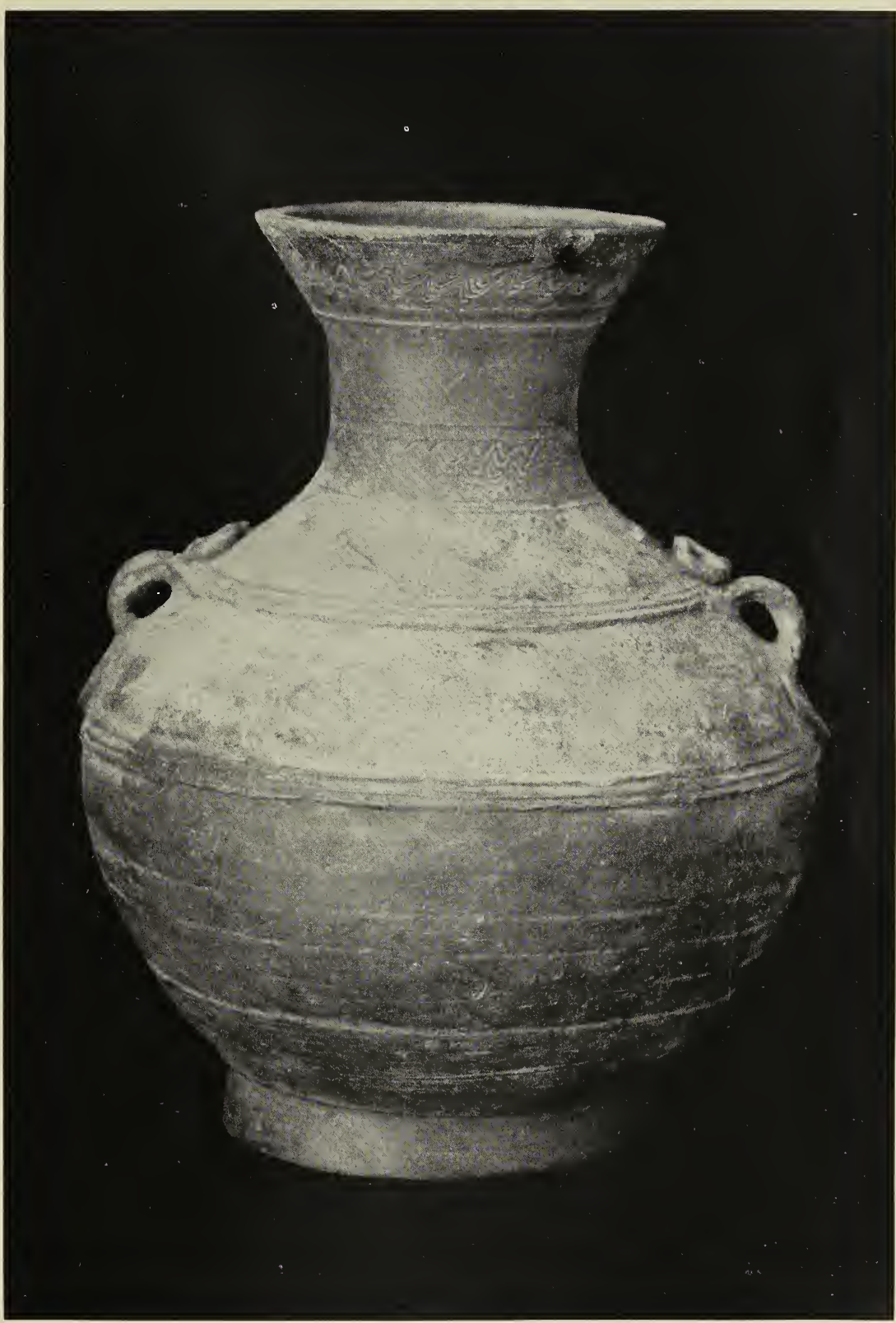

HAN PORCELANOUS JAR. 




\section{PLATE VI.}

Han Porcelanous Pottery.

Globular vase, slightly asymmetrical, a narrow medial zone reaching from the neck down to the shoulders being well coated with a uniform, lustrous, yellowishgreen porcelanous glaze; the neck and base showing a glossy brown slip. Its interior is glazed over a space of $6 \mathrm{~cm}$. Decorated with three incised wave-bands, bordered by deep grooves, the lower one under the glaze. The almost semi-circular loop handles exhibit a leaf or fish-bone design.

Third century A.D. 


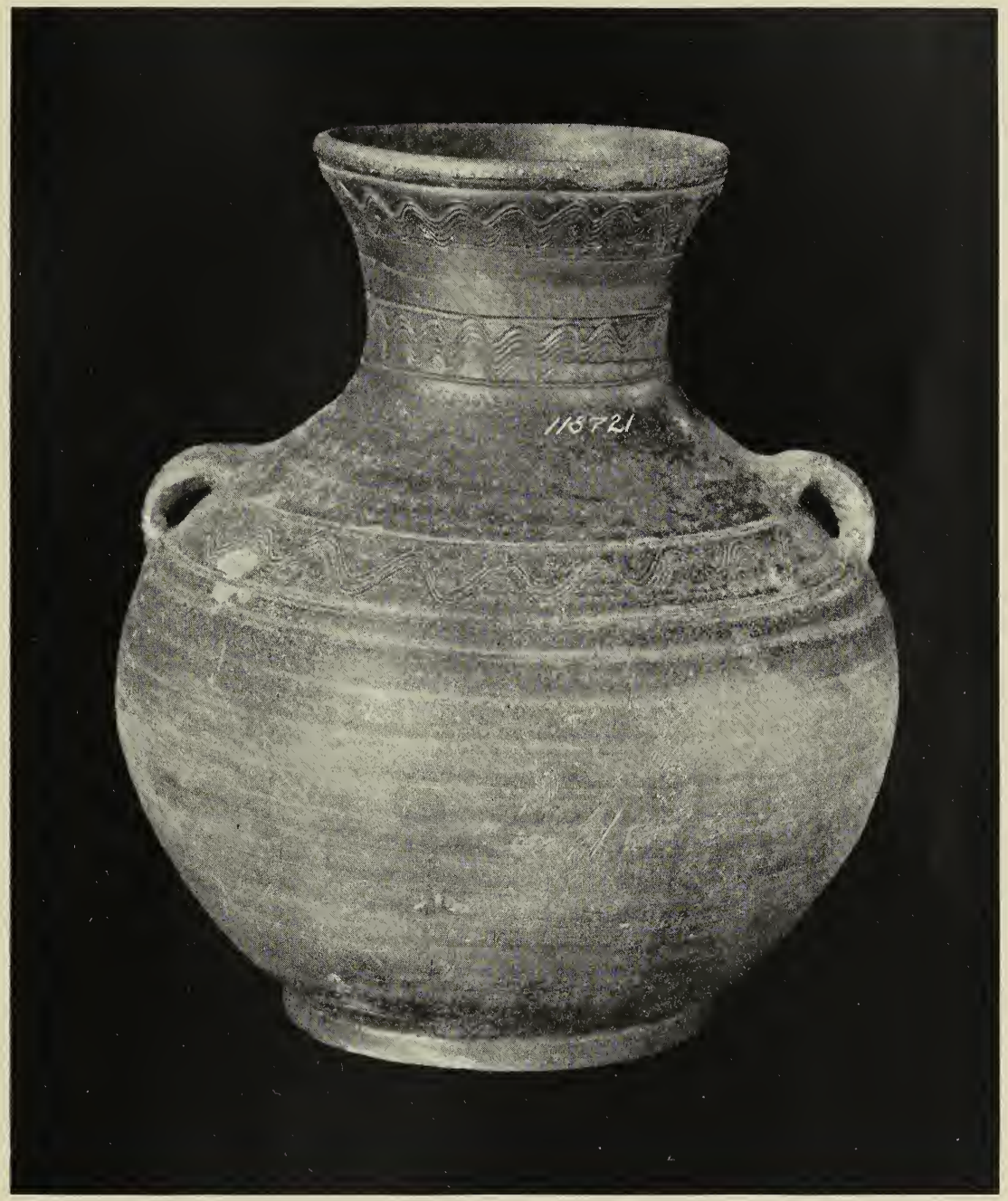

han porcelanous Vase. 


PLATE VII.

Han Porcelanous Pottery.

Large globular vase, in its medial portion and inside of the neck coated with a thin, but evenly distributed porcelanous glaze. Wave-band along upper rim, and a broader wave-band of bolder design around the neck. The loop handles show a fish-bone design incised under the glaze. Flat bottom without rim. Of almost perfect workmanship.

Third century A.D.

Height, $34.8 \mathrm{~cm}$.

Cat. No. 118722 . 


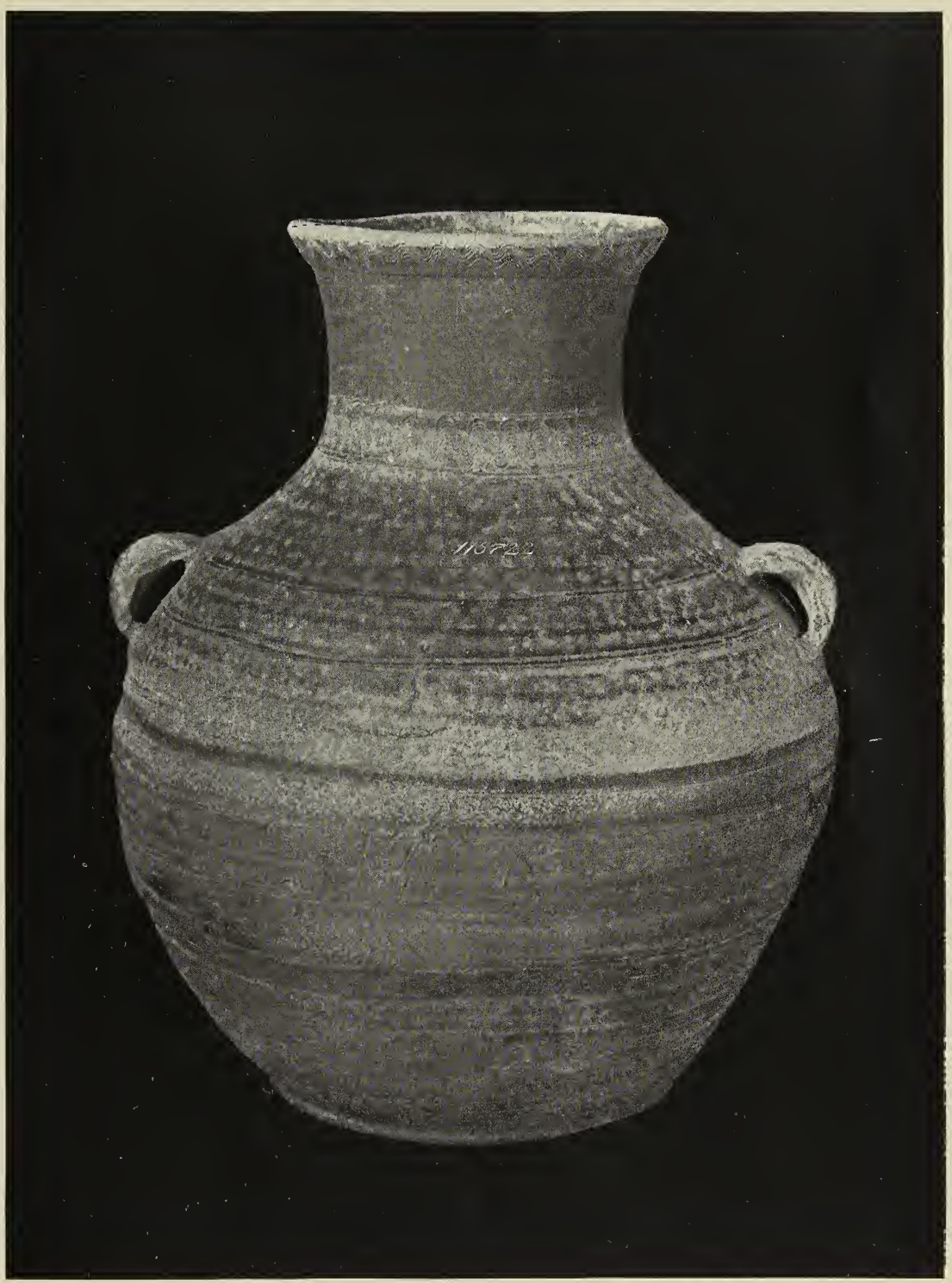

han porcelanous Vase. 


Plate VIII.

Han Porcelanous Potrery.

Large vase with asymmetrical neck, apparently turned out by an unskilled potter. A large piece is broken out of the neck (found in this condition) on the side of the vase not shown in the illustration. The glaze, covering only the middle portion, is thick and unevenly applied, in some instances forming small warts or globules. Decorated with two wave-bands. Loop handles with fish-bone design. The bottom is raised on a rim $\mathrm{I} \mathrm{cm}$ high.

Third century A.D.

Height, $27.2 \mathrm{~cm}$. Cat. No. I 18724. 


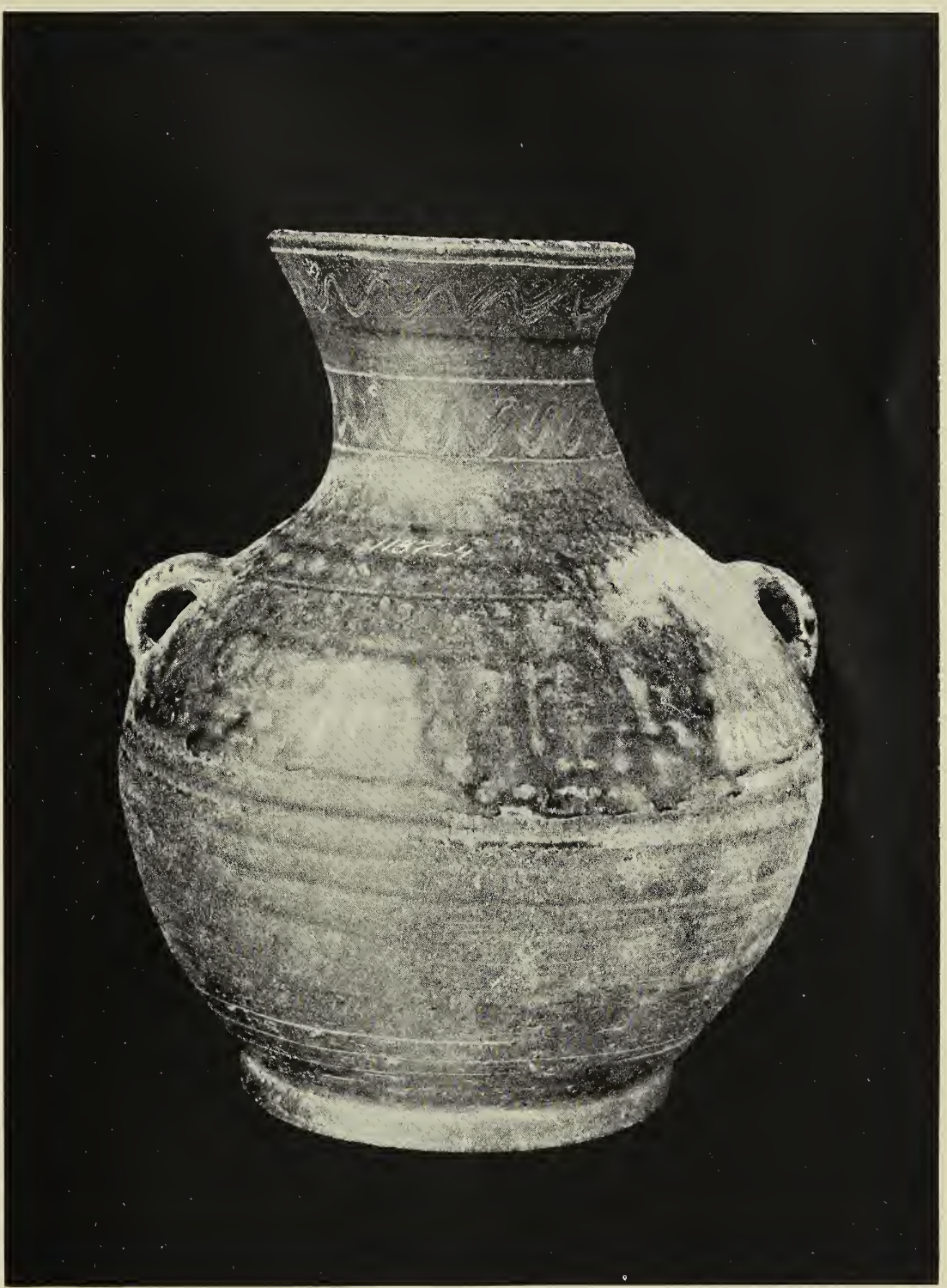

han porcelanous Vase. 




\section{Plate iX.}

Han Porcelanous Pottery.

Large ovoid vase of good proportions, of light-reddish clay, glazed in the medial portion and in the interior of the neck, exterior of neck and base being coated with a brown slip. Two wave-bands. Loop-handles with leaf design of raised lines.

Third century A.D.

Height, $35.6 \mathrm{~cm}$.

Cat. No. I 187 I9. 


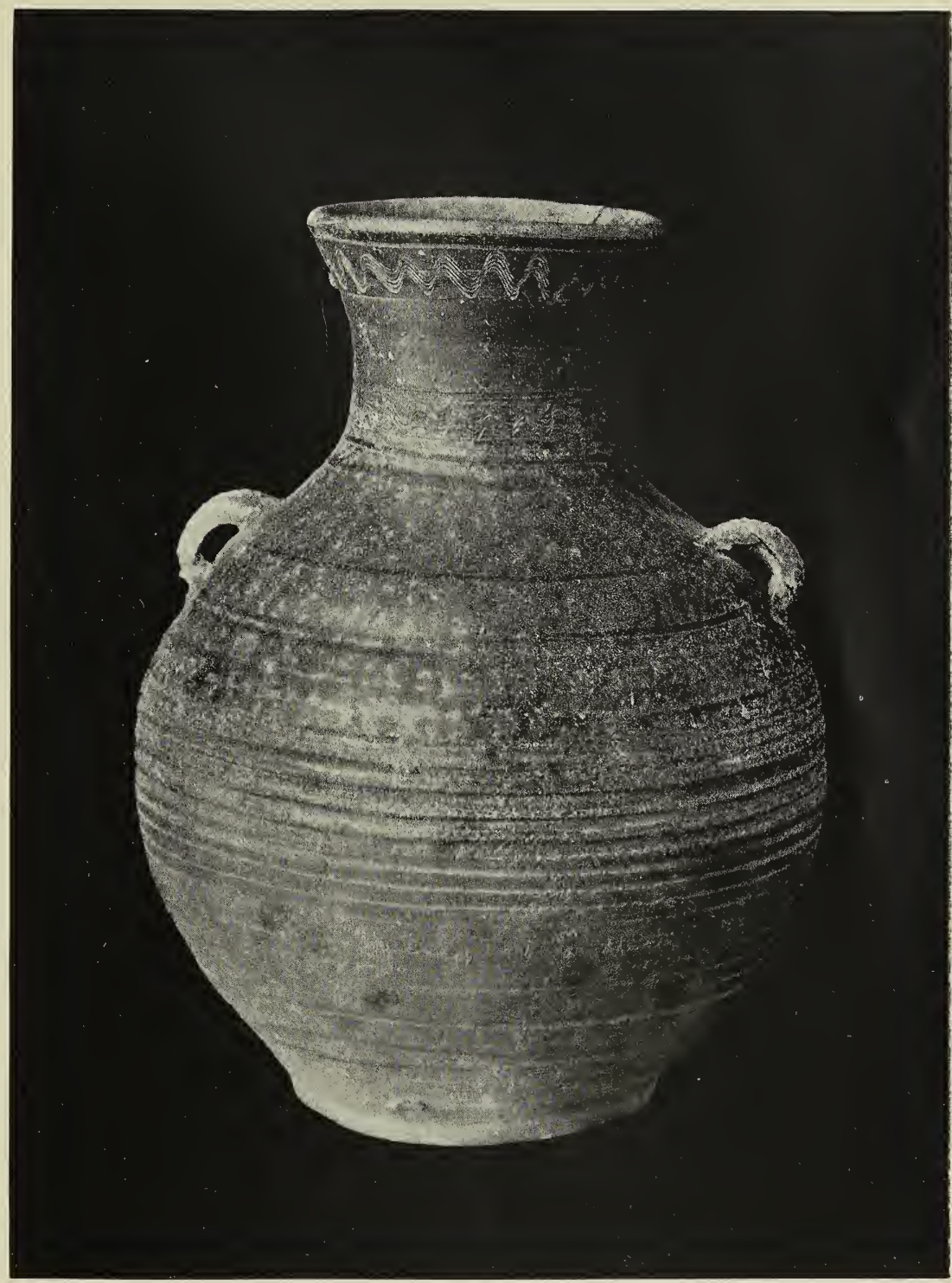

han Porcelanous Vase. 


Plate $X$.

\section{Han Porcelanous Pottery.}

Jar of the type lei 覆. The bottom inside is glazed. The exterior is glazed as far down as the middle of the body; the base is coated with a brown-red slip. The handles are glazed only in their upper portions. A wave-band is run over the shoulders under the glaze, passing below the loop handles. The latter are wrought into the appearance of an elaborate animal-head of similar style, that is moulded in relief on the body of the vessel.

\section{Third century A.D.}




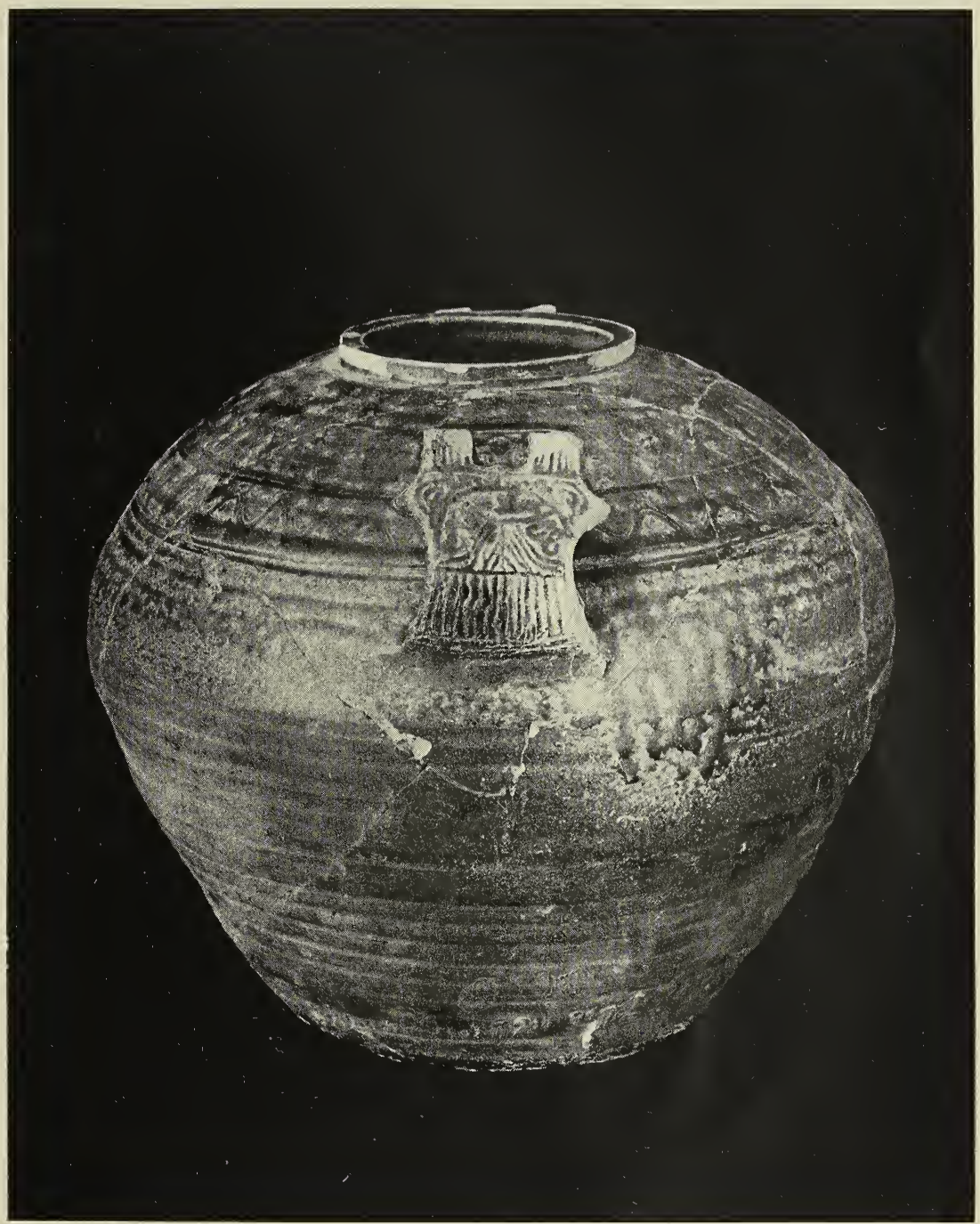

HAN FORCELANOUS JAR. 




\section{PLATE XI.}

Chinese Potter's Wheel (see p. I62).

From kiln near Peking. Table of clay, $52 \mathrm{~cm}$ in diameter on the top, $60 \mathrm{~cm}$ across the opening below.

In the collections of the American Museum of Natural History, New York. Secured by the writer in 1903 .

$$
\text { Height, r.24 m. } \quad \text { Cat. No. } \frac{70}{12797} \text {. }
$$




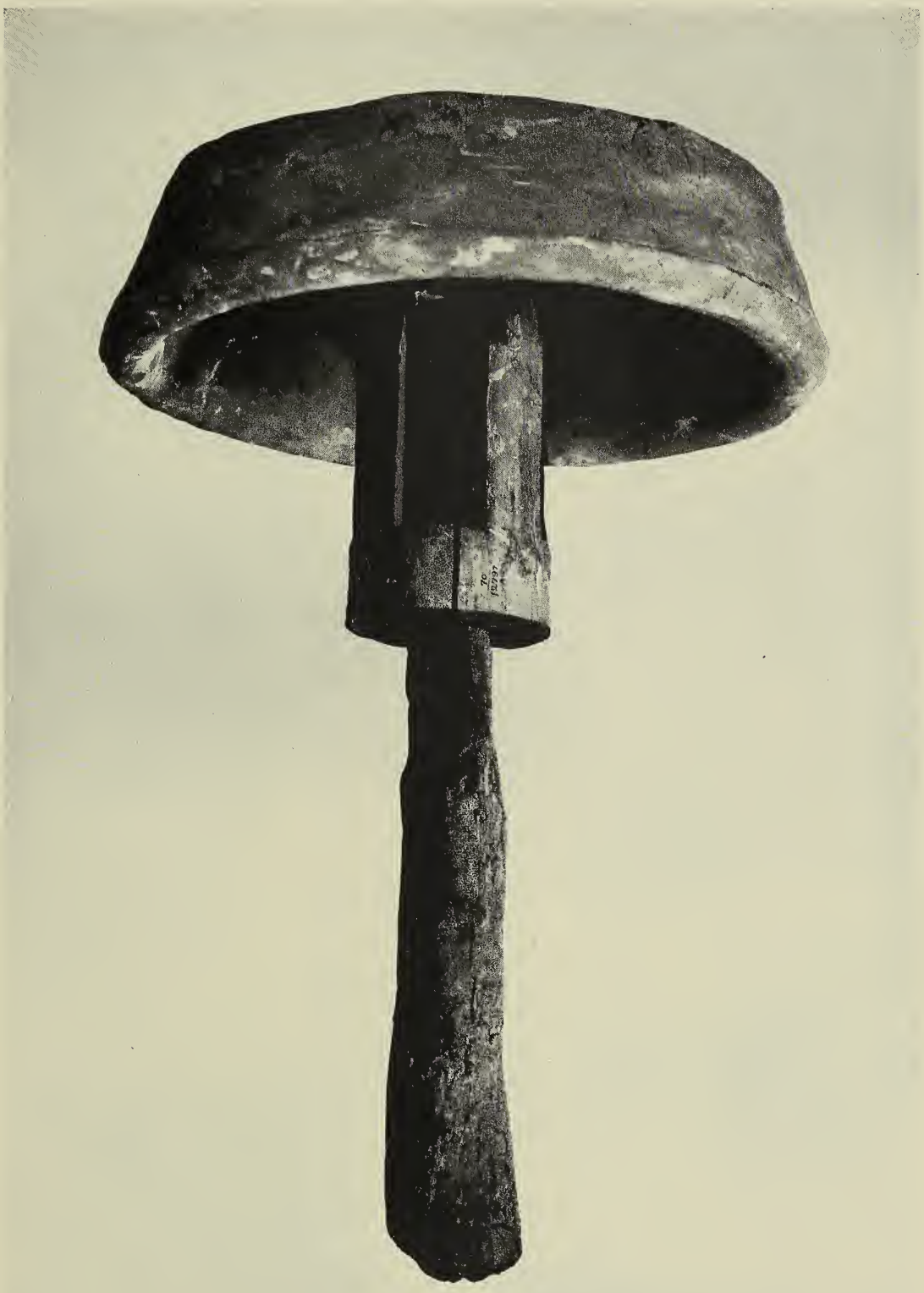

Chinese PotTer's WheEl of Clay. 


Plate XII.

Chinese Potter's Wheel (see p. 162).

From kiln near Peking. The table is formed by a heavy stone disk $60 \mathrm{~cm}$ in diameter and $9 \mathrm{~cm}$ thick. On top of it is placed a small wooden table, $35 \mathrm{~cm}$ in diameter. The main shaft is of wood and $87 \mathrm{~cm}$ high; the two wooden side-supports are $37 \mathrm{~cm}$ in length.

In the collections of the American Museum of Natural History, New York. Secured by the writer in 1903.

Cat. No. $\frac{70}{12798}$. 


$$
\text { I] }
$$








SMITHSONIAN INSTITUTION LIBRARIES
||

\section{8}

